\title{
Sequential Transformation of Terminal Alkynes to \\ 1,3-Dienes by a Cooperative Cobalt-Pyridonate Catalyst
}

Xuewen Zhuang, ${ }^{\dagger}$ Jia-Yi Chen, ${ }^{\dagger \dagger}$ Zhuoyi Yang, ${ }^{\dagger}$ Mengjing Jia, ${ }^{\dagger}$ Chengjuan Wu, ${ }^{\dagger}$ Rong-Zhen Liao, ${ }^{* \dagger}$ Chen-Ho Tung, ${ }^{\dagger}$ and Wenguang Wang* ${ }^{\dagger}$

${ }^{\dagger}$ School of Chemistry and Chemical Engineering, Shandong University, 27 South Shanda Road, Jinan, 250100, China

${ }^{\dagger}$ School of Chemistry and Chemical Engineering, Huazhong University of Science and Technology, 1037 Luoyu Road, Wuhan, 430074, China

Email: wwg@sdu.edu.cn; rongzhen@hust.edu.cn

\section{Table of contents}

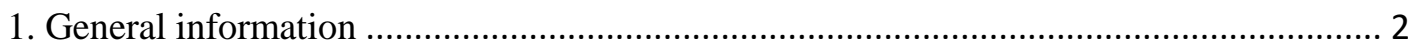

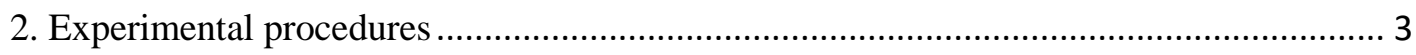

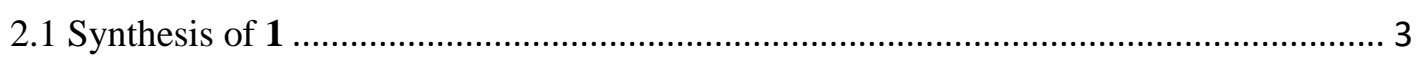

2.2 Catalytic homodimerization of terminal alkynes.......................................................... 4

2.3 Sequential catalysis from alkyne to diene. ……........................................................... 4

2.4 Catalytic cross-dimerization of terminal alkynes. .................................................... 4

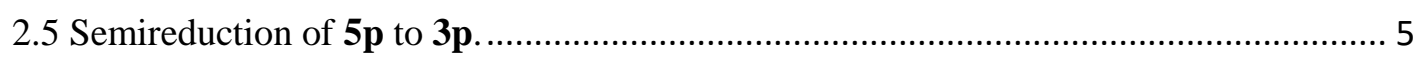

3. Time evolution of product ratio ( $E$-enyne vs $Z$-enyne) …........................................... 5

4. Stoichiometric reaction of complex 1 with arylacetylene. ............................................ 6

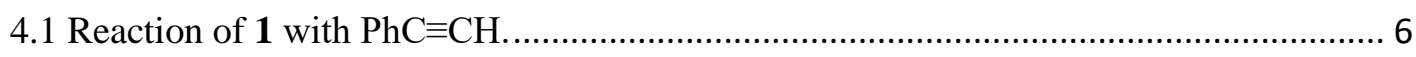

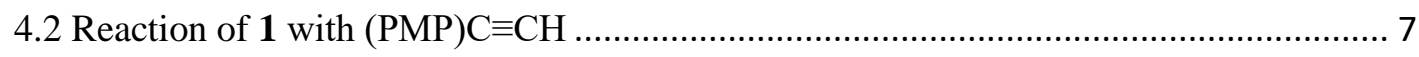

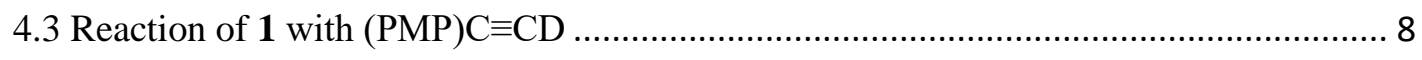

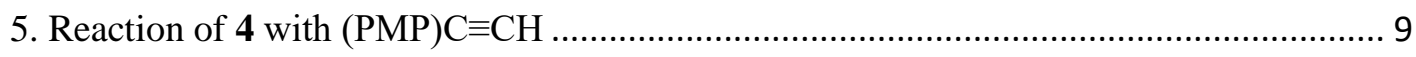

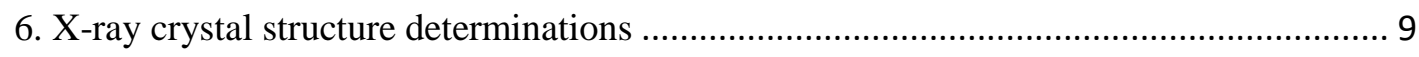

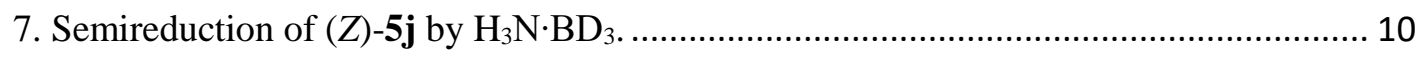

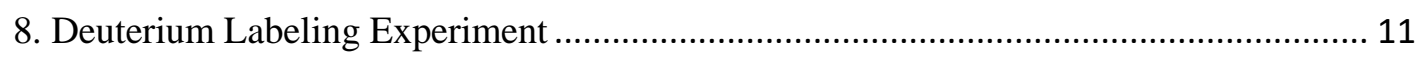

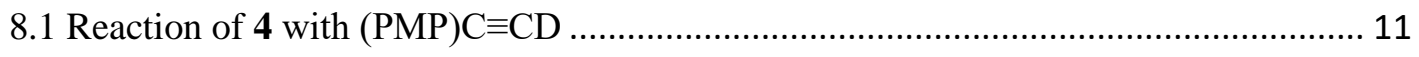

8.2 Synthesis of $(E)-\mathrm{PhC} \equiv \mathrm{C}-\mathrm{CD}=\mathrm{CDPh}$ and deuterated dienes................................... 12 


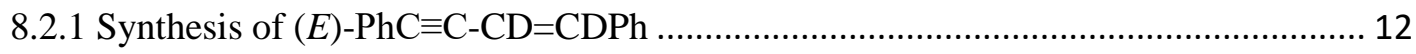

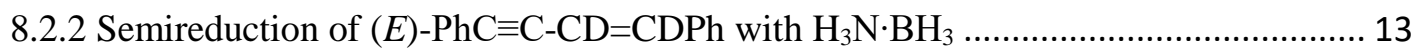

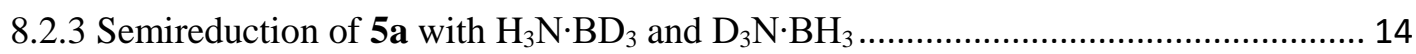

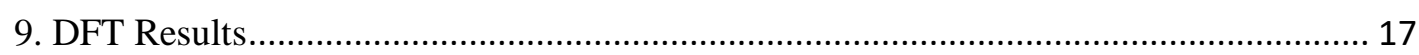

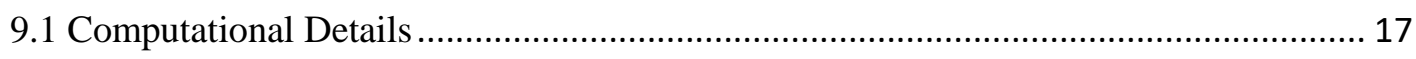

9.2 Relaxed potential energy surface scan for the side-on coordination of an alkyne to Co.

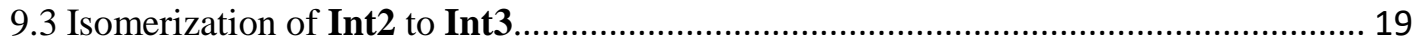

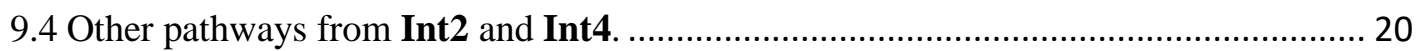

9.5 Gibbs energy diagram for the dimerization of phenylacetylene catalyzed by 1 at the

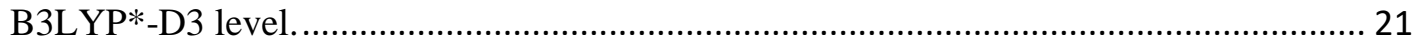

9.6 Gibbs energy diagram for Semireduction of 5a at the B3LYP*-D3 level. .................. 21

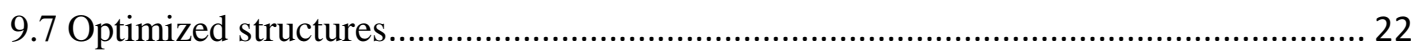

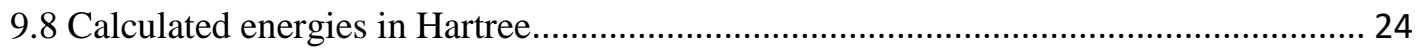

10. Characterization data of $(E)$-enynes and 1,3-dibutadienes ....................................... 26

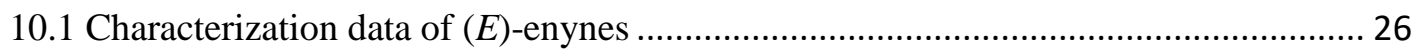

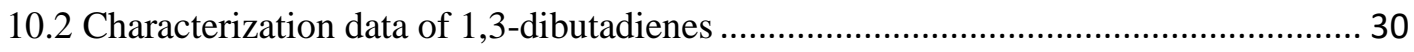

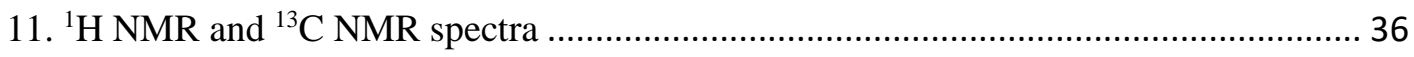

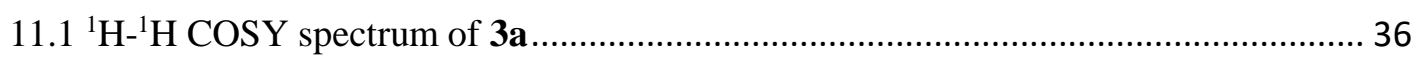

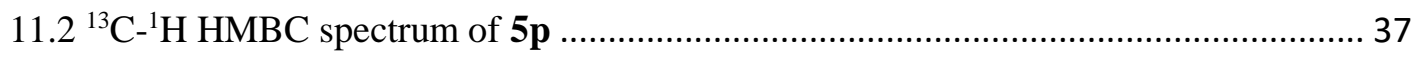

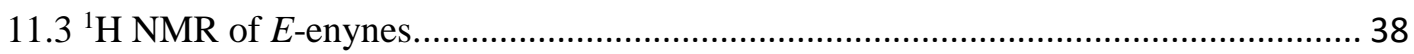

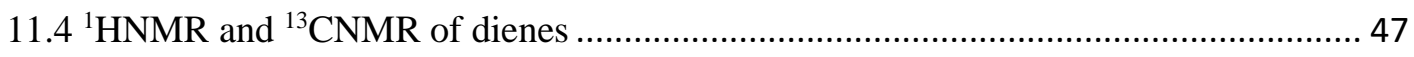

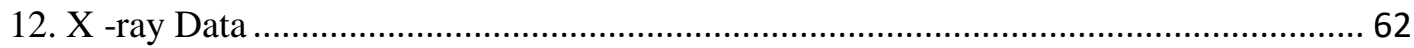

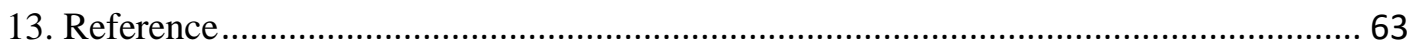

\section{General information}

All reactions were performed in flame-dried glassware using standard Schlenk techniques or in a glovebox under nitrogen atmosphere. Toluene, hexane, tetrahydrofuran and dichloromethane were dried and degassed by Solvent Purification Systems (Innovative Technology). $\mathrm{CDCl}_{3}$ was dried with $4 \AA$ molecular sieves. 
Tetraethylsilane, all alkyne substrates were purchased from commercial suppliers and used as received. The 6-((diphenylphosphanyl) methyl) pyridin-2(1H)-one $\left(1,6-\mathrm{Ph}_{2} \mathrm{PC}_{5} \mathrm{H}_{4} \mathrm{NOH}\right)$ were prepared according to reported procedures. ${ }^{1}$ Chemical shifts for ${ }^{1} \mathrm{H}$ and ${ }^{13} \mathrm{C}$ NMR spectra were referred to residual solvent resonances and are reported relative to tetramethylsilane.

\section{Experimental procedures}

\subsection{Synthesis of 1}

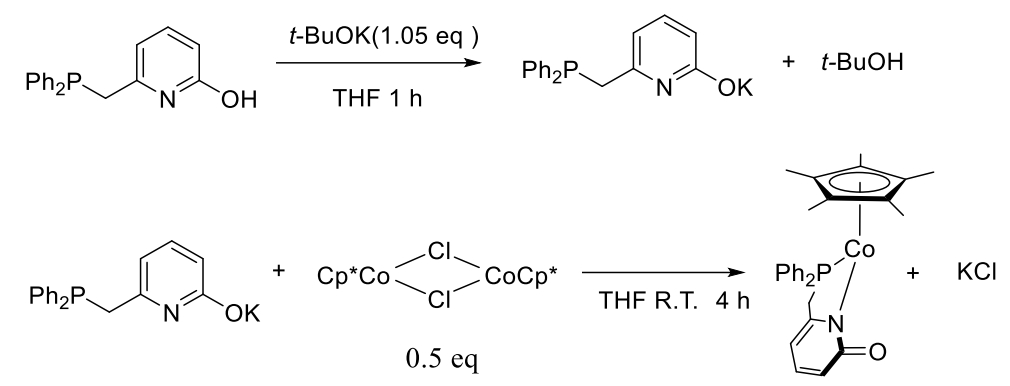

$t$ - $\mathrm{BuOK}(84 \mathrm{mg}, 0.75 \mathrm{mmol})$ was added to a solution of $1,6-\mathrm{Ph}_{2} \mathrm{PC}_{5} \mathrm{H}_{4} \mathrm{NOH}(200$ $\mathrm{mg}, 0.68 \mathrm{mmol})$ in THF $(40 \mathrm{~mL})$ at room temperature. After it was stirred for $1 \mathrm{~h}$, $[\mathrm{Cp} * \mathrm{CoCl}]_{2}(156 \mathrm{mg}, 0.34 \mathrm{mmol})$ was added, and the reaction was stirred at room temperature for $3 \mathrm{~h}$. The mixture turned from colorless to orange red. The solvent was removed under vacuum, and the residue was extracted with toluene $(3 \times 15 \mathrm{~mL})$. Remove the solvent and wash the residue with hexane for several times to obtain brown yellow power. After recrystallization from ether at $-30{ }^{\circ} \mathrm{C}$, complex $\mathbf{1}$ was obtained as brown yellow microcrystals. Yield: $270 \mathrm{mg}(82 \%)$. ESI-MS: calcd for $[1]^{+}$, 486.1392; found. 486.1382. Anal. Calcd for $\mathrm{C}_{28} \mathrm{H}_{30} \mathrm{CoNOP}$ : C, 69.13; H, 6.22; N, 2.88. Found: $\mathrm{C}, 69.05 ; \mathrm{H}, 6.35 ; \mathrm{N}, 2.83 . \mu_{\mathrm{eff}}=2.24 \mu_{\mathrm{B}}\left(\mathrm{C}_{6} \mathrm{D}_{6}, 25^{\circ} \mathrm{C}\right)$. 


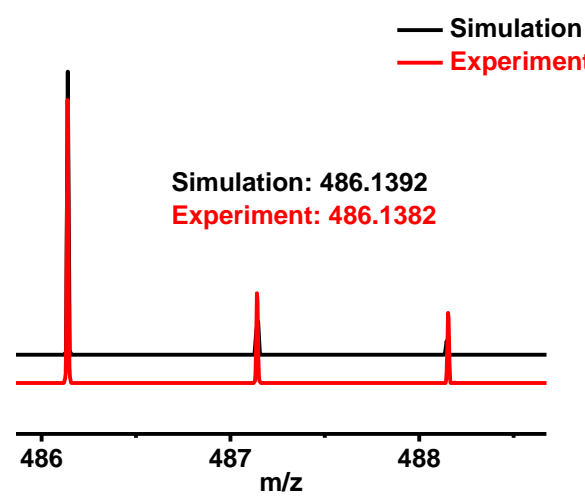

Figure S1. ESI-MS of complex 1. Result: calcd for 1, 486.1392; found, 486.1382.

\subsection{Catalytic homodimerization of terminal alkynes.}

Complex 1 (5.8 $\mathrm{mg}, 0.0125 \mathrm{mmol})$, the alkyne substrate ( $0.4 \mathrm{mmol})$ were mixed in $0.5 \mathrm{~mL}$ THF in a $10 \mathrm{~mL}$ vial inside of a nitrogen glovebox. Tetraethylsilane $(10 \mu \mathrm{L}$, $0.053 \mathrm{mmol}$ ) was added as internal standard and the mixture was stirred at $40{ }^{\circ} \mathrm{C}$ for $12 \mathrm{~h}$. After cooling to room temperature, a NMR sample was prepared using $0.1 \mathrm{~mL}$ of the reaction mixture in $0.4 \mathrm{~mL}$ of $\mathrm{CDCl}_{3}$. The conversion and yield of the reaction were determined by ${ }^{1} \mathrm{H}$ NMR signals of the products compared to internal standard.

\subsection{Sequential catalysis from alkyne to diene.}

Complex 1 (11.6 mg, 0.024mmol) was dissolved in $1 \mathrm{~mL}$ of THF in a vial inside a nitrogen-glove box. The alkyne substrate $(0.8 \mathrm{mmol})$ was added using a microsyringe. The reaction was stirring at $40{ }^{\circ} \mathrm{C}$ for $12 \mathrm{~h}$. After the dimerization of alkynes, the vial was transferred to nitrogen-glove box. Ammonia borane (24.8mg, $0.8 \mathrm{mmol}$ ) was added in the vial. The reaction was stirring at $40{ }^{\circ} \mathrm{C}$ for $4 \mathrm{~h}$. The residue was purified by flash column chromatography on silica gel.

\subsection{Catalytic cross-dimerization of terminal alkynes.}

Complex 1 (8.73 mg, $0.018 \mathrm{mmol})$, the 2-ethynylnaphthalene (91.2mg, 0.6 mmol) and trimethylsilylacetylene $(295 \mu \mathrm{L}, 1.8 \mathrm{mmol})$ were mixed in $2 \mathrm{~mL}$ THF in a $10 \mathrm{~mL}$ vial inside of a nitrogen glovebox. The mixture was stirred at $40{ }^{\circ} \mathrm{C}$ for $24 \mathrm{~h}$. 
The crude product was purified by flash column chromatography with petroleum ether. Yield: $70.1 \mathrm{mg}(48 \%)$.

\subsection{Semireduction of $5 p$ to $3 p$.}

5p (50.0mg, 0.2mmol) and ammonia borane $(6.2 \mathrm{mg}, 0.2 \mathrm{mmol})$ was dissolved in THF added in a vial. The reaction was stirring at $40{ }^{\circ} \mathrm{C}$ for $4 \mathrm{~h}$. The crude product of 3o was purified by flash column chromatography on silica gel. Yield: $37.0 \mathrm{mg}$ (75\%).

\section{Time evolution of product ratio ( $E$-enyne vs $Z$-enyne)}
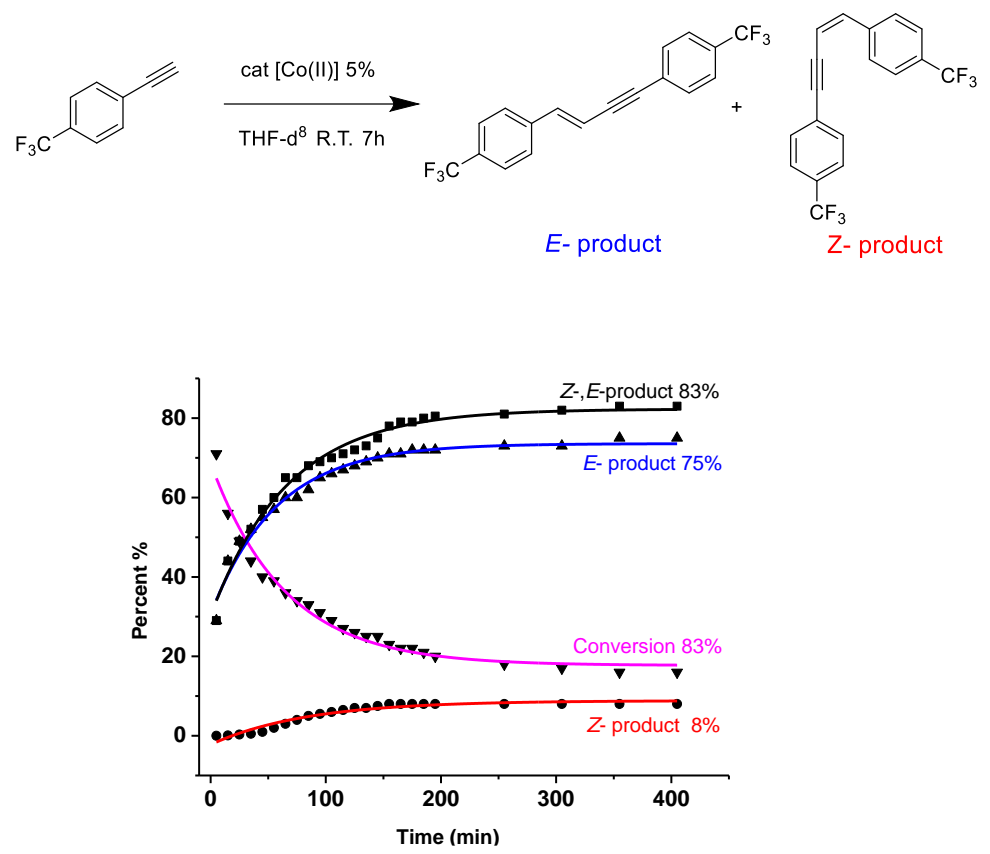

Figure S2. ${ }^{1} \mathrm{H}$ NMR kinetic plot of the dimerization of $\mathbf{2} \mathbf{j}$ catalyzed by $3 \mathrm{~mol} \%$ of $\mathbf{1}$, with tetraethylsilane as an internal standard. 

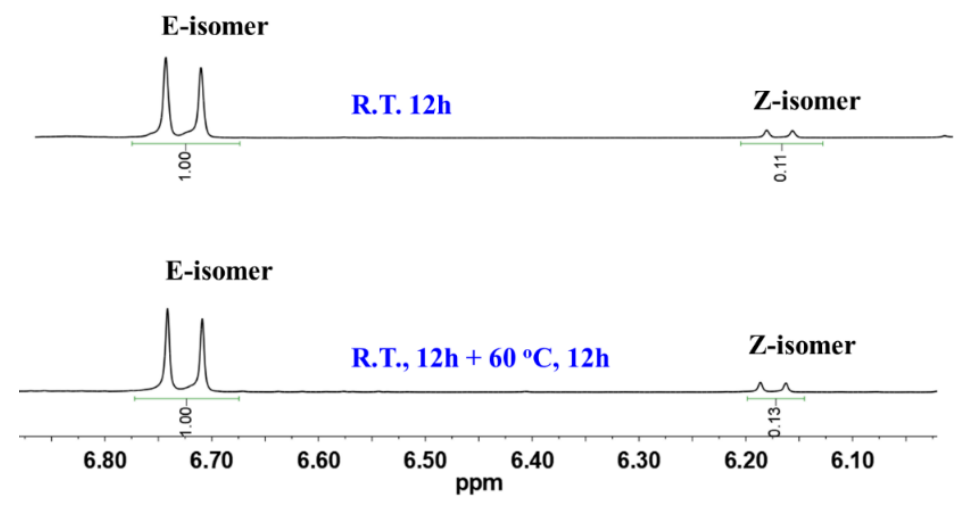

Figure S3. Conversion of $(E)$ - to $(Z)$-isomer a) room temperature for $12 \mathrm{~h}, \mathrm{~b}$ ) room temperature for $12 \mathrm{~h}$ and heating for $12 \mathrm{~h}$.

A $\mathrm{d}^{8}$-THF solution of tetraethylsilane $(10 \mu \mathrm{L}, 0.053 \mathrm{mmol})$ and complex 1 $(5.8 \mathrm{mg}, 0.012 \mathrm{mmol})$ was added in a J. Young NMR tube inside a glovebox. Then 1-ethynyl-4-(trifluoromethyl)benzene $(\mathbf{2 j})(66 \mu \mathrm{L}, 0.4 \mathrm{mmol})$ was added to the $\mathrm{J}$. Young NMR tube of the resulting solution which was put in a pre-cooled bath at $-30{ }^{\circ} \mathrm{C}$ under $\mathrm{N}_{2}$ atmosphere. The tube was sealed immediately, quickly removed from the glovebox, and place into an ethyl acetate/liquid nitrogen bath. It was well shaken to mix up all the components and immediately placed in the NMR probe that was pre-adjusted to $298.1 \mathrm{~K}$. The product concentration was monitored at $60 \mathrm{~s}$ intervals for $7 \mathrm{~h}$ to determine the initial reaction rate. After monitored sample by ${ }^{1}$ HNMR we placed the J. Young NMR tube at room temperature for $12 \mathrm{~h}$, then heated the sample at $60^{\circ} \mathrm{C}$ for $12 \mathrm{~h}$, the ratio of $E$-isomer and $Z$-isomer remain at 10:1.

\section{Stoichiometric reaction of complex 1 with arylacetylene.}

\subsection{Reaction of 1 with $\mathrm{PhC} \equiv \mathrm{CH}$.}

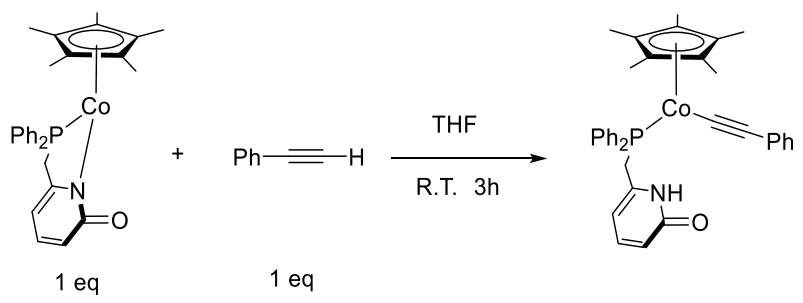




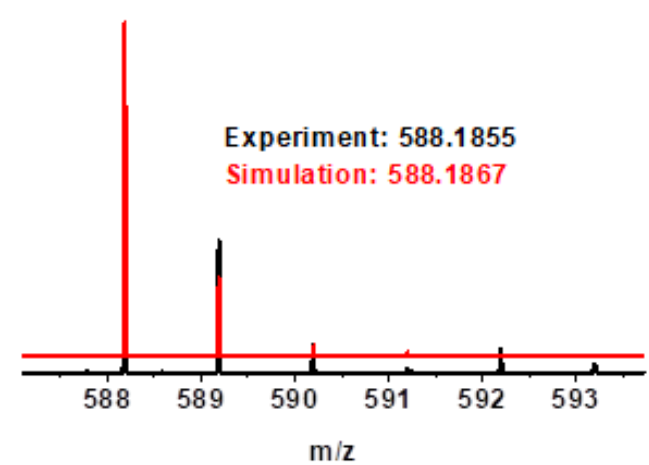

Figure S4. ESI-MS of Int1. Result: calcd for Int1, 588.1861; found, 588.1850.

Complex 1 (48 mg, $0.10 \mathrm{mmol}$ ) was dissolved in THF in a vial. Phenylacetylene (11 $\mu \mathrm{L}, 0.10 \mathrm{mmol}$ ) was added into the THF solution, the color turned to dark brown. The reaction was stirred at room temperature for $3 \mathrm{~h}$, the mixture filtered through a short pad of celite and the solvent was removed under vacuum. The crude product was washed with hexane to obtain pure product. Yield: $49 \mathrm{mg}$ (85\%). ESI-MS: calcd for $[1]^{+}, 588.1861$; found. 588.1850. Anal. Calcd for $\mathrm{C}_{36} \mathrm{H}_{36} \mathrm{CoNOP}$ : C, 73.46; H, 6.17, N, 2.38. Found: C, 73.41; H, 6.19; N, 2.39.

\subsection{Reaction of 1 with $(\mathrm{PMP}) \mathrm{C} \equiv \mathrm{CH}$}
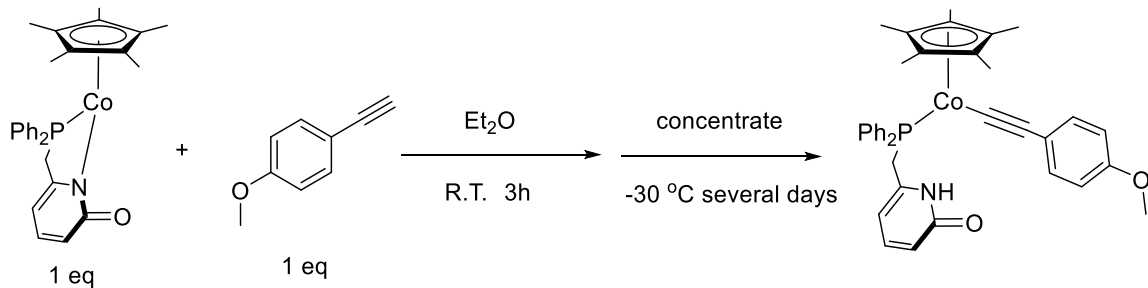

Complex 1 (48 mg, $0.10 \mathrm{mmol}$ ) was dissolved in $\mathrm{THF}$ in a vial. 1-ethynyl-4-methoxybenzene ( $13 \mu \mathrm{L}, 0.10 \mathrm{mmol})$ was added into the THF solution, and the color turned to dark green. The reaction was stirred at room temperature for $3 \mathrm{~h}$, and the mixture was filtered through a short pad of celite and the solvent was removed under vacuum. The crude product was washed with hexane to obtain $\mathrm{Cp}^{*} \mathrm{Co}(\mathrm{C} \equiv \mathrm{C}(\mathrm{PMP}))\left[\left(\mathrm{Ph}_{2} \mathrm{PCH}_{2}\right) \mathrm{C}_{5} \mathrm{H}_{4} \mathrm{NH}(\mathrm{O})\right]$ (4). Diethyl ether solution of 4 was stored at $-30{ }^{\circ} \mathrm{C}$ to provide dark green crystals. Yield: $49 \mathrm{mg}(80 \%)$. ESI-MS: calcd 
for $[4]^{+}, 618.1967$; found. 618.1952. Anal. Calcd for $\mathrm{C}_{37} \mathrm{H}_{38} \mathrm{CoNO}_{2} \mathrm{P}: \mathrm{C}, 71.84 ; \mathrm{H}$, 6.19, N, 2.26. Found: C, 71.75; H, 6.29; N, 2.23. $\mu_{\mathrm{eff}}=2.46 \mu_{\mathrm{B}}\left(\mathrm{C}_{6} \mathrm{D}_{6}, 25^{\circ} \mathrm{C}\right)$.

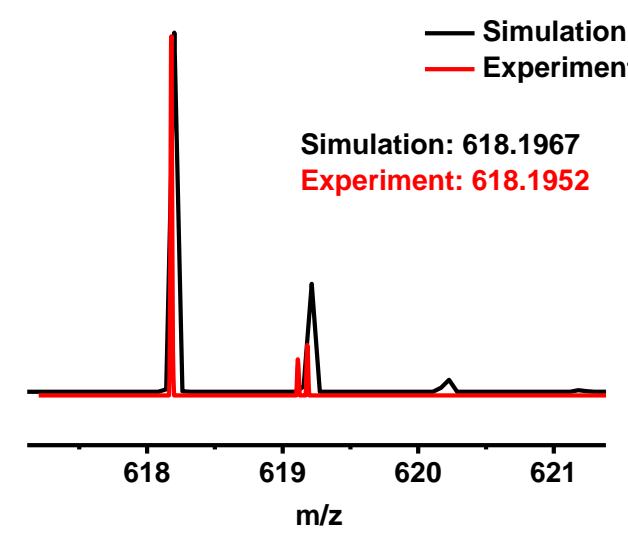

Figure S5. ESI-MS of complex 4. Result: calcd for 4, 618.1967; found, 618.1952.

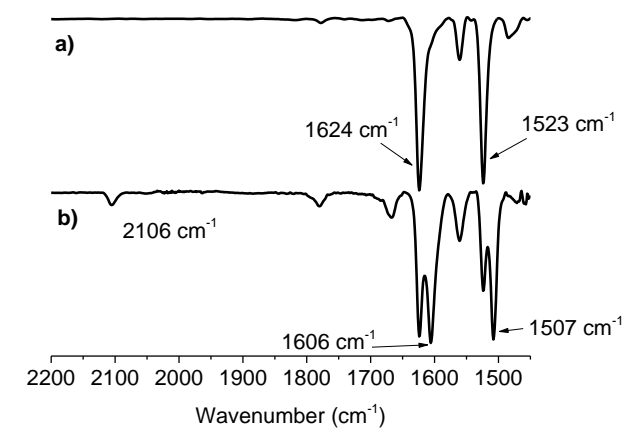

Figure S6. IR spectra ( $v_{\mathrm{CO}}$ region) of (a) 1, (b) 4 in THF solution. Results: a) $v_{\mathrm{CO}}$ ( $\left.\left.\mathrm{cm}^{-1}, \mathrm{THF}\right), 1624 ; \mathrm{b}\right) v_{\mathrm{CO}}\left(\mathrm{cm}^{-1}, \mathrm{THF}\right), 1606$.

\subsection{Reaction of 1 with (PMP)C $\equiv C D$}
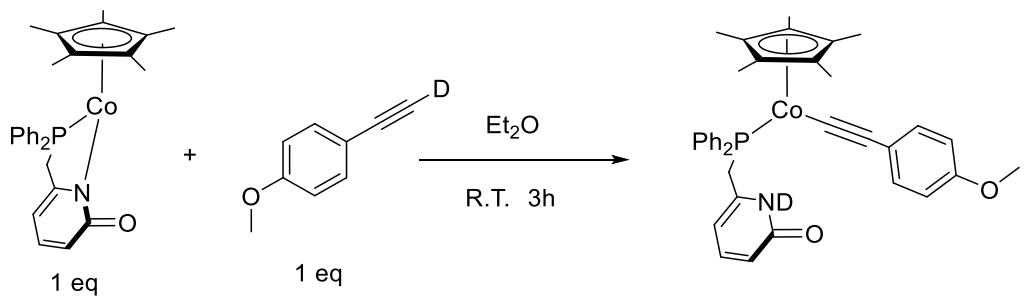

Complex 1 (48 mg, $0.10 \mathrm{mmol}$ ) was dissolved in THF in a vial. Deuterated 1-ethynyl-4-methoxybenzene $(13 \mu \mathrm{L}, 0.10 \mathrm{mmol})$ was added in the THF solution, and the color turned to dark green. The reaction was stirred at room temperature for $3 \mathrm{~h}$, 
then the mixture was filtered through a short pad of celite and the solvent was removed under vacuum. The crude product was washed with hexane to obtain compound 4'. Yield: $46 \mathrm{mg}$ (75\%). ESI-MS: calcd for [4'] ${ }^{+}, 619.2029$; found. 619.2017. Anal. Calcd for $\mathrm{C}_{37} \mathrm{H}_{37} \mathrm{DCoNO}_{2} \mathrm{P}: \mathrm{C}, 71.72$; H, 6.34, N, 2.26. Found: C, $71.75 ; \mathrm{H}, 6.36 ; \mathrm{N}, 2.24$.

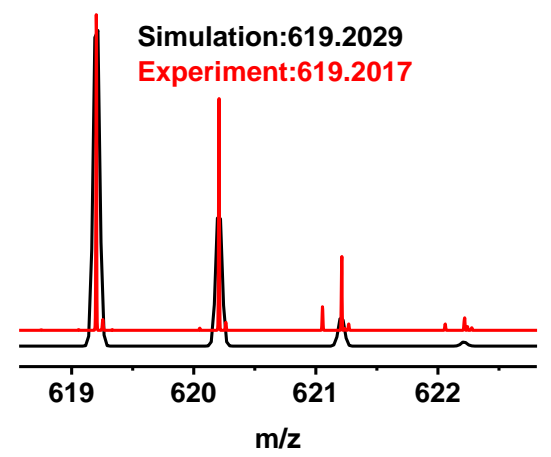

Figure S7. ESI-MS of complex 4'. Result: Calcd for 4', 619.2029; found, 619.2017.

\section{Reaction of 4 with $(\mathrm{PMP}) \mathrm{C} \equiv \mathrm{CH}$}

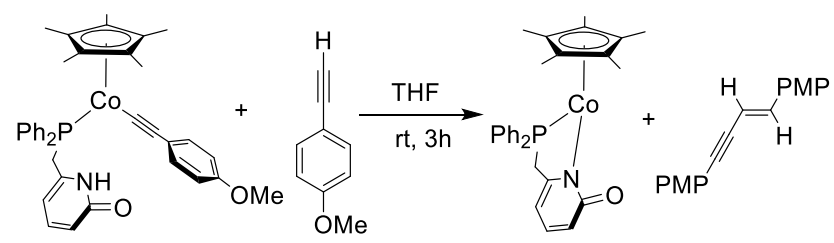

Complex 4 (31mg, $0.05 \mathrm{mmol})$ was dissolved in THF in a vial. 1-ethynyl-4-methoxybenzene $(6.5 \mu \mathrm{L}, 0.05 \mathrm{mmol})$ was then added into the solution. The reaction was stirred at room temperature for $3 \mathrm{~h}$, and the mixture was filtered through a short pad of celite in the air and the solvent was removed under vacuum. The residue was purified by flash column chromatography on silica gel (petroleum ether/ethyl acetate= 20:1). Yield: $7.8 \mathrm{mg}(60 \%)$.

\section{X-ray crystal structure determinations}

Crystals of $\quad \mathrm{Cp} * \mathrm{Co}(\mathrm{PNO}) \quad(\mathrm{PNO}=1,5-\mathrm{Ph} 2 \mathrm{PC} 6 \mathrm{H} 5 \mathrm{NO}) \quad$ (1) and $\mathrm{Cp} * \mathrm{Co}(\mathrm{C} \equiv \mathrm{C}(\mathrm{PMP}))\left[\left(\mathrm{Ph}_{2} \mathrm{PCH}_{2}\right) \mathrm{C}_{5} \mathrm{H}_{4} \mathrm{NH}(\mathrm{O})\right]$ (4) were obtained by recrystallization from diethyl ether at $-30 \quad{ }^{\circ} \mathrm{C}$. Crystals of 
(E)-2,2'-(but-1-en-3-yne-1,4-diyl)dinaphthalene (3m) were obtained from slow evaporation of a dichloromethane solution. Single crystals were coated with inert oil, placed under streaming nitrogen in a Bruker Apex II CCD diffractometer (Mo Ka radiation, $\lambda=0.71073 \AA$ ) for 4. Rigaku Oxford Diffraction XtaLAB Synergy diffractometer equipped with a HyPix-6000HE area detector $(\mathrm{Cu} \mathrm{K \alpha}$ radiation, $\lambda=$ $1.54184 \AA$ ) for $\mathbf{1}$ and $\mathbf{3 m}$. The structure was solved using the charge-flipping algorithm, as implemented in the program SUPERFLIP ${ }^{2}$ and refined by full-matrix least-squares techniques against $F_{\mathrm{o}}{ }^{2}$ using the SHELXL program ${ }^{3}$ through the OLEX2 interface. ${ }^{4}$ Hydrogen atoms bonded to carbon were placed at calculated positions and refined isotropically by using a riding model. Both structures were examined using the Addsym subroutine of PLATON ${ }^{5}$ to ensure that no additional symmetry could be applied to the models. Crystallographic and experimental details of the structure determination are summarized in Table S1-S3. CCDC 1893491-1893493 contain the supplementary crystallographic data for $\mathbf{1}, \mathbf{4}, \mathbf{3 m}$. These data are provided free of charge by The Cambridge Crystallographic Data Centre.

\section{Semireduction of (Z)-5j by $\mathrm{H}_{3} \mathrm{~N} \cdot \mathrm{BD}_{3}$.}

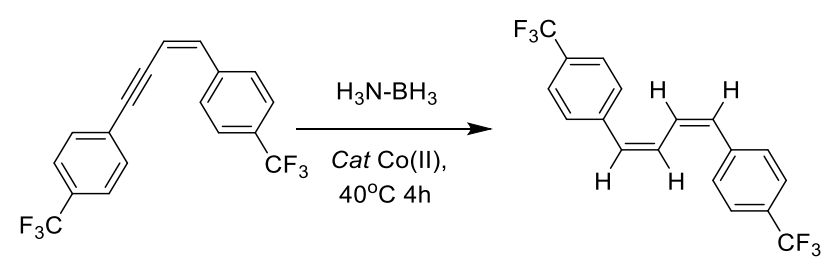

Byproduct of dimerization of 1-ethynyl-4-(trifluoromethyl)benzene was isolated and characterized as (Z)-4,4'-(but-1-en-3-yne-1,4-diyl)bis((trifluoromethyl)benzene). Complex $1(5.8 \mathrm{mg}, 0.012 \mathrm{mmol})$ was dissolved in $0.5 \mathrm{~mL}$ of THF in a $10 \mathrm{ml}$ vial inside a nitrogen-glove box. The (Z)-4,4'-(but-1-en-3-yne-1,4-diyl) bis((trifluoromethyl) benzene) $(68 \mathrm{mg}, 0.2 \mathrm{mmol})$ and ammonia borane $(6.2 \mathrm{mg}, 0.2$ mmol) were added. The reaction was stirred at $40{ }^{\circ} \mathrm{C}$ for $4 \mathrm{~h}$. The residue was purified by flash column chromatography on silica gel (petroleum ether). Yield: 41mg (60\%). 


\section{Deuterium Labeling Experiment}

\subsection{Reaction of 4 with $(\mathrm{PMP}) \mathrm{C} \equiv \mathrm{CD}$}

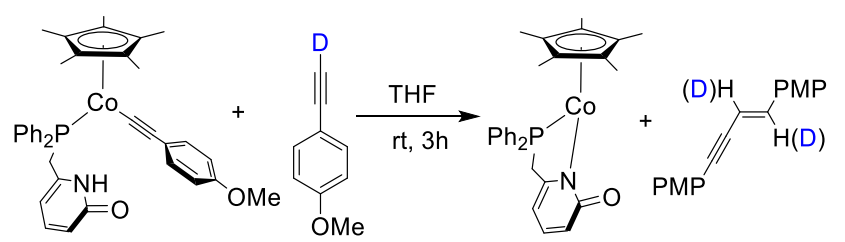

Complex 4 (31mg, $0.05 \mathrm{mmol})$ was dissolved in THF in a vial. Deuterated 1-ethynyl-4-methoxybenzene $(6.5 \mu \mathrm{L}, 0.05 \mathrm{mmol})$ was added into the THF solution. The reaction was stirred at room temperature for $3 \mathrm{~h}$, the mixture filtered through a short pad of celite in the air and the solvent was removed under vacuum. The residue was purified by flash column chromatography on silica gel (petroleum ether/ethyl acetate $=20: 1)$. Yield: $9.4 \mathrm{mg}(71 \%)$.

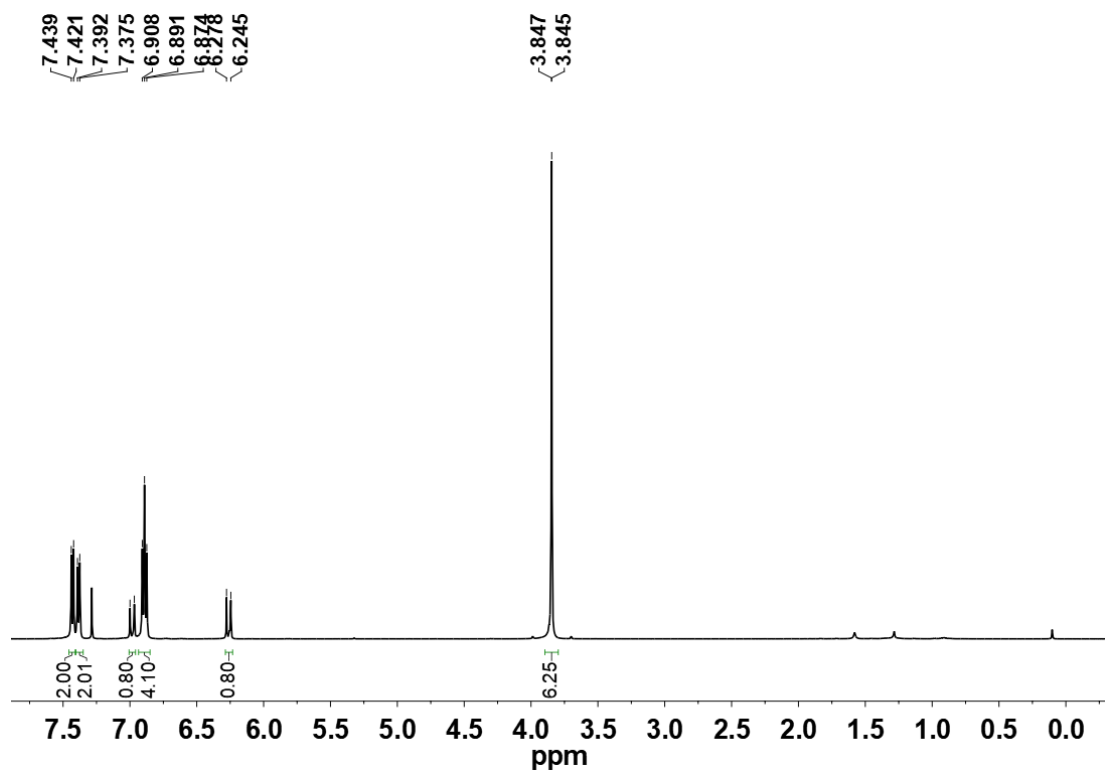

Figure S8. ${ }^{1} \mathrm{H}$ NMR spectrum of $(E)-(\mathrm{PMP}) \mathrm{C} \equiv \mathrm{C}-\mathrm{CH}(\mathrm{D})=\mathrm{CH}(\mathrm{D})(\mathrm{PMP})$ in $\mathrm{CDCl}_{3}$. 


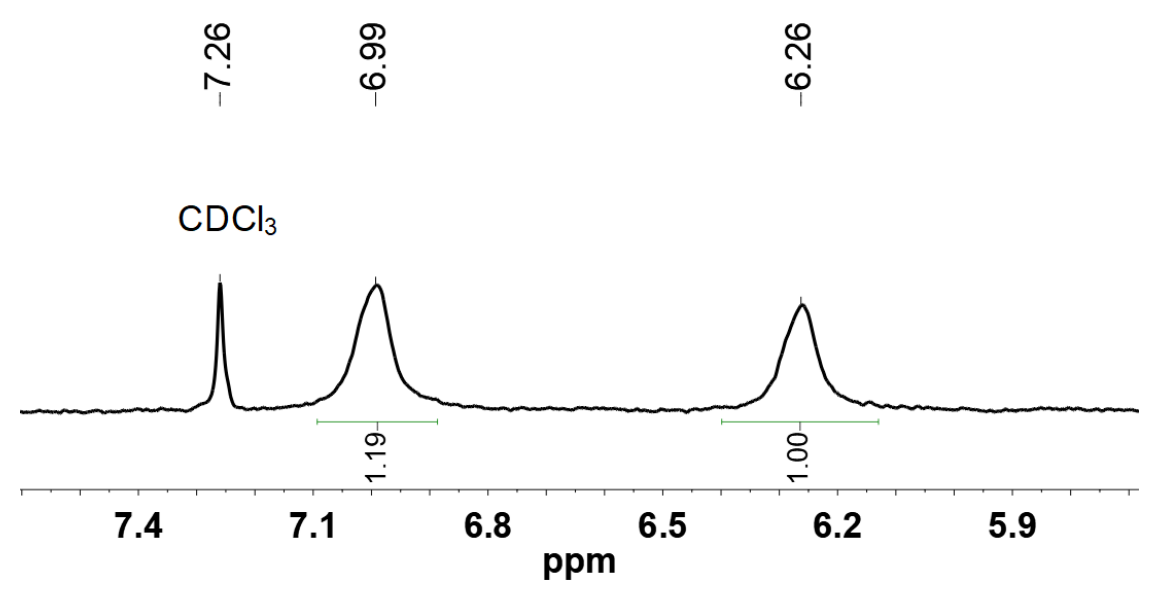

Figure S9. ${ }^{2} \mathrm{H}$ NMR spectrum of $(E)-(\mathrm{PMP}) \mathrm{C} \equiv \mathrm{C}-\mathrm{CH}(\mathrm{D})=\mathrm{CH}(\mathrm{D})(\mathrm{PMP})$ in $\mathrm{CDCl}_{3}$.

8.2 Synthesis of $(E)-\mathrm{PhC} \equiv \mathrm{C}-\mathrm{CD}=\mathrm{CDPh}$ and deuterated dienes.

\subsubsection{Synthesis of $(E)-P h C \equiv C-C D=C D P h$}

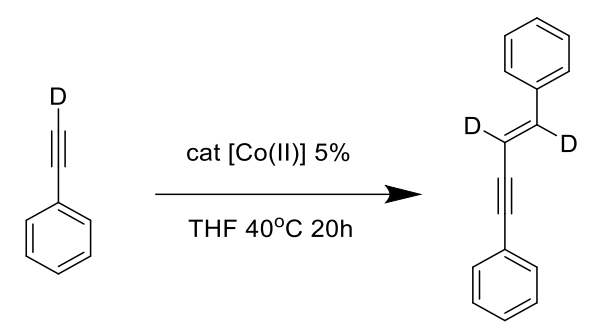

Complex 1 (5.8mg, 0.012mmol), the deuterated phenylacetylene ( $44 \mu \mathrm{L}$, $0.4 \mathrm{mmol}$ ) were mixed in $0.5 \mathrm{~mL}$ THF in a $10 \mathrm{~mL}$ vial inside of a nitrogen glovebox. Tetraethylsilane $(10 \mu \mathrm{L}, 0.053 \mathrm{mmol})$ was added as internal standard and the mixture was stirred at $40^{\circ} \mathrm{C}$ for $12 \mathrm{~h}$. After cooling to room temperature, an NMR sample was prepared using $0.1 \mathrm{~mL}$ of the reaction mixture in $0.4 \mathrm{~mL}$ of $\mathrm{CDCl}_{3}$. The conversion and yield of the reaction were determined by ${ }^{1} \mathrm{HNMR}$ signals of the products compared to internal standard. 


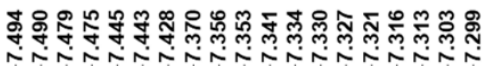

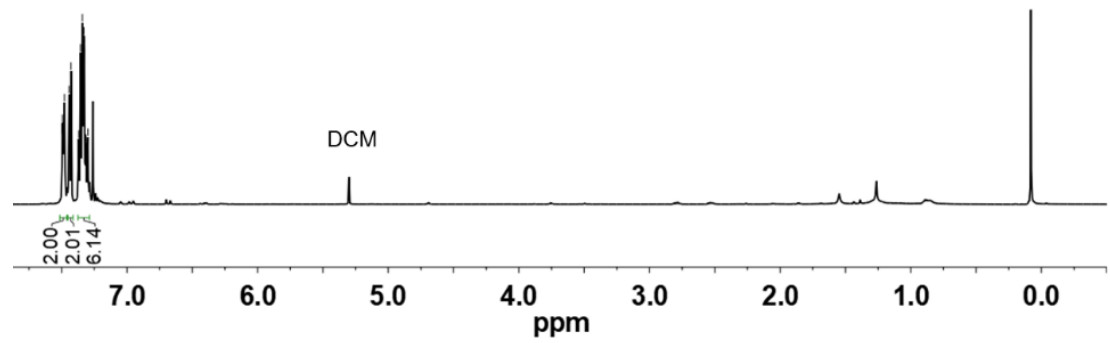

Figure S10. ${ }^{1} \mathrm{H}$ NMR spectrum of $d-5 \mathbf{a}$ in $\mathrm{CDCl}_{3}$.

\subsubsection{Semireduction of $(E)-\mathrm{PhC} \equiv \mathrm{C}-\mathrm{CD}=\mathrm{CDPh}$ with $\mathrm{H}_{3} \mathrm{~N} \cdot \mathrm{BH}_{3}$}

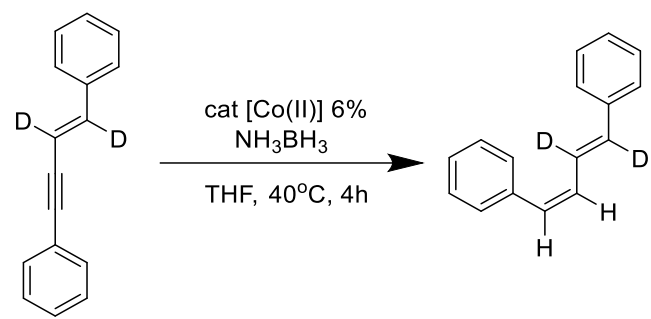

Complex $1(5.8 \mathrm{mg}, 0.012 \mathrm{~mol})$ were dissolved in $0.5 \mathrm{~mL}$ of THF in a $10 \mathrm{ml}$ vial inside a nitrogen-glove box. The $(E)-\mathrm{PhC} \equiv \mathrm{C}-\mathrm{CD}=\mathrm{CDPh}(40.8 \mathrm{mg}, 0.2 \mathrm{mmol})$ and ammonia borane $(6.2 \mathrm{mg}, 0.2 \mathrm{mmol})$ were added in the vial. The reaction was stirred at $40{ }^{\circ} \mathrm{C}$ for $4 \mathrm{~h}$. The residue was purified by flash column chromatography on silica gel with petroleum ether. Yield: $30.1 \mathrm{mg}(73 \%) .{ }^{1} \mathrm{H}$ NMR $\left(500 \mathrm{MHz}, \mathrm{CDCl}_{3}\right) \delta$ 7.43-7.40 (m, 6H, ArH), 7.34-7.28 (m, 3H, ArH), 7.24 (d, $J=7.2 \mathrm{~Hz}, 1 \mathrm{H}, \mathrm{ArH}), 6.53(\mathrm{~d}, J=$ $11.4 \mathrm{~Hz}, 1 \mathrm{H}$, vinyl-H), 6.43 (d, $J=11.4 \mathrm{~Hz}, 1 \mathrm{H}$, vinyl-H). 


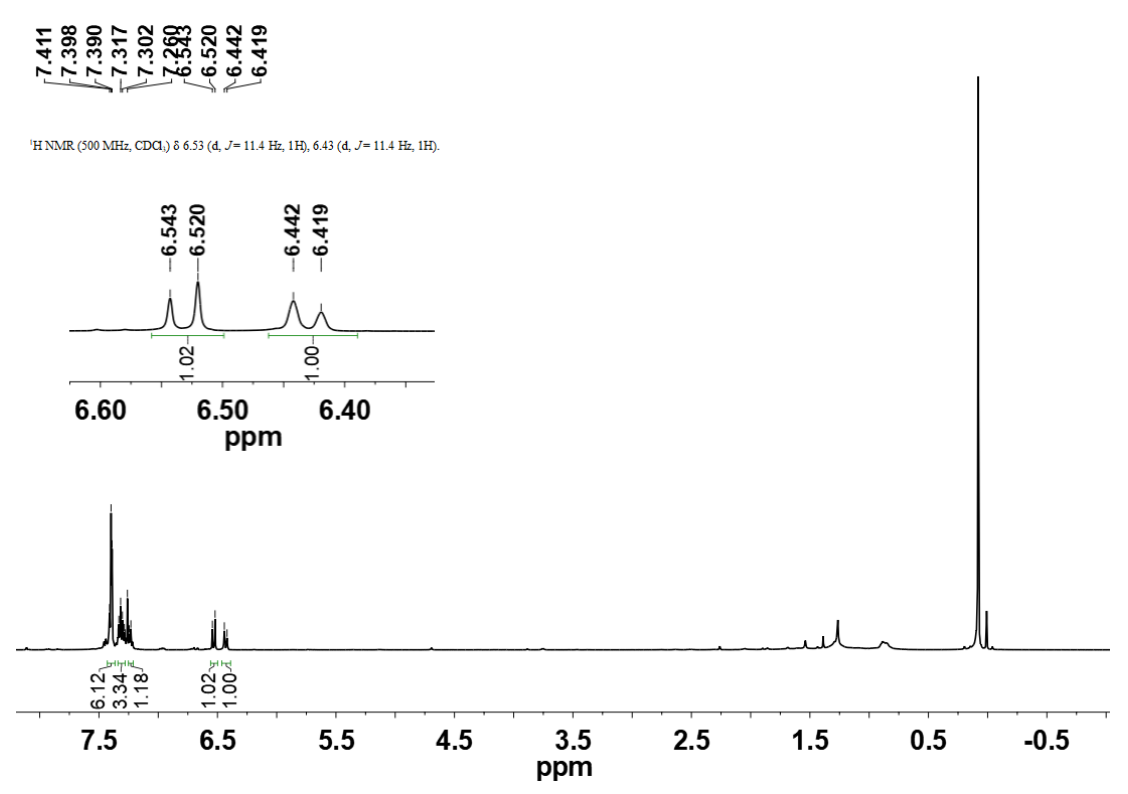

Figure S11. ${ }^{1} \mathrm{H}$ NMR spectrum of $(E, Z)-\mathrm{PhCH}=\mathrm{CH}-\mathrm{CD}=\mathrm{CDPh}$ in $\mathrm{CDCl}_{3}$.

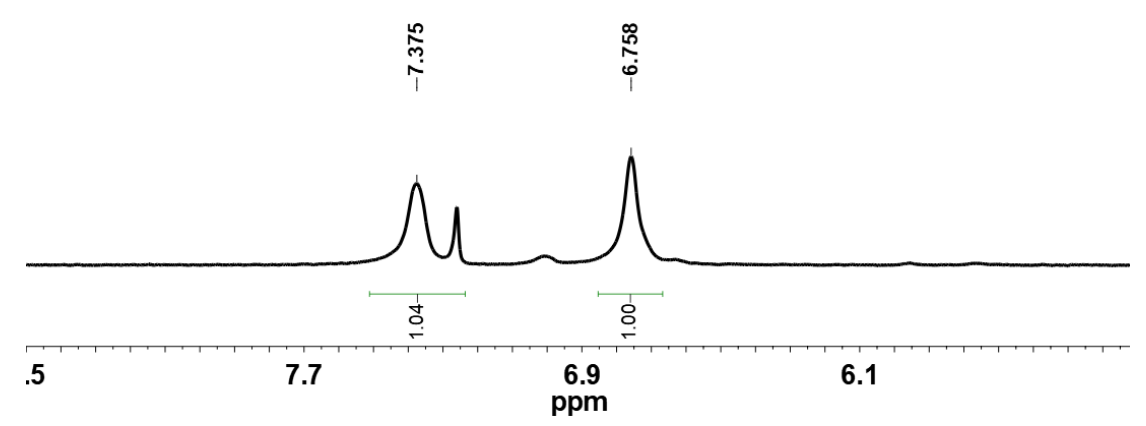

Figure S12. ${ }^{2} \mathrm{H}$ NMR spectrum of $(E, Z)-\mathrm{PhCH}=\mathrm{CH}-\mathrm{CD}=\mathrm{CDPh}$ in $\mathrm{CDCl}_{3}$.

\subsubsection{Semireduction of 5 a with $\mathrm{H}_{3} \mathrm{~N} \cdot \mathrm{BD}_{3}$ and $\mathrm{D}_{3} \mathrm{~N} \cdot \mathrm{BH}_{3}$}

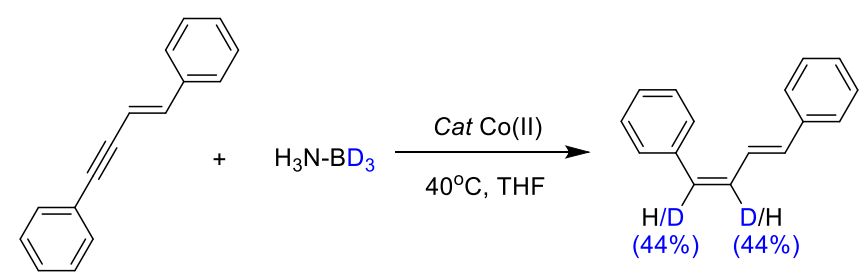

Complex $1(5.8 \mathrm{mg}, 0.012 \mathrm{mmol})$ was dissolved in $0.5 \mathrm{~mL}$ of THF in a $10 \mathrm{ml}$ vial inside a nitrogen-glove box. The 5a $(40.8 \mathrm{mg}, 0.2 \mathrm{mmol})$ and $\mathrm{H}_{3} \mathrm{~N} \cdot \mathrm{BD}_{3}(6.2 \mathrm{mg}, 0.2$ mmol) were added in the vial. The reaction was stirred at $40{ }^{\circ} \mathrm{C}$ for $4 \mathrm{~h}$. The residue was then purified by flash column chromatography on silica gel with petroleum ether. Yield: $28.7 \mathrm{mg}(70 \%) .{ }^{1} \mathrm{H}$ NMR $\left(500 \mathrm{MHz}, \mathrm{CDCl}_{3}\right) \delta$ 7.45-7.39 (m, 6H, ArH), 
7.38-7.28 (m, 3H, ArH, 1H, vinyl-H ), 7.28-7.23 (m, 1H, ArH), 6.74 (d, J=15.6 Hz, 1H), 6.56-6.53 (m, 1H, vinyl-H), 6.47-6.42 (m, 1H, vinyl-H).

究
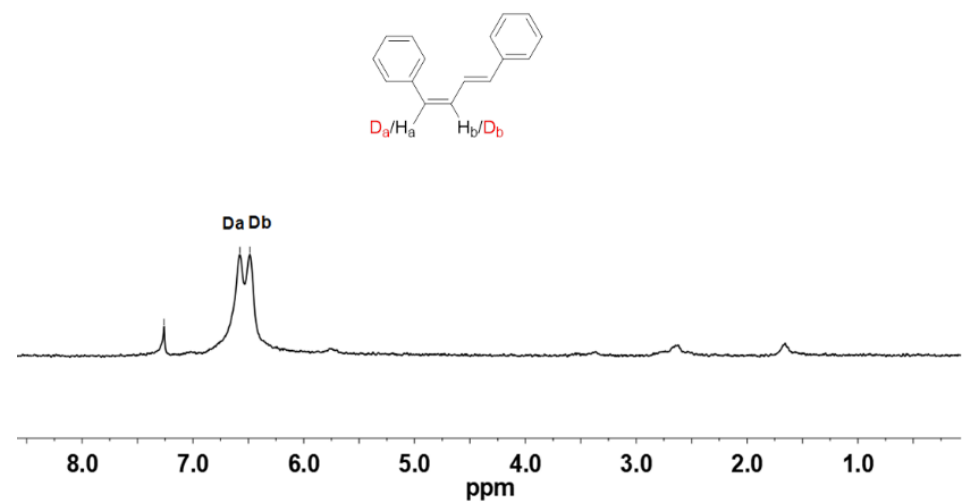

Figure S13. ${ }^{2} \mathrm{H}$ NMR spectrum of $d-\mathbf{3 a}$ in $\mathrm{CHCl}_{3}$.
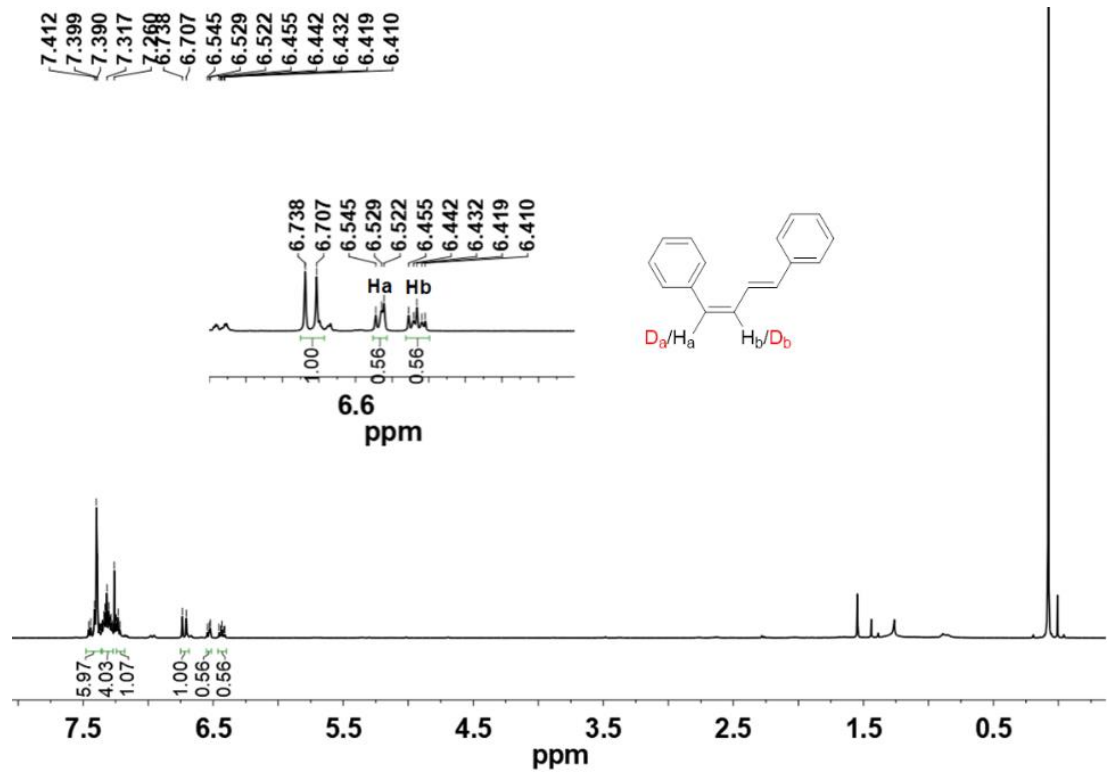

Figure S14. ${ }^{1} \mathrm{H}$ NMR spectrum of $d-\mathbf{3 a}$ in $\mathrm{CDCl}_{3}$.

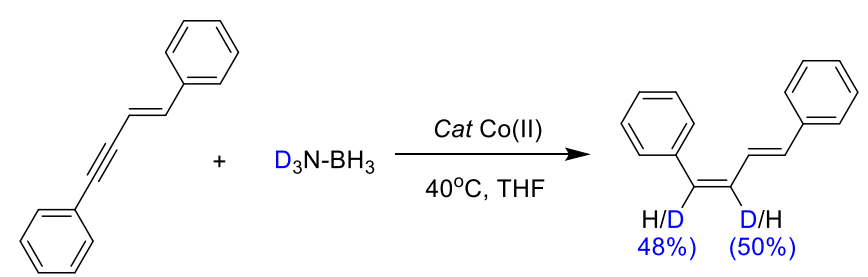

Complex $1(5.8 \mathrm{mg}, 0.012 \mathrm{mmol})$ was dissolved in $0.5 \mathrm{~mL}$ of THF in a $10 \mathrm{ml}$ vial inside a nitrogen-glove box. The 5a $(40.8 \mathrm{mg}, 0.2 \mathrm{mmol})$ and $\mathrm{D}_{3} \mathrm{~N} \cdot \mathrm{BH}_{3}(6.2 \mathrm{mg}$, $0.2 \mathrm{mmol}$ ) were added in the vial. The reaction was stirred at $40{ }^{\circ} \mathrm{C}$ for $4 \mathrm{~h}$. The 
residue was then purified by flash column chromatography on silica gel with petroleum ether. Yield: 24.6mg (60\%). ${ }^{1} \mathrm{H}$ NMR (500 MHz, $\left.\mathrm{CDCl}_{3}\right) \delta$ 7.45-7.39 (m, $6 \mathrm{H}, \mathrm{ArH}), 7.38-7.28$ (m, 3H, ArH, 1H, vinyl-H), 7.28-7.20 (m, 1H, ArH), 6.74 (d, J= 15.6 Hz, 1H, vinyl-H), 6.56-6.53 (m, 1H, vinyl-H), 6.47-6.42 (m, 1H, vinyl-H).

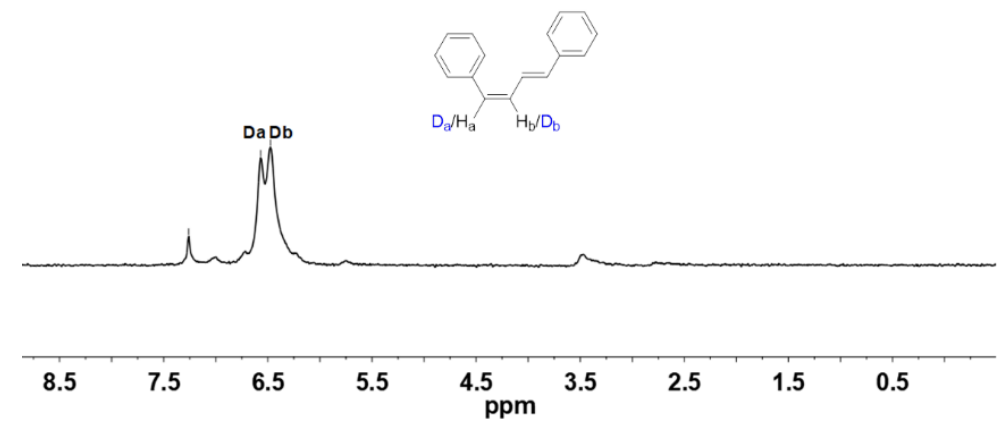

Figure S15. ${ }^{2} \mathrm{H}$ NMR spectrum of $d 2-\mathbf{3 a}$ in $\mathrm{CHCl}_{3}$.

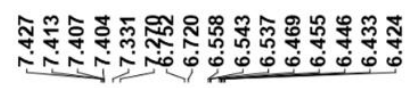

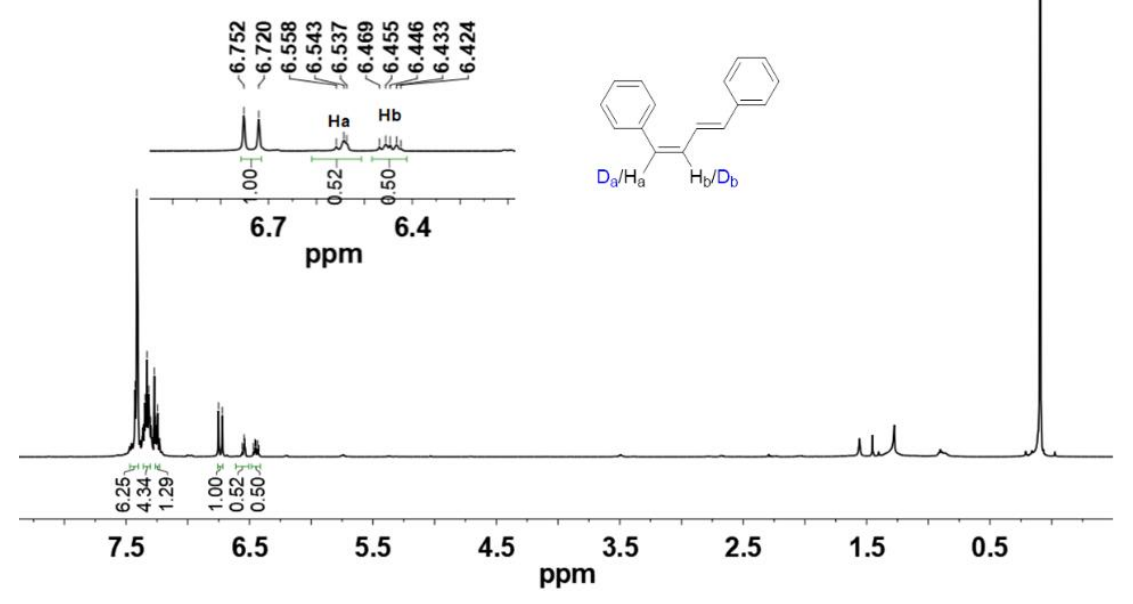

Figure S16. ${ }^{1} \mathrm{H}$ NMR spectrum of $d 2-3 \mathbf{a}$ in $\mathrm{CDCl}_{3}$. 


\section{DFT Results}

\subsection{Computational Details}

The density functional calculations were performed using the Gaussian 09 package. ${ }^{6}$ Geometries were optimized using the B3LYP-D3 ${ }^{7,8}$ functional with a combined basis set, in which Co was described by $\mathrm{SDD}^{9}$ pseudo potential and 6-31G(d,p) was used for all other elements. On the basis of the optimized geometries, frequencies were computed analytically at the same level of theory to identify the nature of all the stationary points and to obtain the Gibbs free energy corrections at $298.15 \mathrm{~K}$. The large basis and solvation energies in tetrahydrofuran $(\varepsilon=7.4257)$, were calculated as single points on the optimized structures using the $\mathrm{SMD}^{10}$ continuum solvation model with the B3LYP*-D3 ${ }^{11}$ functional (15\% Hartree-Fock exchange including D3 dispersion correction from B3LYP) employing a larger basis set, which is $6-311+\mathrm{G}(2 \mathrm{df}, 2 \mathrm{p})$ for all elements expect Co. It has been demonstrated that the use of $15 \% \mathrm{HF}$ exchange gave better relative energies of different spin states. ${ }^{12-14} \mathrm{~A}$ concentration correction of $1.9 \mathrm{kcal} / \mathrm{mol}$ at room temperature [derived from the free energy change of $1 \mathrm{~mol}$ of an ideal gas from $1 \mathrm{~atm}(24.5 \mathrm{~L} / \mathrm{mol})$ to $1 \mathrm{M}(1 \mathrm{~mol} / \mathrm{L})]$ was added for all species. ${ }^{15}$ The energy reported is B3LYP-D3* free energy including solvation corrections, Gibbs free energy corrections, and D3 dispersion corrections. 


\subsection{Relaxed potential energy surface scan for the side-on coordination of an} alkyne to Co.

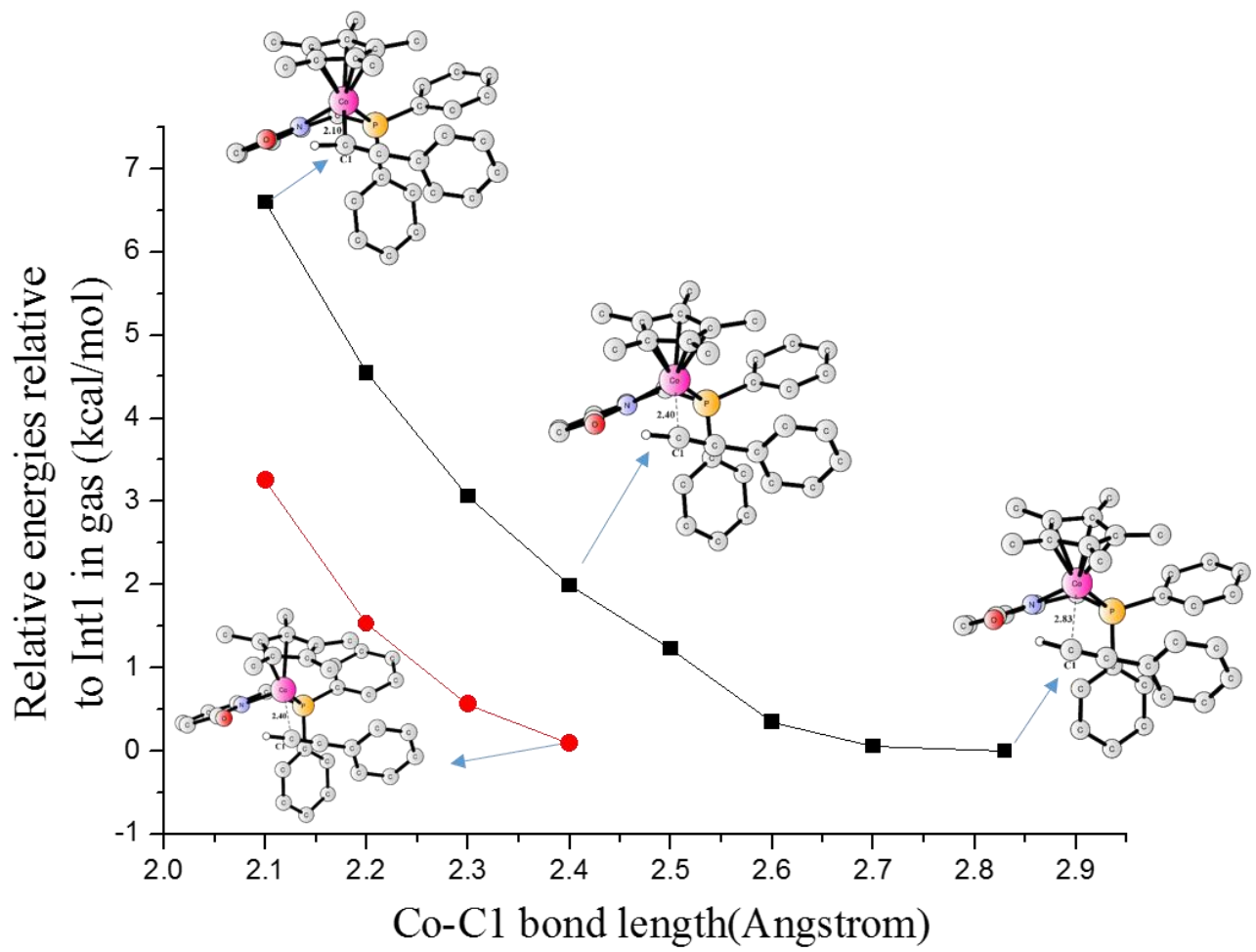

Figure S17. Relaxed potential energy surface scan for the side-on coordination of an alkyne to the Co center along the Co-C1 bond. Red and black dots represent different spins, red dot: quartet state, black dot: doublet state.

In Int1, the two Co-C distances are $2.48 \AA$ and $2.87 \AA$, respectively. A potential energy scan along the Co-C distance was performed (Fig. S17), and the energy increases with the decrease of the Co-C bond. 


\subsection{Isomerization of Int2 to Int3.}

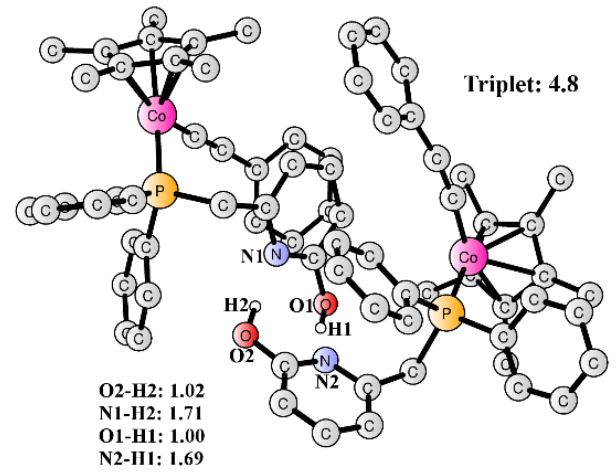

Dimer-Int2

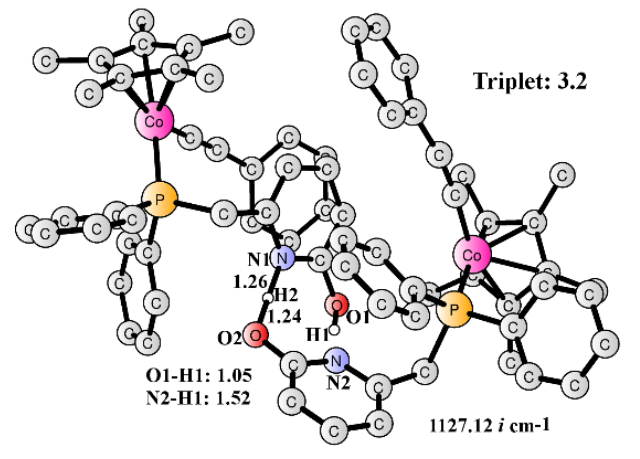

Dimer-Int2-TS

Figure S18. Optimized structures of Dimer-Int2 (triplet) and Dimer-Int2-TS (triplet). Distances are given in angstroms, relative energies are given in $\mathrm{kcal} / \mathrm{mol}$ relative to two equivalent Catalysts plus two equivalent phenylacetylenes. The imaginary frequencies are also indicated. 


\subsection{Other pathways from Int2 and Int4.}

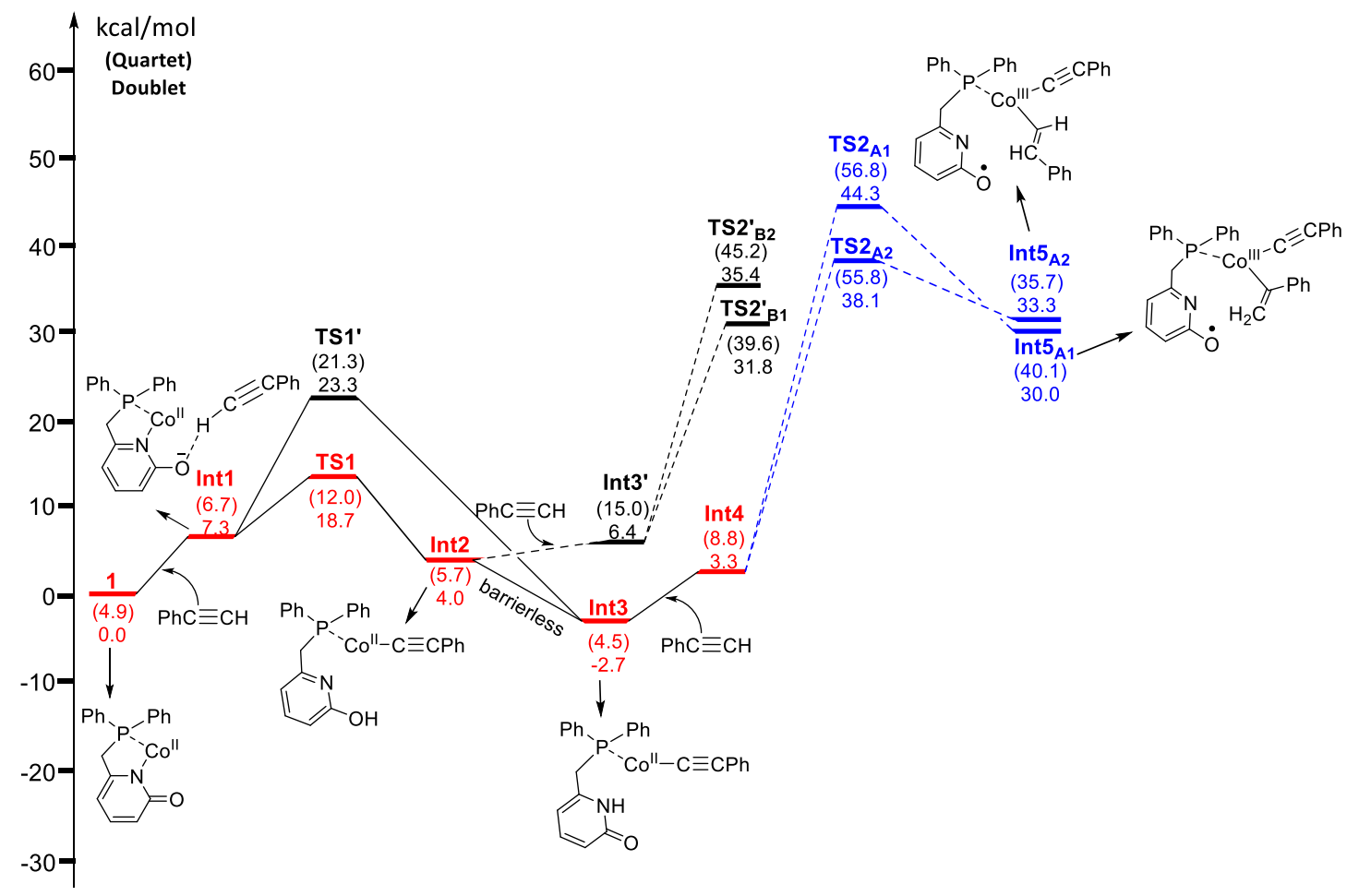

Figure S19. Gibbs energy diagram at the B3LYP*-D3/SDD-6-311+G(2df,2p)// B3LYP-D3/SDD-6-31G(d,p) level (in $\mathrm{kcal} / \mathrm{mol}$ ) for other pathways in the dimerization of phenylacetylene catalyzed by 1 . Energies in the quartet states are given in bracket. $\mathrm{Cp}^{*}$ is omitted for clarity.

For the alkynide migratory 1,2-insertion directly from Int3' to the terminal carbon of alkyne (TS2'B1) or to the internal $\alpha$-carbon of alkyne (TS2'B2), the barriers were calculated to be 31.8 and $35.4 \mathrm{kcal} / \mathrm{mol}$, respectively. These barriers are somewhat higher than that of $\mathbf{T S 2}_{\mathbf{B} 1}(27.1 \mathrm{kcal} / \mathrm{mol}$ relative to 1 plus two alkyne molecules) and less favorable. Another mechanistic scenario starting from Int4 has also considered, namely metalation of the second alkyne molecule in concomitant with a hydrogen atom transfer from the pyridonate nitrogen atom to the alkyne carbon. However, the barriers for the corresponding transition states TS2 $\mathbf{A 1}_{1}$ with hydrogen atom transfer to the internal $\alpha$-carbon of alkyne, and $\mathbf{T S 2} 2_{\mathbf{A} 2}$ with hydrogen atom transfer to the terminal carbon of alkyne were found to be about $40 \mathrm{kcal} / \mathrm{mol}$. The very high barrier also rules out this pathway as a viable option. 
9.5 Gibbs energy diagram for the dimerization of phenylacetylene catalyzed by 1 at the B3LYP*-D3 level.

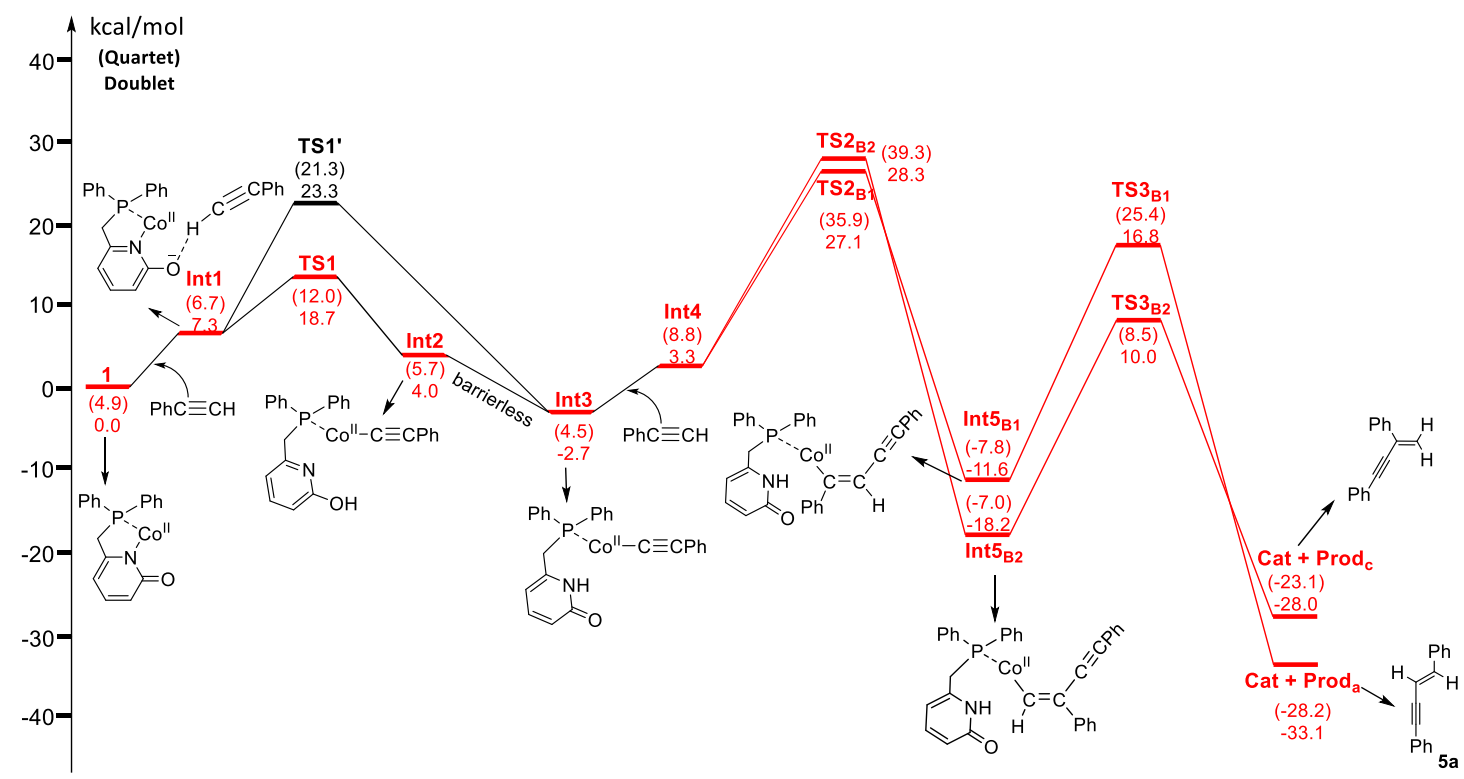

Figure S20. Gibbs energy diagram (in $\mathrm{kcal} / \mathrm{mol}$ ) for the dimerization of phenylacetylene catalyzed by 1 at the B3LYP*-D3 level. The most favorable pathway are shown here. Energies in the quratet states are given in bracket.

9.6 Gibbs energy diagram for Semireduction of 5a at the B3LYP*-D3 level.

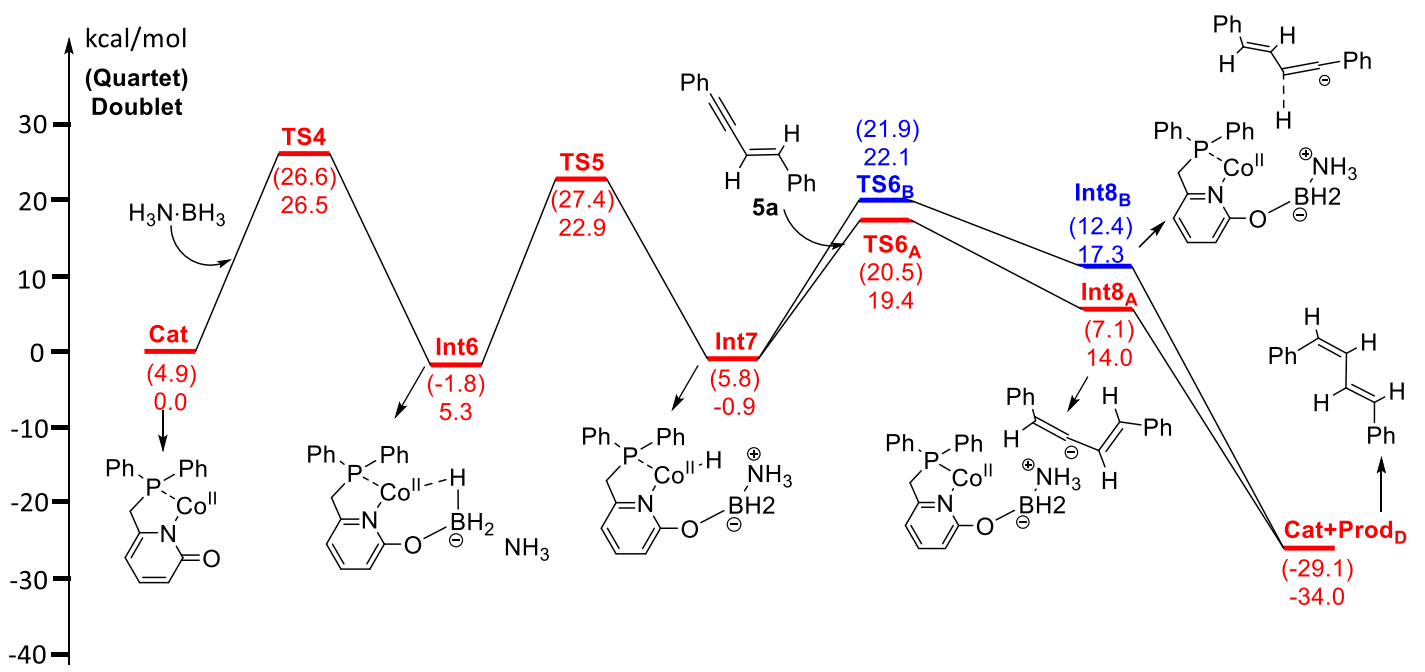

Figure S21. Gibbs energy diagram at the B3LYP*-D3 level for the semireduction of (E)-but-1-en-3-yne-1,4-diyldibenzene by $\mathrm{H}_{3} \mathrm{BNH}_{3}$ catalyzed by $\mathbf{1}$. Energies in the quratet states are given in bracket. 


\subsection{Optimized structures}

Table S1. Optimized structures

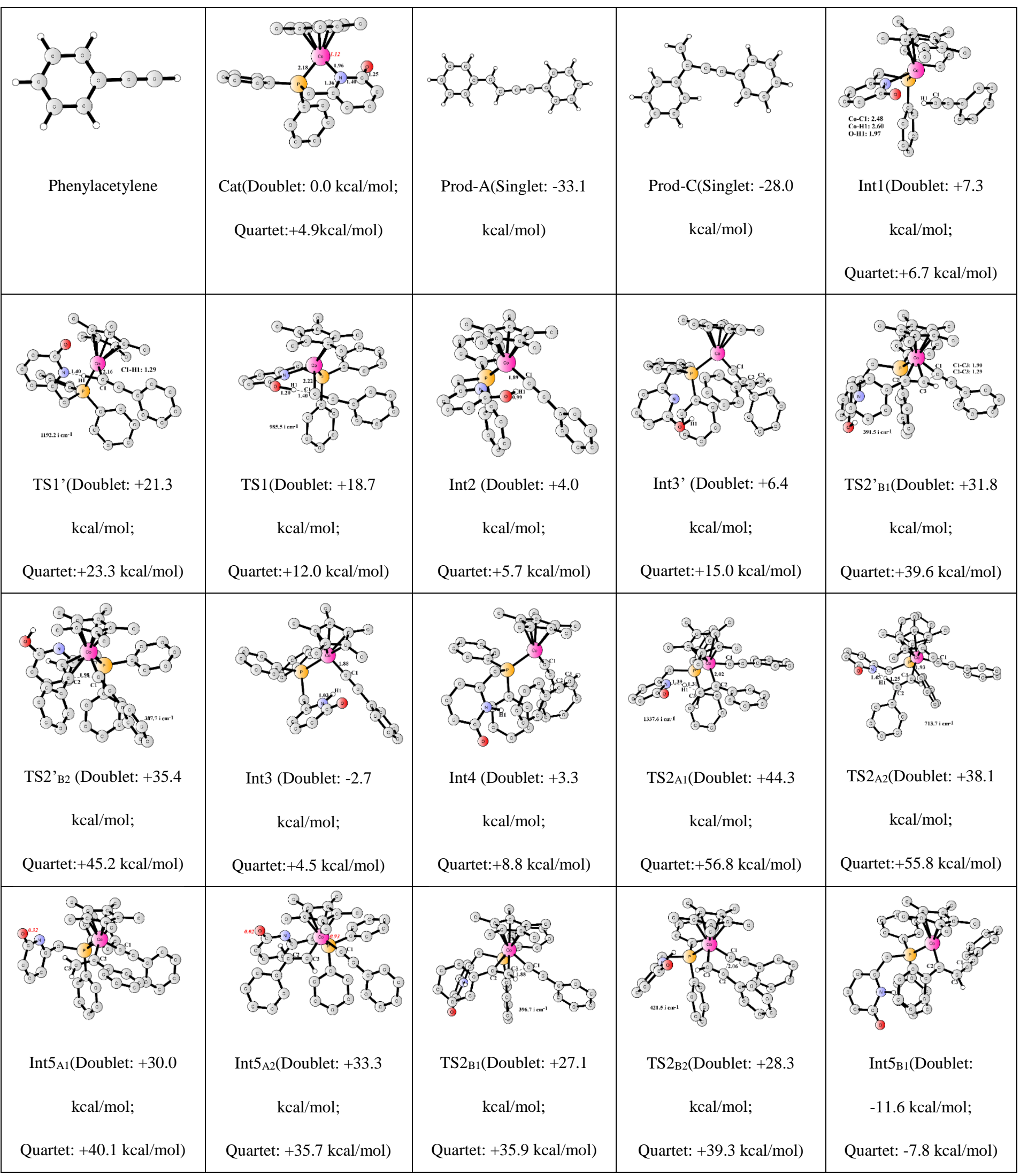




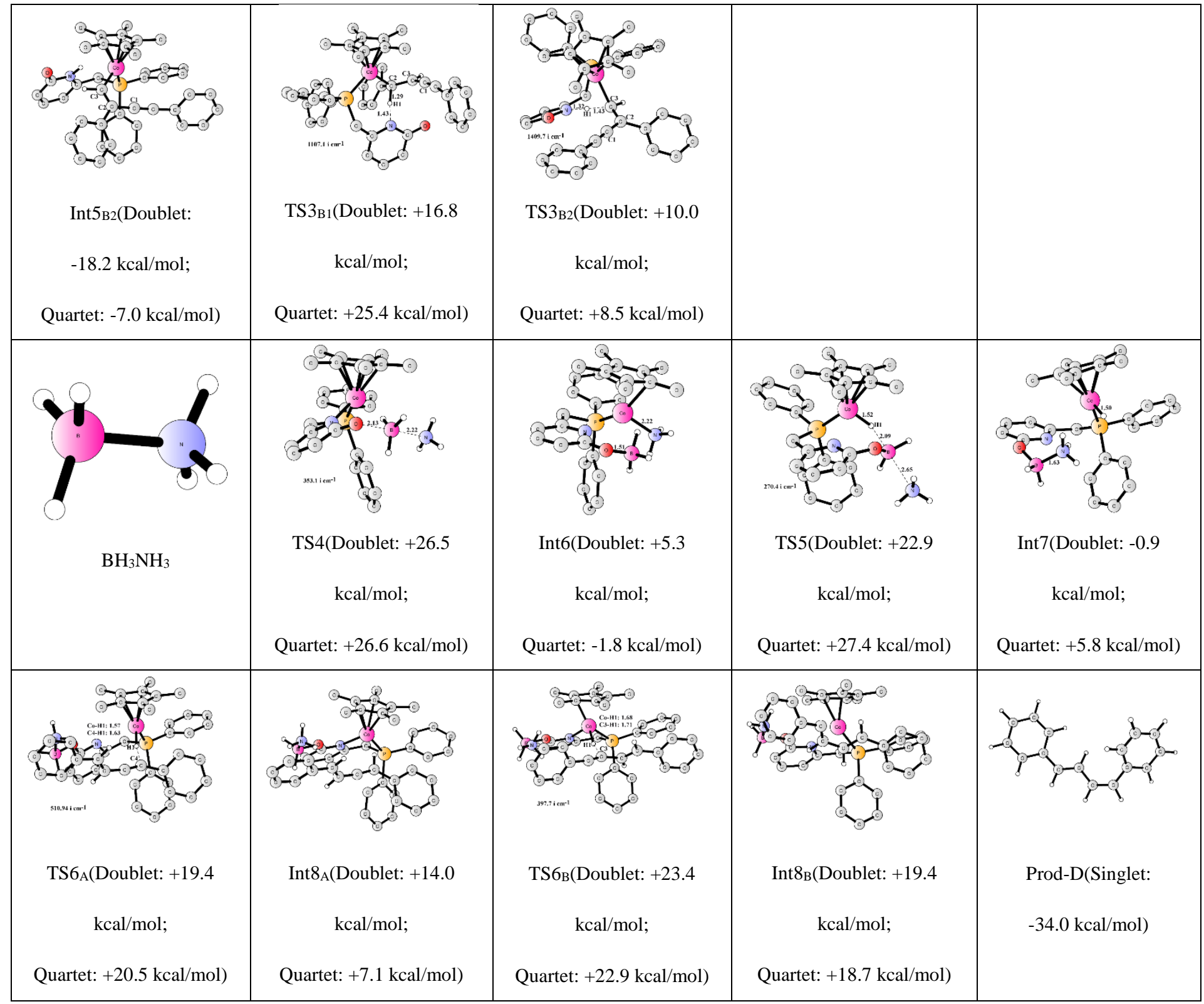




\subsection{Calculated energies in Hartree}

Table S2. Calculated energies in Hartree

\begin{tabular}{|c|c|c|c|c|c|}
\hline & $\begin{array}{c}\text { Geometry } \\
\text { optimization } \\
\text { energy (Hartree) }\end{array}$ & $\begin{array}{c}\text { Large basis } \\
\text { energy (Hartree) } \\
\text { [B3LYP*] }\end{array}$ & $\begin{array}{c}\text { Gibbs } \\
\text { energy } \\
\text { correction } \\
\text { (Hartree) }\end{array}$ & $\begin{array}{c}\text { Grimme-D3 } \\
\text { dispersion energy } \\
\text { correction } \\
\text { (Hartree) }\end{array}$ & $\begin{array}{c}\text { Large basis } \\
\text { energy (Hartree) } \\
\text { [M06] }\end{array}$ \\
\hline phenylacetylene & -308.40370 & -308.29521 & 0.0791 & -0.00709 & -308.25197 \\
\hline catalyst & -1702.39829 & -1701.81617 & 0.44459 & -0.08809 & -1701.80847 \\
\hline product-a & -616.88870 & -616.66025 & 0.18192 & -0.01778 & -616.57545 \\
\hline product-c & -616.88353 & -616.65101 & 0.18229 & -0.01933 & -616.56929 \\
\hline Int1 & -2010.83382 & -2010.08938 & 0.54653 & -0.12629 & -2010.07655 \\
\hline TS1 & -2010.82259 & -2010.07819 & 0.54371 & -0.12622 & -2010.06257 \\
\hline TS1' & -2010.79098 & -2010.06905 & 0.53808 & -0.11489 & -2010.03842 \\
\hline Int2 & -2010.82936 & -2010.10736 & 0.54792 & -0.11404 & -2010.07506 \\
\hline Int3 & -2010.83511 & -2010.11977 & 0.54943 & -0.11385 & -2010.08761 \\
\hline Int3' & -2318.34356 & -2318.38627 & 0.64210 & -0.14564 & -2318.34356 \\
\hline Int4 & -2319.24819 & -2318.39450 & 0.64684 & -0.14710 & -2318.34988 \\
\hline TS2'B1 & -2319.21266 & -2318.35001 & 0.64857 & -0.14799 & -2318.30827 \\
\hline TS2'B2 & -2319.20949 & -2318.34676 & 0.64945 & -0.14630 & -2318.30132 \\
\hline TS2A1 & -2319.18547 & -2318.32587 & 0.64737 & -0.15100 & -2318.27220 \\
\hline $\mathrm{TS} 2 \mathrm{~A} 2$ & -2319.19782 & -2318.33901 & 0.64875 & -0.14905 & -2318.28158 \\
\hline TS2B1 & -2319.21627 & -2318.35548 & 0.64943 & -0.15073 & -2318.31478 \\
\hline TS2B2 & -2319.21752 & -2318.35414 & 0.64850 & -0.14922 & -2318.30830 \\
\hline In5A1 & -2319.21498 & -2318.35649 & 0.65528 & -0.15097 & -2318.30347 \\
\hline In $5 \mathrm{~A} 2$ & -2319.21378 & -2318.34824 & 0.65365 & -0.15238 & -2318.29999 \\
\hline In5B 1 & -2319.28937 & -2318.41958 & 0.65612 & -0.15508 & -2318.38099 \\
\hline In5B2 & -2319.29881 & -2318.43301 & 0.65455 & -0.15054 & -2318.39317 \\
\hline TS3B1 & -2319.25923 & -2318.38208 & 0.64761 & -0.14952 & -2318.32168 \\
\hline TS3B2 & -2319.25281 & -2318.39610 & 0.64646 & -0.13682 & -2318.33799 \\
\hline
\end{tabular}




\begin{tabular}{cccccc}
\hline TS4 & -1785.61218 & -1784.97810 & 0.50776 & -0.10849 & -1784.98168 \\
Int6 & -1785.67017 & -1785.02010 & 0.51026 & -0.11404 & -1785.03108 \\
TS5 & -1785.61650 & -1784.98696 & 0.50507 & -0.10363 & -1784.98770 \\
Int7 & -1785.66410 & -1785.02668 & 0.51368 & -0.10959 & -1785.03261 \\
TS6A & -2402.55272 & -2401.64195 & 0.72102 & -0.16225 & -2401.59725 \\
TS6B & -2402.54777 & -2401.63456 & 0.71480 & -0.15789 & -2401.58927 \\
TS6H2 & -1785.63129 & -1784.99028 & 0.51108 & -0.11005 & -1784.98849 \\
Int8A & -2402.57578 & -2401.66944 & 0.72169 & -0.15590 & -2401.62385 \\
Int8B & -2402.57007 & -2401.64033 & 0.72750 & -0.15097 & -2401.61292 \\
BH3-NH3 & -83.22545 & -83.20987 & 0.04758 & -0.00182 & -83.20158 \\
product-d & -618.14303 & -617.90254 & 0.20721 & -0.02226 & -617.81695 \\
\hline
\end{tabular}




\section{Characterization data of $(E)$-enynes and 1,3-dibutadienes}

\subsection{Characterization data of $(E)$-enynes}

(E)-but-1-en-3-yne-1,4-diyldibenzene (5a) ${ }^{16}{ }^{1} \mathrm{H}$ NMR $\left(500 \mathrm{MHz}, \mathrm{CDCl}_{3}\right) \delta 7.37(\mathrm{dd}$, $J=7.6,1.9 \mathrm{~Hz}, 2 \mathrm{H}, \mathrm{ArH}), 7.29$ (d, $J=7.2 \mathrm{~Hz}, 2 \mathrm{H}, \mathrm{ArH}), 7.24-7.12(\mathrm{~m}, 6 \mathrm{H}, \mathrm{ArH})$, $6.93(\mathrm{~d}, J=16.2 \mathrm{~Hz}, 1 \mathrm{H}$, vinyl-H), 6.27 (d, $J=16.2 \mathrm{~Hz}, 1 \mathrm{H}$, vinyl-H).

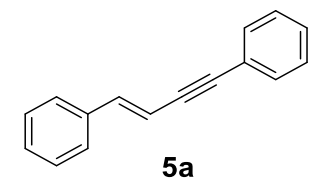

(E)-2,2'-(but-1-en-3-yne-1,4-diyl)bis(methylbenzene) (5b) ${ }^{17}{ }^{1} \mathrm{H}$ NMR (500 MHz, CDCl3) $\delta 7.43(\mathrm{dd}, J=7.7,4.9 \mathrm{~Hz}, 1 \mathrm{H}, \mathrm{ArH}), 7.38$ (d, $J=7.5 \mathrm{~Hz}, 1 \mathrm{H}, \mathrm{ArH}), 7.20$ (d, $J=16.1 \mathrm{~Hz}, 1 \mathrm{H}$, vinyl-H), 7.15-7.05 (m, 6H, ArH), 6.27 (d, $J=16.1 \mathrm{~Hz}, 1 \mathrm{H}$, vinyl-H), $2.41\left(\mathrm{~s}, 3 \mathrm{H}, \mathrm{CH}_{3}\right), 2.33\left(\mathrm{~s}, 3 \mathrm{H}, \mathrm{CH}_{3}\right)$.

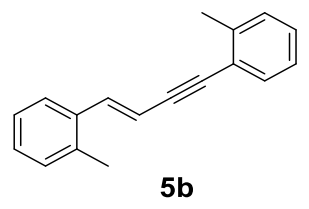

(E)-2,2'-(but-1-en-3-yne-1,4-diyl)bis(fluorobenzene) (5c) ${ }^{18}{ }^{1} \mathrm{H}$ NMR $(500 \mathrm{MHz}$, $\left.\mathrm{CDCl}_{3}\right) \delta$ 7.60-7.53 (m, 2H, ArH), 7.45-7.31 (m, 2H, ArH), 7.28 (d, J=16.4 Hz, 1H, vinyl-H), 7.21-7.11 (m, 4H, ArH), 6.58 (d, $J=16.4 \mathrm{~Hz}, 1 \mathrm{H}$, vinyl-H).

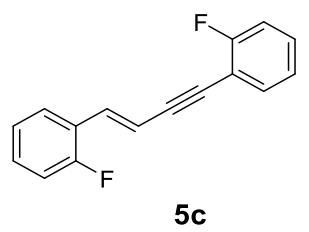

(E)-3,3'-(but-1-en-3-yne-1,4-diyl)bis(methylbenzene) (5d) ${ }^{18}{ }^{1} \mathrm{H}$ NMR (500 MHz, $\left.\mathrm{CDCl}_{3}\right) \delta$ 7.38-7.31 (m, 2H, ArH), 7.30-7.23 (m, 4H, ArH), $7.15(\mathrm{dd}, J=8.7,5.7 \mathrm{~Hz}$, 2H, ArH), 7.04 (d, $J=16.2 \mathrm{~Hz}, 1 \mathrm{H}$, vinyl-H), 6.41 (d, $J=16.2 \mathrm{~Hz}, 1 \mathrm{H}$, vinyl-H), 2.38 $\left(\mathrm{d}, J=8.7 \mathrm{~Hz}, 6 \mathrm{H}, \mathrm{CH}_{3}\right)$.

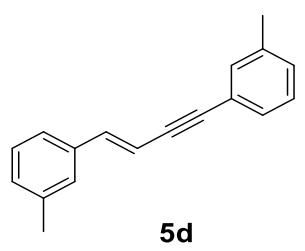


(E)-3,3'-(but-1-en-3-yne-1,4-diyl)bis(fluorobenzene) $\quad(\mathbf{5 e})^{18} \quad{ }^{1} \mathrm{H} \quad \mathrm{NMR} \quad(500 \mathrm{MHz}$, $\left.\mathrm{CDCl}_{3}\right) \delta$ 7.24-7.14 (m, 3H, ArH), 7.10-7.02 (m, 3H, ArH), 6.96-6.88 (m, 2H, ArH, $1 \mathrm{H}$, vinyl-H), 6.37 (d, $J=16.2 \mathrm{~Hz}, 1 \mathrm{H}$, vinyl-H).

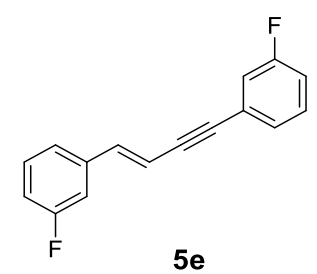

(E)-3,3'-(but-1-en-3-yne-1,4-diyl)bis(chlorobenzene) $\quad(\mathbf{5 f})^{17}{ }^{1} \mathrm{H} \quad \mathrm{NMR} \quad(500 \mathrm{MHz}$, $\left.\mathrm{CDCl}_{3}\right) \delta 7.38(\mathrm{~s}, 1 \mathrm{H}, \mathrm{ArH}), 7.33(\mathrm{~s}, 1 \mathrm{H}, \mathrm{ArH}), 7.24-7.22$ (m, 1H, ArH), 7.24-7.16 (m, 5H, ArH), 6.90 (d, $J=16.2 \mathrm{~Hz}, 1 \mathrm{H}$, vinyl-H), 6.29 (d, $J=16.2 \mathrm{~Hz}, 1 \mathrm{H}$, vinyl-H).

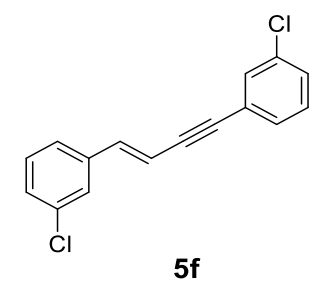

(E)-4,4'-(but-1-en-3-yne-1,4-diyl)bis(methylbenzene) $\quad(\mathbf{5 g})^{18} \quad{ }^{1} \mathrm{H} \quad \mathrm{NMR}(500 \mathrm{MHz}$, $\left.\mathrm{CDCl}_{3}\right) \delta 7.41(\mathrm{~d}, J=8.0 \mathrm{~Hz}, 2 \mathrm{H}, \mathrm{ArH}), 7.35(\mathrm{~d}, J=8.0 \mathrm{~Hz}, 2 \mathrm{H}, \mathrm{ArH}), 7.23-7.12(\mathrm{~m}$, 4H, ArH), 7.04 (d, $J=16.2 \mathrm{~Hz}, 1 \mathrm{H}$, vinyl-H), 6.37 (d, $J=16.2 \mathrm{~Hz}, 1 \mathrm{H}$, vinyl-H), 2.39 (s, 6H, $\left.\mathrm{CH}_{3}\right)$.

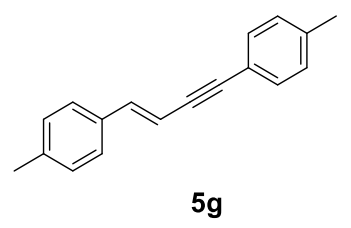

(E)-4,4'-(but-1-en-3-yne-1,4-diyl)bis(fluorobenzene) $(\mathbf{5 h})^{18}{ }^{1} \mathrm{H} \quad \mathrm{NMR} \quad(500 \mathrm{MHz}$, $\left.\mathrm{CDCl}_{3}\right) \delta 7.45(\mathrm{dd}, J=8.6,5.4 \mathrm{~Hz}, 2 \mathrm{H}, \mathrm{ArH}), 7.39(\mathrm{dd}, J=8.6,5.4 \mathrm{~Hz}, 2 \mathrm{H}, \mathrm{ArH})$, 7.06-7.01 (m, 4H, ArH), 6.99 (d, $J=16.3 \mathrm{~Hz}, 1 \mathrm{H}$, vinyl-H), $6.28(\mathrm{~d}, J=16.2 \mathrm{~Hz}, 1 \mathrm{H}$, vinyl-H).

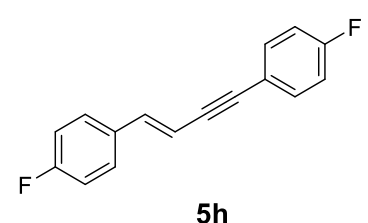


(E)-4,4'-(but-1-en-3-yne-1,4-diyl)bis(methoxybenzene) $(5 \mathbf{5 i})^{18} \quad{ }^{1} \mathrm{H}$ NMR $(500 \mathrm{MHz}$, $\left.\mathrm{CDCl}_{3}\right) \delta 7.41(\mathrm{~d}, J=8.8 \mathrm{~Hz}, 2 \mathrm{H}, \mathrm{ArH}), 7.36(\mathrm{~d}, J=8.7 \mathrm{~Hz}, 2 \mathrm{H}, \mathrm{ArH}), 6.96(\mathrm{~d}, J=$ 16.2 Hz, 1H, vinyl-H), 6.89-6.76 (m, 4H, ArH), 6.24 (d, $J=16.2 \mathrm{~Hz}, 1 \mathrm{H}$, vinyl-H), $3.82\left(\mathrm{~s}, 6 \mathrm{H}, \mathrm{OCH}_{3}\right)$.

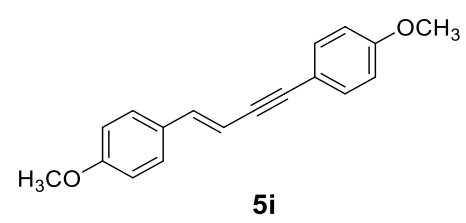

(E)-4,4'-(but-1-en-3-yne-1,4-diyl)bis((trifluoromethyl)benzene) $(5 \mathbf{j}){ }^{18}{ }^{1} \mathrm{H}$ NMR (500 $\left.\mathrm{MHz}, \mathrm{CDCl}_{3}\right) \delta$ 7.47-7.42 (m, 2H, ArH), 7.41-7.36 (m, 2H, $\left.\mathrm{ArH}\right), 7.06-7.01$ (m, 4H, ArH), 6.99 (d, $J=16.2 \mathrm{~Hz}, 1 \mathrm{H}$, vinyl-H), 6.28 (d, $J=16.2 \mathrm{~Hz}, 1 \mathrm{H}$, vinyl-H).

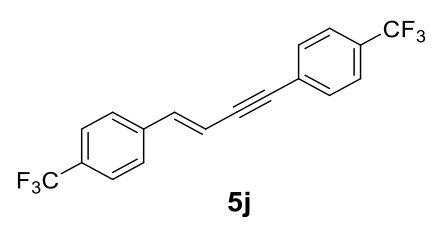

(E)-4,4'-(but-1-en-3-yne-1,4-diyl)bis(tert-butylbenzene) (5k $)^{16}{ }^{1} \mathrm{H}$ NMR $(500 \mathrm{MHz}$, $\left.\mathrm{CDCl}_{3}\right) \delta$ 7.44-7.31 (m, 8H, ArH), $7.01(\mathrm{~d}, J=16.2 \mathrm{~Hz}, 1 \mathrm{H}$, vinyl-H), $6.34(\mathrm{~d}, J=$ $16.2 \mathrm{~Hz}, 1 \mathrm{H}$, vinyl-H), 1.32 (s, 9H, $\left.\mathrm{CH}_{3}\right), 1.31$ (s, 9H, $\left.\mathrm{CH}_{3}\right)$.

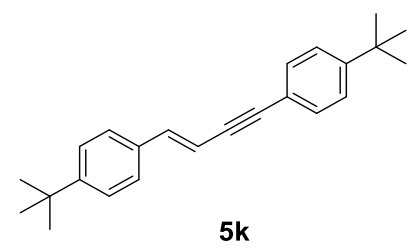

(E)-5,5'-(but-1-en-3-yne-1,4-diyl)bis(1,3-bis(trifluoromethyl)benzene) (5l) ${ }^{19}{ }^{1} \mathrm{H}$ NMR $\left(500 \mathrm{MHz}, \mathrm{CDCl}_{3}\right) \delta$ 8.14-7.60 (m, 6H, ArH), $7.18(\mathrm{~d}, J=16.2,1 \mathrm{H}$, vinyl-H), 6.55 (d, $J=16.1,1 \mathrm{H}$, vinyl-H). MS (EI): m/z calcd. for $\mathrm{C}_{20} \mathrm{H}_{8} \mathrm{~F}_{12}: 476.04$ GC-MS: m/z 476.15.

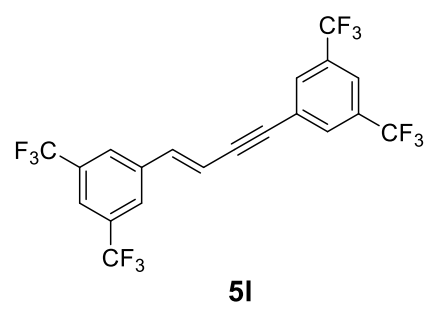

(E)-2,2'-(but-1-en-3-yne-1,4-diyl)dinaphthalene (5m) ${ }^{20}{ }^{1} \mathrm{H} \mathrm{NMR}\left(500 \mathrm{MHz}, \mathrm{CDCl}_{3}\right) \delta$ $8.02(\mathrm{~s}, 1 \mathrm{H}, \mathrm{ArH}), 7.89-7.77$ (m, 7H, ArH), 7.66-7.64 (m, 1H, ArH), 7.55 (d, $J=8.4$ 
$\mathrm{Hz}, 1 \mathrm{H}, \mathrm{ArH}), 7.52-7.41$ (m, 4H, ArH), 7.27 (d, $J=16.2 \mathrm{~Hz}, 1 \mathrm{H}$, vinyl-H), 6.56 (d, $J=$ $16.2 \mathrm{~Hz}, 1 \mathrm{H}$, vinyl-H).

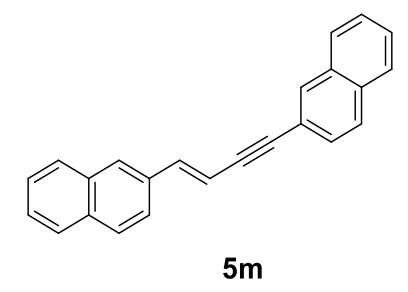

(E)-3,3'-(but-1-en-3-yne-1,4-diyl)dithiophene (5n) ${ }^{17}{ }^{1} \mathrm{H}$ NMR $\left(500 \mathrm{MHz}, \mathrm{CDCl}_{3}\right) \delta$ 7.44 (d, $J=2.7 \mathrm{~Hz}, 1 \mathrm{H}, \operatorname{ArH}), 7.33-7.20$ (m, 4H, ArH), 7.13 (d, $J=5.0 \mathrm{~Hz}, 1 \mathrm{H}, \operatorname{ArH})$, 7.01 (d, $J=16.1 \mathrm{~Hz}, 1 \mathrm{H}$, vinyl-H), 6.18 (d, $J=16.1 \mathrm{~Hz}, 1 \mathrm{H}$, vinyl-H).

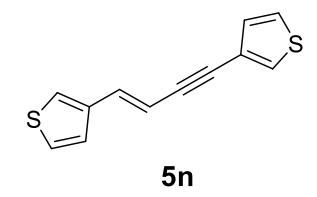

(E)-but-1-en-3-yne-1,4-diylbis(trimethylsilane) $\quad((E)-50)^{16} \quad{ }^{1} \mathrm{H} \quad \mathrm{NMR} \quad(500 \mathrm{MHz}$, $\left.\mathrm{CDCl}_{3}\right) \delta 6.52(\mathrm{~d}, J=19.3 \mathrm{~Hz}, 1 \mathrm{H}$, vinyl-H), $5.98(\mathrm{~d}, J=19.3 \mathrm{~Hz}, 1 \mathrm{H}$, vinyl-H), 0.20 (s, 9H, $\left.\mathrm{CH}_{3}\right), 0.09$ (s, 9H, $\left.\mathrm{CH}_{3}\right)$.

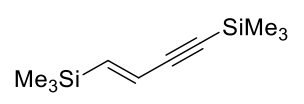

$(E)-50$

(Z)-but-1-en-3-yne-1,4-diylbis(trimethylsilane) $\quad((Z)-50){ }^{16} \quad{ }^{1} \mathrm{H} \quad \mathrm{NMR} \quad(500 \mathrm{MHz}$, $\left.\mathrm{CDCl}_{3}\right) \delta 6.27(\mathrm{~d}, J=15.1 \mathrm{~Hz}, 1 \mathrm{H}$, vinyl-H), $6.17(\mathrm{~d}, J=15.1 \mathrm{~Hz}, 1 \mathrm{H}$, vinyl-H), 0.20 (s, 9H, $\left.\mathrm{CH}_{3}\right), 0.08\left(\mathrm{~s}, 9 \mathrm{H}, \mathrm{CH}_{3}\right)$.

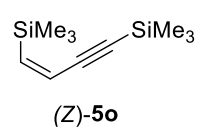

(E)-trimethyl(4-(naphthalen-2-yl)but-1-en-3-yn-1-yl)silane (5p) ${ }^{1} \mathrm{H}$ NMR $(500 \mathrm{MHz}$, $\left.\mathrm{CDCl}_{3}\right) \delta$ 7.88-7.74 (m, 4H, ArH), 7.56-7.54 (m, 1H, ArH), 7.51-7.42 (m, 2H, ArH), 7.17 (d, $J=16.3 \mathrm{~Hz}, 1 \mathrm{H}$, vinyl-H), 6.30 (d, $J=16.3 \mathrm{~Hz}, 1 \mathrm{H}$, vinyl-H), 0.25 (s, 9H, $\left.\mathrm{CH}_{3}\right) .{ }^{13} \mathrm{C} \mathrm{NMR}\left(126 \mathrm{MHz}, \mathrm{CDCl}_{3}\right) \delta 142.46,133.69,128.47,128.28,127.73,127.00$, 126.52, 124.45, 122.77, 108.37, 104.58, 97.30, 0.00. MS (EI): m/z calcd. for $\mathrm{C}_{17} \mathrm{H}_{18} \mathrm{Si}: 250.12$ GC-MS: m/z 250.10.

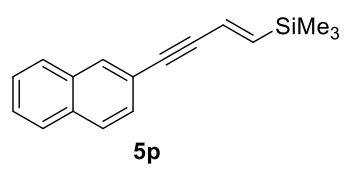




\subsection{Characterization data of 1,3-dibutadienes}

(1Z,3E)-1,4-diphenylbuta-1,3-diene (3a) ${ }^{21}{ }^{1} \mathrm{H}$ NMR $\left(500 \mathrm{MHz}, \mathrm{CDCl}_{3}\right) \delta$ 7.44-7.36 (m, 5H, ArH, 1H, vinyl-H), 7.36-7.27 (m, 4H, ArH), 7.23 (t, $J=7.3 \mathrm{~Hz}, 1 \mathrm{H}, \operatorname{ArH})$, $6.73(\mathrm{~d}, J=15.5 \mathrm{~Hz}, 1 \mathrm{H}$, vinyl-H), 6.54 (d, $J=11.4 \mathrm{~Hz}, 1 \mathrm{H}$, vinyl-H), 6.44 (t, $J=$ $11.3 \mathrm{~Hz}, 1 \mathrm{H}$, vinyl-H). ${ }^{13} \mathrm{C}$ NMR $\left(126 \mathrm{MHz} \mathrm{CDCl}_{3}\right) \delta 136.64,136.30,133.83,129.37$, 129.30, 128.04, 127.60, 127.34, 126.67, 126.02, 125.56, 124.21. MS (EI): m/z calcd. for $\mathrm{C}_{16} \mathrm{H}_{12}: 206.11$ GC-MS: m/z 206.00.

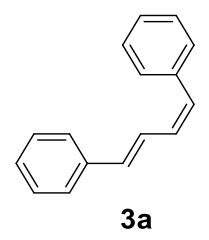

(1Z,3E)-1,4-di-o-tolylbuta-1,3-diene (3b) ${ }^{21}{ }^{1} \mathrm{H}$ NMR (500 MHz, CDCl3) $\delta$ 7.35-7.30 (m, 1H, ArH), 7.30-7.23 (m, 1H, ArH), 7.17-7.11 (m, 3H, ArH), 7.09-7.01 (m, 3H, ArH), 6.95 (dd, $J=15.5,10.5 \mathrm{~Hz}, 1 \mathrm{H}$, vinyl-H), 6.84 (d, $J=15.5 \mathrm{~Hz}, 1 \mathrm{H}$, vinyl-H), $6.50\left(\mathrm{~d}, J=11.3 \mathrm{~Hz}, 1 \mathrm{H}\right.$, vinyl-H), 6.47-6.40 (m, 1H, vinyl-H), 2.31 (s, 3H, $\left.\mathrm{CH}_{3}\right)$, $2.24\left(\mathrm{~s}, 3 \mathrm{H}, \mathrm{CH}_{3}\right) .{ }^{13} \mathrm{C} \mathrm{NMR}\left(126 \mathrm{MHz}, \mathrm{CDCl}_{3}\right) \delta 135.60,135.44,135.19,134.59$, $130.83,129.73,129.38,129.00,128.69,128.61,126.48,126.28,125.61,125.04$, 124.51, 124.36, 18.97, 18.81. MS (EI): m/z calcd. for $\mathrm{C}_{18} \mathrm{H}_{18}: 234.14$ GC-MS: m/z 234.10 .

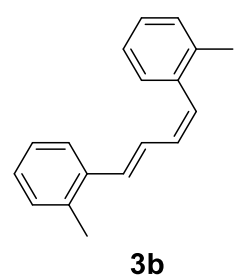

(1Z,3E)-1,4-bis(2-fluorophenyl)buta-1,3-diene (3c) ${ }^{1} \mathrm{H}$ NMR (500 MHz, $\left.\mathrm{CDCl}_{3}\right) \delta$ 7.46-7.43 (m, 2H, ArH), 7.32-7.25 (m, 2H, ArH), 7.24-7.13 (m, 3H, ArH), 7.12-7.01 (m, 3H, ArH, 1H, vinyl-H), 6.89 (d, $J=15.8 \mathrm{~Hz}, 1 \mathrm{H}$, vinyl-H), 6.63-6.48 (m, 2H, vinyl-H). ${ }^{13} \mathrm{C}$ NMR $\left(126 \mathrm{MHz}, \mathrm{CDCl}_{3}\right) \delta 159.35(\mathrm{~d}, J=250.9 \mathrm{~Hz}), 159.19(\mathrm{~d}, J=$ $248.7 \mathrm{~Hz}), 131.0,129.90(\mathrm{~d}, J=3.3 \mathrm{~Hz}), 128.03$ (d, $J=1.2 \mathrm{~Hz}), 127.96$ (d, $J=0.9$ $\mathrm{Hz}), 126.50$ (d, $J=3.3 \mathrm{~Hz}), 126.31,126.27$ (d, $J=3.3 \mathrm{~Hz}), 124.11,123.11$ (d, $J=3.6$ Hz), 122.77 (d, $J=3.6 \mathrm{~Hz}), 122.53(\mathrm{~d}, J=3.5 \mathrm{~Hz}), 114.82$ (d, $J=22.2 \mathrm{~Hz}), 114.75$ (d, 
$J=22.2 \mathrm{~Hz}), 114.58(\mathrm{~d}, J=22.2 \mathrm{~Hz}) . \mathrm{MS}(\mathrm{EI}): \mathrm{m} / \mathrm{z}$ calcd. for $\mathrm{C}_{16} \mathrm{H}_{12} \mathrm{~F}_{2}: 242.09$ GC-MS: $\mathrm{m} / \mathrm{z} 242.05$.

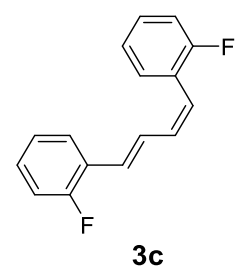

(1Z,3E)-1,4-di-m-tolylbuta-1,3-diene (3d) ${ }^{1} \mathrm{H}$ NMR (500 MHz, $\left.\mathrm{CDCl}_{3}\right) \delta$ 7.41-7.26 (m, 4H, ArH, 1H, vinyl-H), 7.22-7.15 (m, 2H, ArH), 7.12-7.04 (m, 2H, ArH), 6.74 (d, $J=15.5 \mathrm{~Hz}, 1 \mathrm{H}$, vinyl-H), $6.55(\mathrm{~d}, J=11.5 \mathrm{~Hz}, 1 \mathrm{H}$, vinyl-H), 6.46 (t, $J=11.3 \mathrm{~Hz}, 1 \mathrm{H}$, vinyl-H), 2.45 (s, 3H, CH3), 2.40 (s, 3H,CH3). ${ }^{13} \mathrm{C}$ NMR (126 MHz, $\left.\mathrm{CDCl}_{3}\right) \delta 137.15$, $136.93,136.65,136.31,133.80,129.31,129.28,128.78,127.50,127.48,127.24$, 126.78, 126.31, 125.13, 124.20, 122.69, 20.42, 20.37. MS (EI): $\mathrm{m} / \mathrm{z}$ calcd. for $\mathrm{C}_{18} \mathrm{H}_{18}$ : 234.14 GC-MS: m/z 234.10.

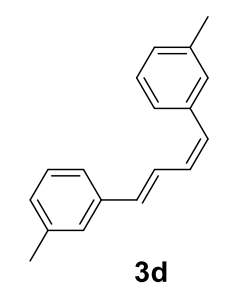

(1Z,3E)-1,4-bis(3-fluorophenyl)buta-1,3-diene (3e) ${ }^{1} \mathrm{H}$ NMR $\left(500 \mathrm{MHz}, \mathrm{CDCl}_{3}\right) \delta$ 7.38-7.33 (m, 1H, ArH), 7.31-7.27 (m, 1H, ArH), $7.24(\mathrm{~d}, J=11.1 \mathrm{~Hz}, 1 \mathrm{H}, \mathrm{ArH})$, $7.16(\mathrm{~m}, 1 \mathrm{H}, \mathrm{ArH}, 1 \mathrm{H}$, vinyl-H), 7.11-7.05 (m, 2H, ArH), $7.00(\mathrm{td}, J=8.4,2.4 \mathrm{~Hz}, 1 \mathrm{H}$, ArH), 6.96-6.91 (m, 1H, ArH), 6.69 (d, $J=15.5 \mathrm{~Hz}, 1 \mathrm{H}$, vinyl-H), 6.51 (d, $J=11.5$ $\mathrm{Hz}, 1 \mathrm{H}$, vinyl-H), 6.44 (t, $J=11.2 \mathrm{~Hz}, 1 \mathrm{H}$, vinyl-H). ${ }^{13} \mathrm{C} \mathrm{NMR}\left(126 \mathrm{MHz}, \mathrm{CDCl}_{3}\right) \delta$ $162.10(\mathrm{~d}, J=245.83 \mathrm{~Hz}), 161.81(\mathrm{~d}, J=246.46 \mathrm{~Hz}), 138.55(\mathrm{~d}, J=7.7 \mathrm{~Hz}), 138.40$ (d, $J=7.7 \mathrm{~Hz}), 133.34$ (d, $J=2.8 \mathrm{~Hz}), 129.83,129.07$ (d, $J=8.4 \mathrm{~Hz}), 128.89,128.85$ (d, $J=6.4 \mathrm{~Hz}), 124.85,123.76$ (d, $J=2.8 \mathrm{~Hz}), 121.52(\mathrm{~d}, J=2.7 \mathrm{~Hz}), 114.67(\mathrm{~d}, J=$ $21.5 \mathrm{~Hz}), 113.66(\mathrm{~d}, J=21.5 \mathrm{~Hz}), 113.09(\mathrm{~d}, J=21.3 \mathrm{~Hz}), 111.93(\mathrm{~d}, J=21.8 \mathrm{~Hz})$. MS (EI): m/z calcd. for $\mathrm{C}_{16} \mathrm{H}_{12} \mathrm{~F}_{2}$ : 242.09 GC-MS: m/z 242.10. 


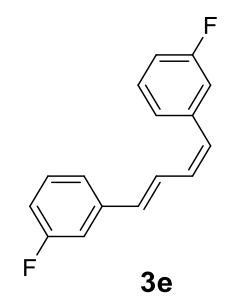

(1Z,3E)-1,4-bis(3-chlorophenyl)buta-1,3-diene (3f) ${ }^{1} \mathrm{H}$ NMR (500 MHz, $\left.\mathrm{CDCl}_{3}\right) \delta$ 7.28-7.23 (m, 3H, ArH), 7.21-7.17 (m, 3H, ArH, 1H, vinyl-H), 7.16-7.11 (m, 2H, ArH), $6.58(\mathrm{~d}, J=15.5 \mathrm{~Hz}, 1 \mathrm{H}$, vinyl-H), $6.41(\mathrm{~d}, J=11.5 \mathrm{~Hz}, 1 \mathrm{H}$, vinyl-H), $6.36(\mathrm{t}, J$ $=11.1 \mathrm{~Hz}, 1 \mathrm{H}$, vinyl- $\mathrm{H}) .{ }^{13} \mathrm{C}$ NMR $(126 \mathrm{MHz}, \mathrm{CDCl} 3) \delta 138.15,137.91,133.63$, $133.35,133.18,130.00,128.85,128.74,128.65,127.94,126.78,126.25,126.10$, 125.54, 124.82, 123.72. MS (EI): m/z calcd. for $\mathrm{C}_{16} \mathrm{H}_{12} \mathrm{Cl}_{2}: 274.03$ GC-MS: $\mathrm{m} / \mathrm{z}$ 274.00 .

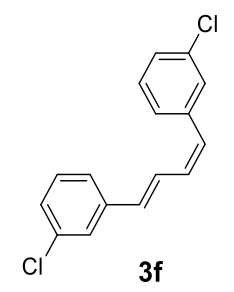

(1Z,3E)-1,4-di-p-tolylbuta-1,3-diene (3g) ${ }^{1} \mathrm{H}$ NMR (500 MHz, $\left.\mathrm{CDCl}_{3}\right) \delta$ 7.26-7.18 (m, $3 \mathrm{H}, \mathrm{ArH}, 1 \mathrm{H}$, vinyl-H), 7.11 (d, $J=7.9 \mathrm{~Hz}, 2 \mathrm{H}, \mathrm{ArH}), 7.04(\mathrm{~d}, J=8.0 \mathrm{~Hz}, 2 \mathrm{H}, \mathrm{ArH})$, $6.59(\mathrm{~d}, J=15.5 \mathrm{~Hz}, 1 \mathrm{H}$, vinyl-H), $6.38(\mathrm{~d}, J=11.4 \mathrm{~Hz}, 1 \mathrm{H}$, vinyl-H), 6.29 (t, $J=$ $11.3 \mathrm{~Hz}, 1 \mathrm{H}$, vinyl- $\mathrm{H}$ ), 2.30 (s, $\left.3 \mathrm{H}, \mathrm{CH}_{3}\right), 2.26\left(\mathrm{~s}, 3 \mathrm{H}, \mathrm{CH}_{3}\right) .{ }^{13} \mathrm{C} \mathrm{NMR}(126 \mathrm{MHz}$, $\left.\mathrm{CDCl}_{3}\right) \delta 136.51,135.75,133.89,133.62,133.41,128.82,128.79,128.31,128.00$, 127.96, 125.44, 123.50, 20.23, 20.21. MS (EI): m/z calcd. for $\mathrm{C}_{18} \mathrm{H}_{18}$ : 234.14 GC-MS: $\mathrm{m} / \mathrm{z} 234.10$.

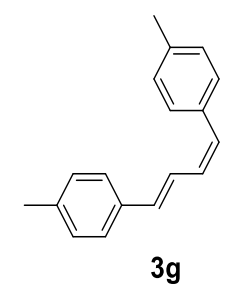

(1Z,3E)-1,4-bis(4-fluorophenyl)buta-1,3-diene (3h) ${ }^{1} \mathrm{H}$ NMR (500 MHz, $\left.\mathrm{CDCl}_{3}\right) \delta$ 7.31-7.23 (m, 4H, ArH), 7.10-7.05 (m, 2H, ArH), 7.10-7.05 (m, 1H, ArH; 1H, vinyl-H), 6.95-6.91 (m, 2H, ArH), $6.60(\mathrm{~d}, J=15.5 \mathrm{~Hz}, 1 \mathrm{H}$, vinyl-H), $6.40(\mathrm{~d}, J=$ $11.4 \mathrm{~Hz}, 1 \mathrm{H}$, vinyl-H), 6.31 (t, $J=11.2 \mathrm{~Hz}, 1 \mathrm{H}$, vinyl-H). ${ }^{13} \mathrm{C}$ NMR $(126 \mathrm{MHz}$, 
$\left.\mathrm{CDCl}_{3}\right) \delta 161.38(\mathrm{~d}, J=248.2 \mathrm{~Hz}), 160.84(\mathrm{~d}, J=247.46 \mathrm{~Hz}), 132.73,132.61(\mathrm{~d}, J=$ $3.3 \mathrm{~Hz}), 132.36(\mathrm{~d}, J=3.4 \mathrm{~Hz}), 129.57(\mathrm{~d}, J=7.9 \mathrm{~Hz}), 129.05,128.18,127.04(\mathrm{~d}, J=$ $8.0 \mathrm{~Hz}), 123.51(\mathrm{~d}, J=2.4 \mathrm{~Hz}), 114.61(\mathrm{~d}, J=21.7 \mathrm{~Hz}), 114.31(\mathrm{~d}, J=21.4 \mathrm{~Hz}) . \mathrm{MS}$ (EI): m/z calcd. for $\mathrm{C}_{16} \mathrm{H}_{12} \mathrm{~F}_{2}: 242.09$ GC-MS: m/z 242.10.

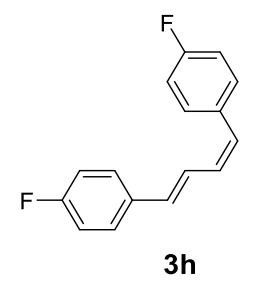

(1Z,3E)-1,4-bis(4-methoxyphenyl)buta-1,3-diene (3i) ${ }^{1} \mathrm{H}$ NMR $\left(500 \mathrm{MHz}, \mathrm{CDCl}_{3}\right) \delta$ 7.35-7.33 (m, 4H, ArH), 7.21 (dd, $J=15.2,11.4 \mathrm{~Hz}, 1 \mathrm{H}$, vinyl-H), 6.92 (d, $J=8.2 \mathrm{~Hz}$, 1H, ArH), $6.86(\mathrm{~d}, J=8.2 \mathrm{~Hz}, 1 \mathrm{H}, \mathrm{ArH}), 6.64(\mathrm{~d}, J=15.5 \mathrm{~Hz}, 1 \mathrm{H}$, vinyl-H), 6.41 (d, $J=11.3 \mathrm{~Hz}, 1 \mathrm{H}$, vinyl-H), $6.32\left(\mathrm{t}, J=11.1 \mathrm{~Hz}, 1 \mathrm{H}\right.$, vinyl-H), $3.85\left(\mathrm{~s}, 3 \mathrm{H}, \mathrm{CH}_{3}\right), 3.81$ (s, $\left.3 \mathrm{H}, \mathrm{CH}_{3}\right) .{ }^{13} \mathrm{C} \mathrm{NMR}(126 \mathrm{MHz}, \mathrm{CDCl} 3) \delta 158.25,157.58,132.75,129.54,129.27$, 128.13, 127.85, 126.71, 126.44, 122.44, 113.09, 112.78, 54.29. MS (EI): m/z calcd. for $\mathrm{C}_{18} \mathrm{H}_{18} \mathrm{O}_{2}: 266.13$ GC-MS: m/z 266.05.

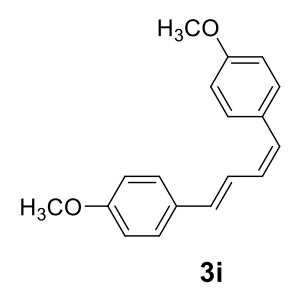

(1Z,3E)-1,4-bis(4-(trifluoromethyl)phenyl)buta-1,3-diene (3j) ${ }^{22}{ }^{1} \mathrm{H}$ NMR (500 MHz, $\left.\mathrm{CDCl}_{3}\right) \delta 7.65(\mathrm{~d}, J=8.1 \mathrm{~Hz}, 2 \mathrm{H}, \mathrm{ArH}), 7.57(\mathrm{~d}, J=8.3 \mathrm{~Hz}, 2 \mathrm{H}, \mathrm{ArH}), 7.48(\mathrm{~m}, 4 \mathrm{H}$, ArH), 7.33-7.28 (m, 1H, vinyl-H), 6.78 (d, $J=15.5 \mathrm{~Hz}, 1 \mathrm{H}$, vinyl-H), 6.61 (d, $J=$ $11.5 \mathrm{~Hz}, 1 \mathrm{H}$, vinyl-H), $6.53\left(\mathrm{t}, J=11.3 \mathrm{~Hz}, 1 \mathrm{H}\right.$, vinyl-H). ${ }^{13} \mathrm{C}$ NMR (126 MHz, $\left.\mathrm{CDCl}_{3}\right) \delta 139.82(\mathrm{~d}, J=1.3 \mathrm{~Hz}), 139.34(\mathrm{~d}, J=1.2 \mathrm{~Hz}), 133.45,130.54,129.29$, 128.21, 125.74, 125.67, 124.63 (q, $J=3.8 \mathrm{~Hz}), 124.38$ (q, $J=3.8 \mathrm{~Hz}) . \mathrm{MS}(\mathrm{EI}): \mathrm{m} / \mathrm{z}$ calcd. for $\mathrm{C}_{18} \mathrm{H}_{12} \mathrm{~F}_{6}: 342.08$ GC-MS: m/z 342.05.

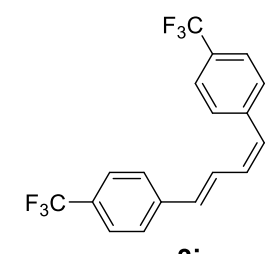

3j 
(1Z,3Z)-1,4-bis(4-(trifluoromethyl)phenyl)buta-1,3-diene (3j') ${ }^{1} \mathrm{H}$ NMR (500 MHz, $\left.\mathrm{CDCl}_{3}\right) \delta 7.63(\mathrm{~d}, J=8.1 \mathrm{~Hz}, 4 \mathrm{H}, \mathrm{ArH}), 7.50(\mathrm{~d}, J=8.1 \mathrm{~Hz}, 4 \mathrm{H}, \mathrm{ArH}), 6.76-6.69(\mathrm{~m}$, 2H, vinyl-H), 6.69-6.59 (m, 2H, vinyl-H). $\left.{ }^{13} \mathrm{C} \mathrm{NMR} \mathrm{(126} \mathrm{MHz,} \mathrm{CDCl}_{3}\right) \delta 139.43(\mathrm{~d}, J$ $=1.2 \mathrm{~Hz}), 130.72,128.30,126.62,124.24(\mathrm{q}, J=3.7 \mathrm{~Hz}) . \mathrm{MS}(\mathrm{EI}): \mathrm{m} / \mathrm{z}$ calcd. for $\mathrm{C}_{18} \mathrm{H}_{12} \mathrm{~F}_{6}: 342.08$ GC-MS: m/z 342.10.

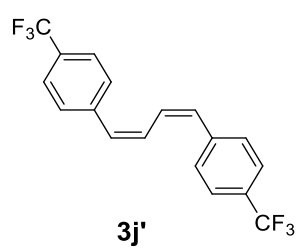

(1Z,3E)-1,4-bis(4-(tert-butyl)phenyl)buta-1,3-diene (3k) ${ }^{1} \mathrm{H}$ NMR (500 MHz, $\left.\mathrm{CDCl}_{3}\right)$ $\delta 7.41(\mathrm{~d}, J=8.3 \mathrm{~Hz}, 2 \mathrm{H}, \mathrm{ArH}), 7.39-7.31(\mathrm{~m}, 6 \mathrm{H}, \mathrm{ArH}, 1 \mathrm{H}$, vinyl-H), 6.69 (d, $J=$ $15.5 \mathrm{~Hz}, 1 \mathrm{H}$, vinyl-H), 6.47 (d, $J=11.4 \mathrm{~Hz}, 1 \mathrm{H}$, vinyl-H), 6.38 (t, $J=11.2 \mathrm{~Hz}$, $\left.1 \mathrm{H}_{\text {vinyl }}\right), 1.36$ (s, 9H, $\mathrm{CH}_{3}$ ), 1.32 (s, 9H, $\left.\mathrm{CH}_{3}\right) .{ }^{13} \mathrm{C} \mathrm{NMR}(126 \mathrm{MHz}, \mathrm{CDCl} 3) \delta 149.77$, 148.99 , 133.91, 133.68, 133.30, 128.92, 128.68, 127.80, 125.29, 124.53, 124.27, 123.85, 30.30, 30.24. MS (EI): m/z calcd. for $\mathrm{C}_{24} \mathrm{H}_{30}: 318.23$ GC-MS: m/z 318.20.

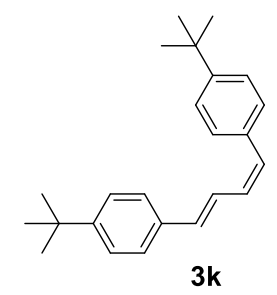

(1Z,3E)-1,4-bis(3,5-bis(trifluoromethyl)phenyl)buta-1,3-diene (3I) ${ }^{1} \mathrm{H} \quad \mathrm{NMR} \quad(500$ $\left.\mathrm{MHz}, \mathrm{CDCl}_{3}\right) \delta$ 7.80-7.68 (m, 6H, ArH), 7.67-7.52 (m, 1H, vinyl-H), 6.79 (d, $J=15.6$ $\mathrm{Hz}, 1 \mathrm{H}$, vinyl-H), $6.63(\mathrm{~d}, J=11.4 \mathrm{~Hz}, 1 \mathrm{H}$, vinyl-H), $6.56(\mathrm{t}, J=11.2 \mathrm{~Hz}, 1 \mathrm{H}$, vinyl-H). ${ }^{13} \mathrm{C}$ NMR (126 MHz, CDCl3) $\delta$ 137.85, 137.65, 132.60, 131.60, 131.38, $131,11,131.02,130.84,128.56,127.96(\mathrm{q}, J=27.72 \mathrm{~Hz}), 127.70,125.85,125.27(\mathrm{q}, J$ $=28.98 \mathrm{~Hz}), 123.28,121.10(\mathrm{q}, J=16.38 \mathrm{~Hz}), 120.46(\mathrm{q}, J=12.6 \mathrm{~Hz}), 120.06(\mathrm{q}, J=$ 15.12 Hz), 119.74 (q, $J=15.12 \mathrm{~Hz}), 93.96,93.73$. MS (EI): m/z calcd. for $\mathrm{C}_{20} \mathrm{H}_{10} \mathrm{~F}_{12}$ : 478.06 GC-MS: m/z 478.15. 


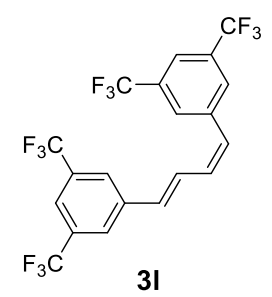

(1Z,3E)-1,4-di(naphthalen-2-yl)buta-1,3-diene (3m) ${ }^{1} \mathrm{H}$ NMR $\left(500 \mathrm{MHz}, \mathrm{CDCl}_{3}\right) \delta$ 7.89-7.85 (m, 4H, ArH), 7.80-7.74 (m, 5H, ArH), 7.62-7.53 (m, 2H, ArH), 7.54-7.52 (m, $1 \mathrm{H}_{\mathrm{Ar}}, 1 \mathrm{H}$, vinyl-H), 7.47-7.41 (m, 2H, ArH), 6.93 (d, J = 15.4 Hz, 1H, vinyl-H), $6.71\left(\mathrm{~d}, J=11.3 \mathrm{~Hz}, 1 \mathrm{H}\right.$, vinyl-H), $6.58\left(\mathrm{~d}, J=11.3 \mathrm{~Hz}, 1 \mathrm{H}\right.$, vinyl-H). ${ }^{13} \mathrm{C}$ NMR $(126$ $\mathrm{MHz}, \mathrm{CDCl} 3) \delta 134.28,134.23,133.84,132.43,132.08,129.78,129.54,127.27$, $127.06,127.00,126.66,126.65,126.25,125.69$, 125.33, 125.27, 125.00, 124.96, , 124.66, 122.56. MS (EI): m/z calcd. for $\mathrm{C}_{24} \mathrm{H}_{18}: 306.14$ GC-MS: m/z 305.80.

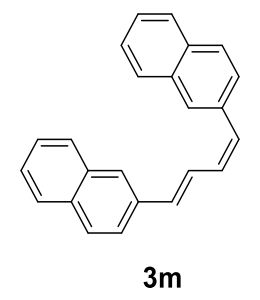

(1Z,3E)-1,4-di(thiophen-3-yl)buta-1,3-diene (3n) ${ }^{1} \mathrm{H}$ NMR $\left(500 \mathrm{MHz}, \mathrm{CDCl}_{3}\right) \delta$ 7.37-7.35 (m, 1H, ArH), 7.32-7.31 (m, 1H, ArH), 7.29 (s, 1H, ArH), 7.28-7.26 (m, 1H, ArH), 7.24-7.21 (m, 2H, ArH, 1H, vinyl-H), 6.75 (d, $J=15.5 \mathrm{~Hz}, 1 \mathrm{H}$, vinyl-H), 6.44 $\left(\mathrm{d}, J=11.3 \mathrm{~Hz}, 1 \mathrm{H}\right.$, vinyl-H), 6.33 (t, $J=11.3 \mathrm{~Hz}, 1 \mathrm{H}$, vinyl-H). ${ }^{13} \mathrm{C}$ NMR $(126 \mathrm{MHz}$, $\left.\mathrm{CDCl}_{3}\right) \delta 139.14,137.82,128.45,127.55,127.50,125.17,124.50,124.45,124.01$, 122.76, 122.47, 121.52. MS (EI): m/z calcd. for $\mathrm{C}_{12} \mathrm{H}_{10} \mathrm{~S}_{2}: 218.02 \mathrm{GC}-\mathrm{MS}: \mathrm{m} / \mathrm{z}$ 218.10.

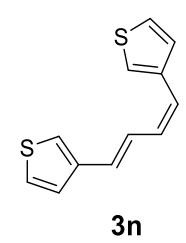

Trimethyl((1E,3Z)-4-(naphthalen-2-yl)buta-1,3-dien-1-yl)silane (3o) ${ }^{1} \mathrm{H}$ NMR (500 $\left.\mathrm{MHz}, \mathrm{CDCl}_{3}\right) \delta$ 7.82-7.74 (m, 4H, ArH), 7.67-7.57 (m, 1H, $\left.\mathrm{ArH}\right), 7.49-7.41(\mathrm{~m}, 2 \mathrm{H}$, ArH), 7.19-7.11 (m, 1H, vinyl-H), 7.02 (dd, $J=13.9,11.2 \mathrm{~Hz}, 1 \mathrm{H}$, vinyl-H), 6.74 (d, $J=15.3 \mathrm{~Hz}, 1 \mathrm{H}$, vinyl-H), $5.79\left(\mathrm{~d}, J=13.9 \mathrm{~Hz}, 1 \mathrm{H}\right.$, vinyl-H), $0.26\left(\mathrm{~s}, 9 \mathrm{H}, \mathrm{CH}_{3}\right)$. 
MS (EI): m/z calcd. for $\mathrm{C}_{17} \mathrm{H}_{20} \mathrm{Si}: 252.13$ GC-MS: m/z 252.10.

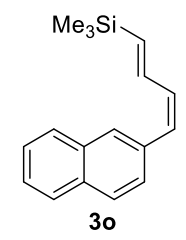

11. ${ }^{1} \mathrm{H}$ NMR and ${ }^{13} \mathrm{C}$ NMR spectra

$11.1^{1} \mathrm{H}-{ }^{1} \mathrm{H}$ COSY spectrum of $3 \mathbf{a}$

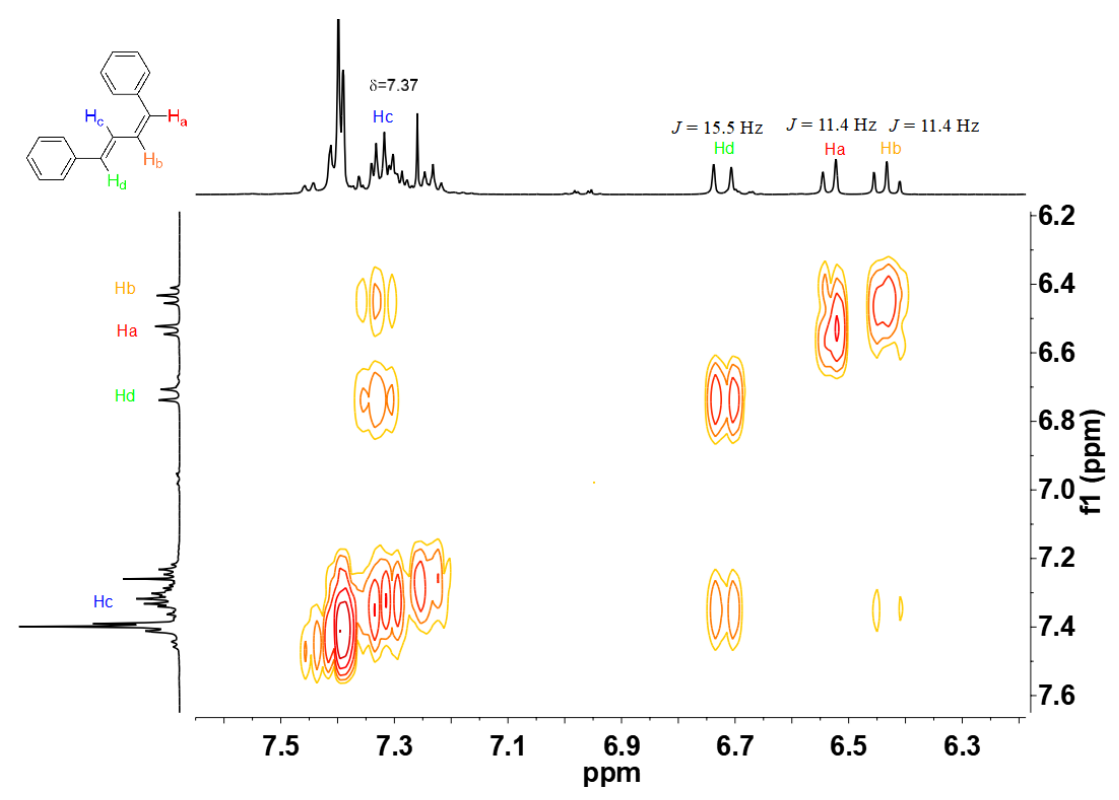

Figure S22. ${ }^{1} \mathrm{H}-{ }^{1} \mathrm{H}$ COSY spectrum of $\mathbf{3 a}$ in $\mathrm{CDCl}_{3}$ 


\section{2 ${ }^{13} \mathrm{C}-{ }^{1} \mathrm{H}$ HMBC spectrum of $5 p$}

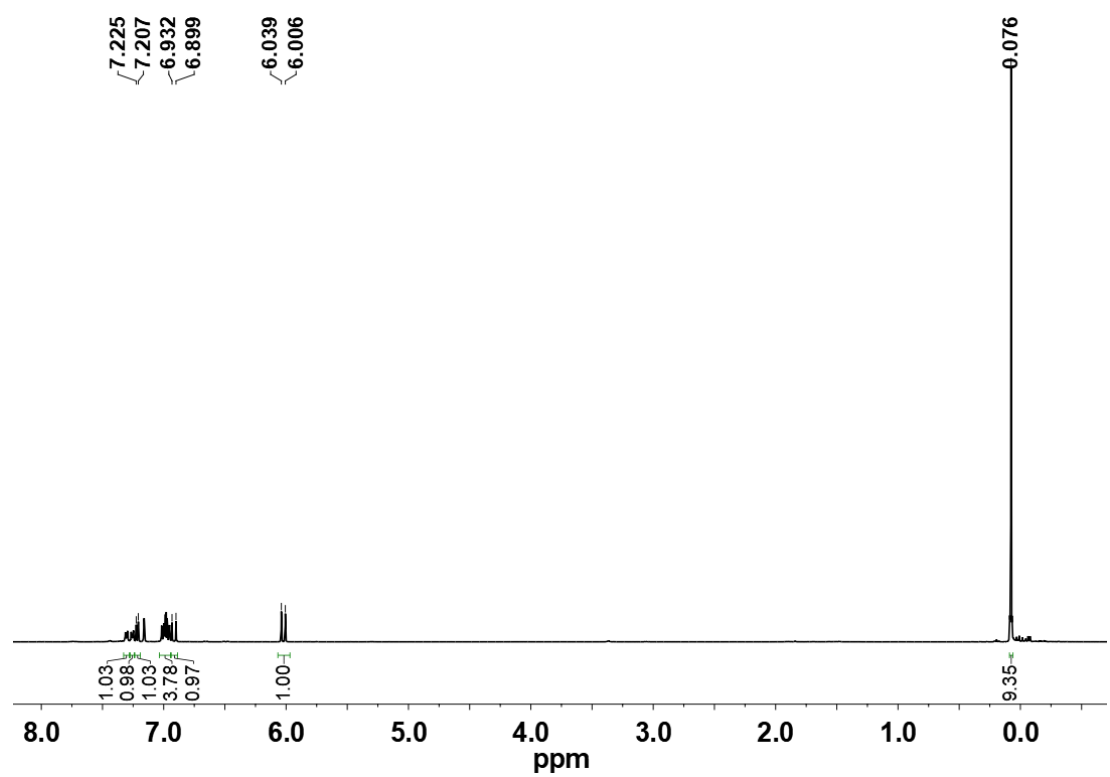

Figure S23. ${ }^{1} \mathrm{H}$ NMR spectrum of $\mathbf{5 p}$ in $\mathrm{C}_{6} \mathrm{D}_{6}$.

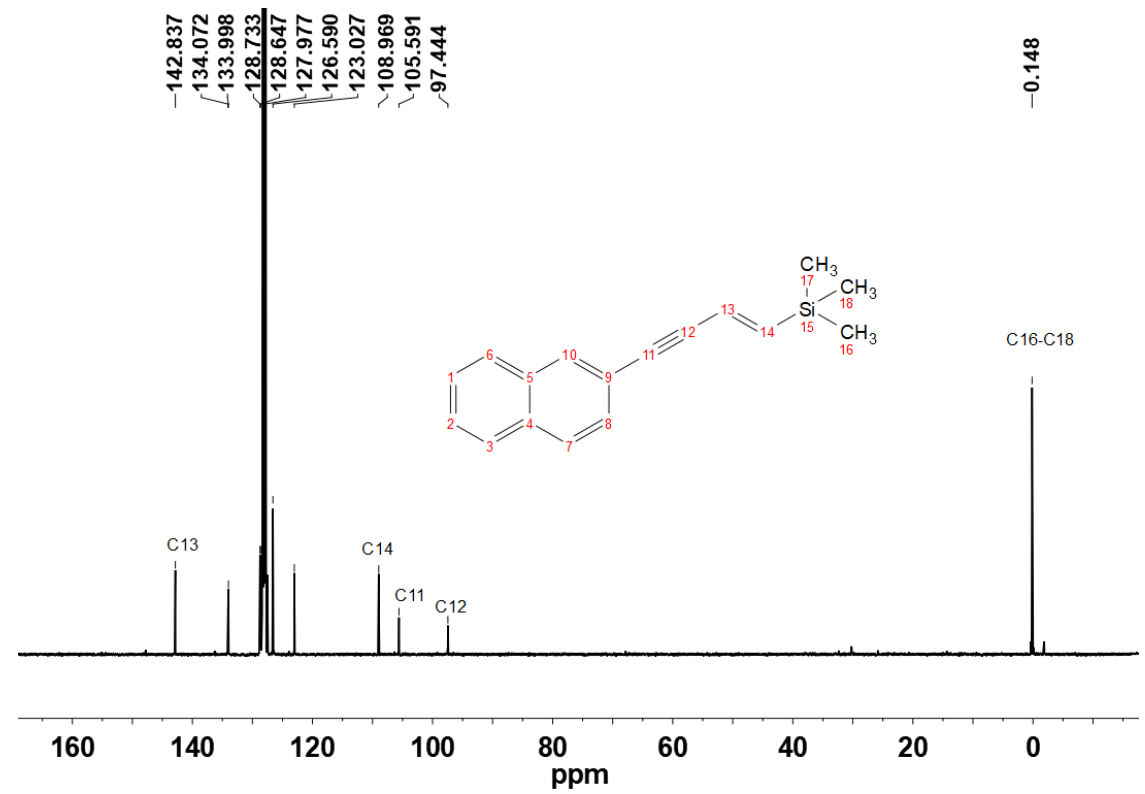

Figure S24. ${ }^{13} \mathrm{C}$ NMR spectrum of $\mathbf{5 p}$ in $\mathrm{C}_{6} \mathrm{D}_{6}$. 


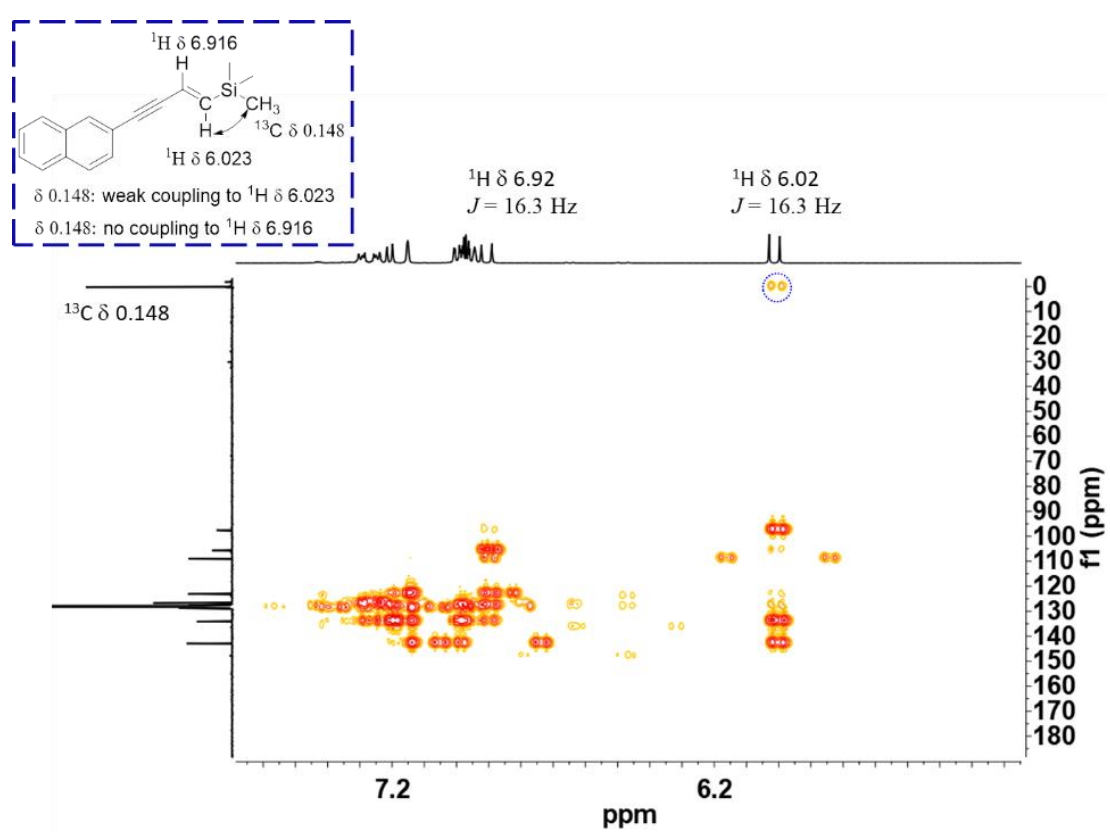

Figure S25. ${ }^{13} \mathrm{C}-{ }^{1} \mathrm{H}$ HMBC spectrum of $\mathbf{5 p}$ in $\mathrm{C}_{6} \mathrm{D}_{6}$.

\section{$11.3^{1} \mathrm{H}$ NMR of $E$-enynes.}

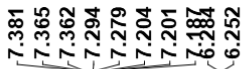

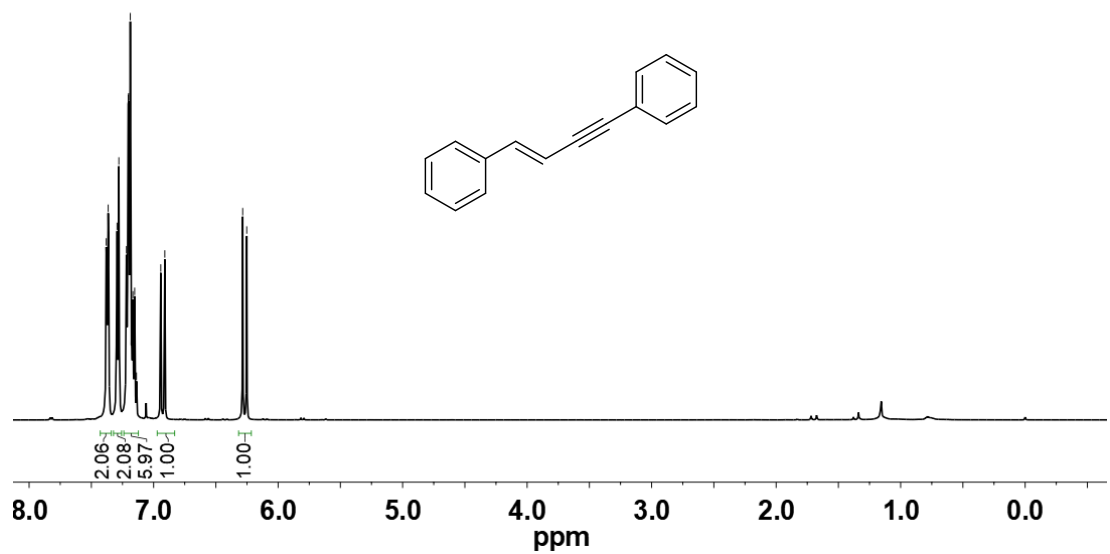

Figure S26. ${ }^{1} \mathrm{H}$ NMR spectrum of $\mathbf{5 a}$ in $\mathrm{CDCl}_{3}$. 


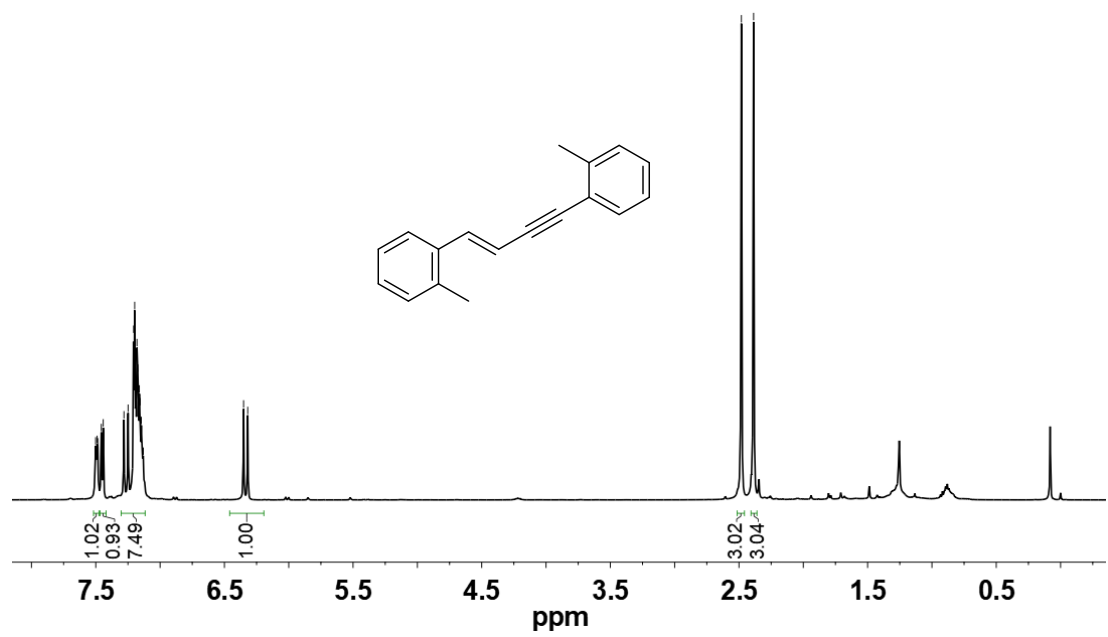

Figure S27. ${ }^{1} \mathrm{H}$ NMR spectrum of $\mathbf{5 b}$ in $\mathrm{CDCl}_{3}$.

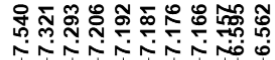

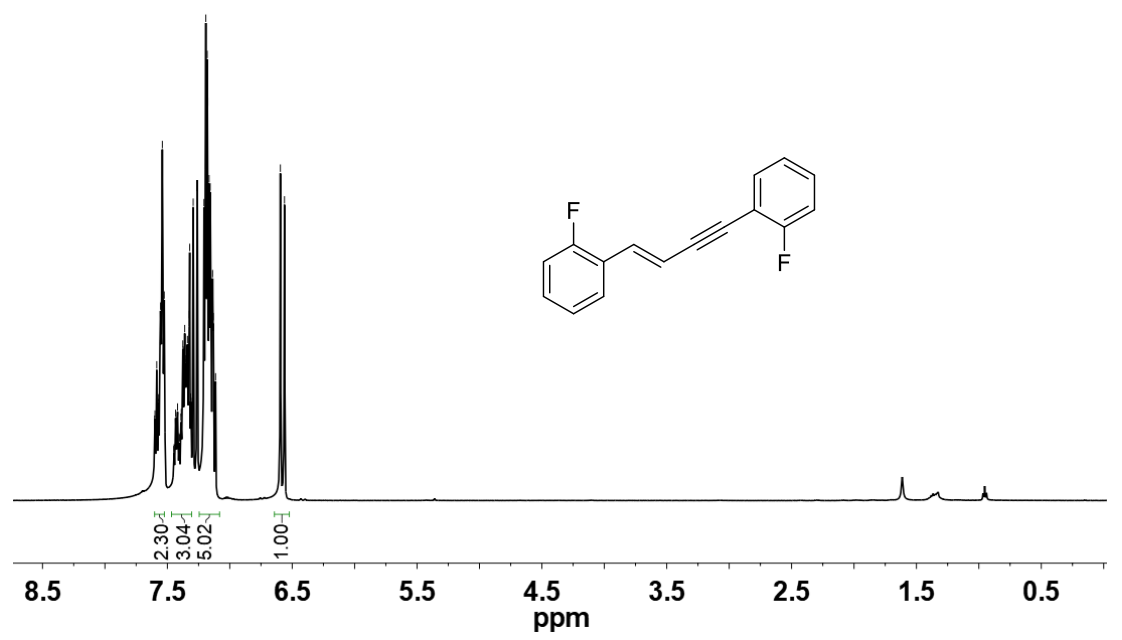

Figure S28. ${ }^{1} \mathrm{H}$ NMR spectrum of $\mathbf{5 c}$ in $\mathrm{CDCl}_{3}$. 


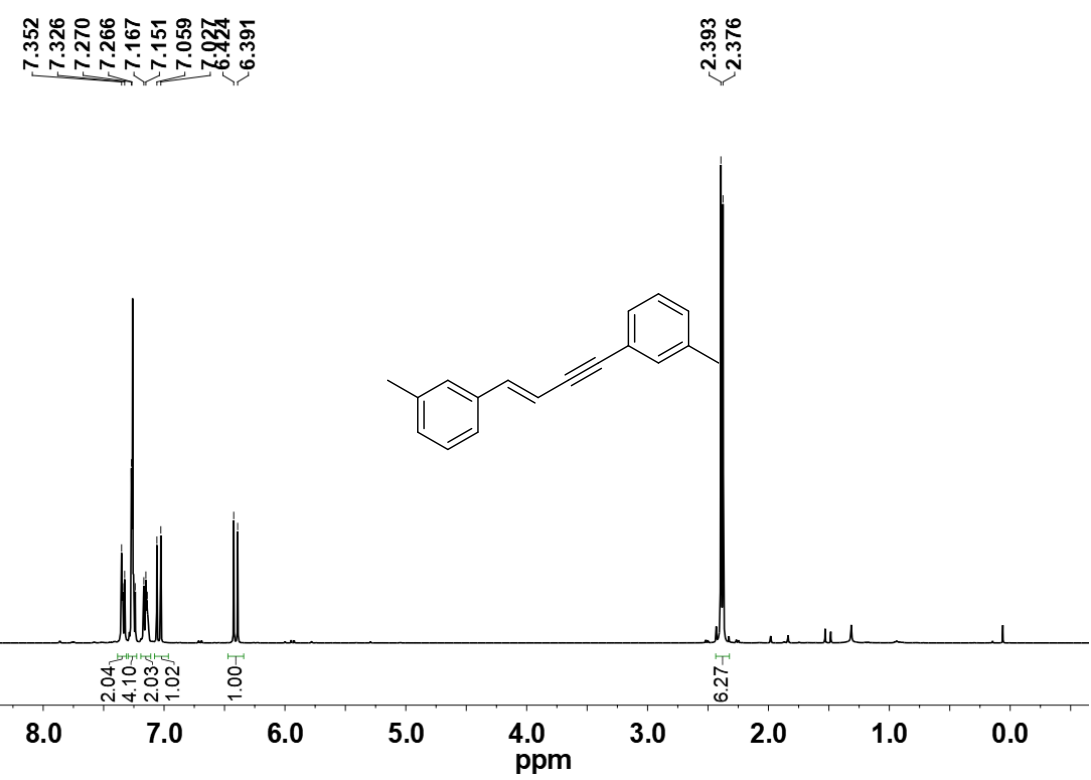

Figure S29. ${ }^{1} \mathrm{H}$ NMR spectrum of $\mathbf{5 d}$ in $\mathrm{CDCl}_{3}$.

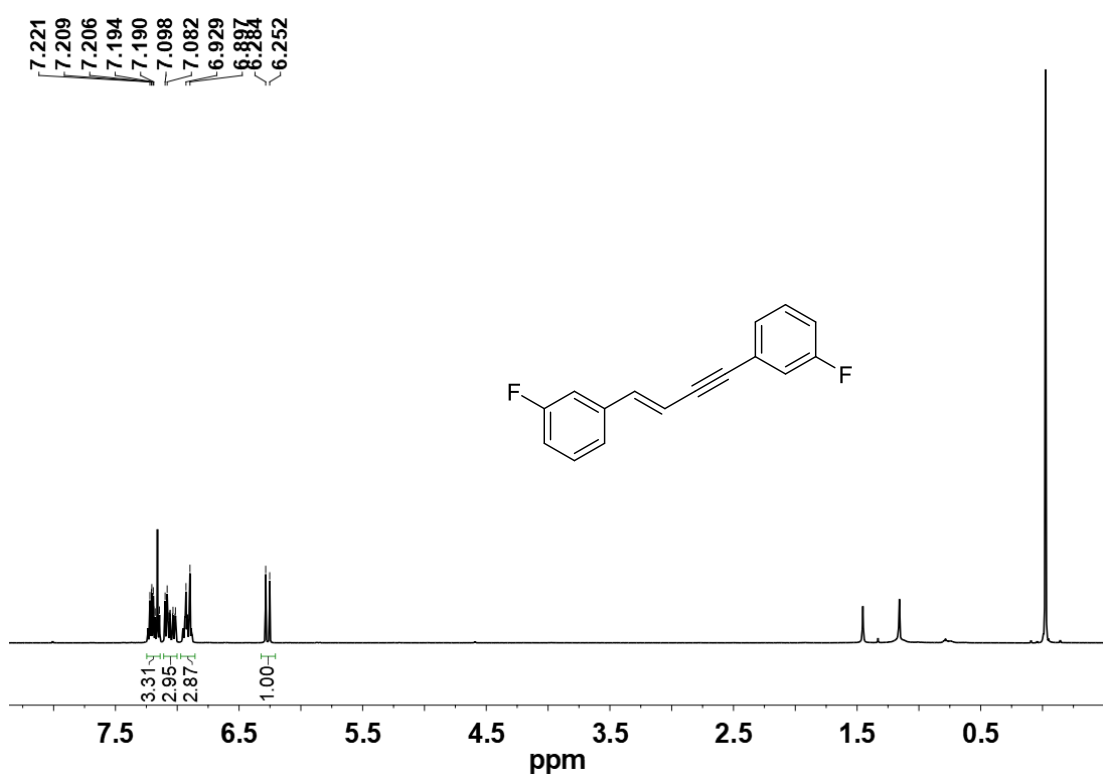

Figure S30. ${ }^{1} \mathrm{H}$ NMR spectrum of $5 \mathbf{e}$ in $\mathrm{CDCl}_{3}$. 


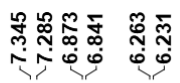

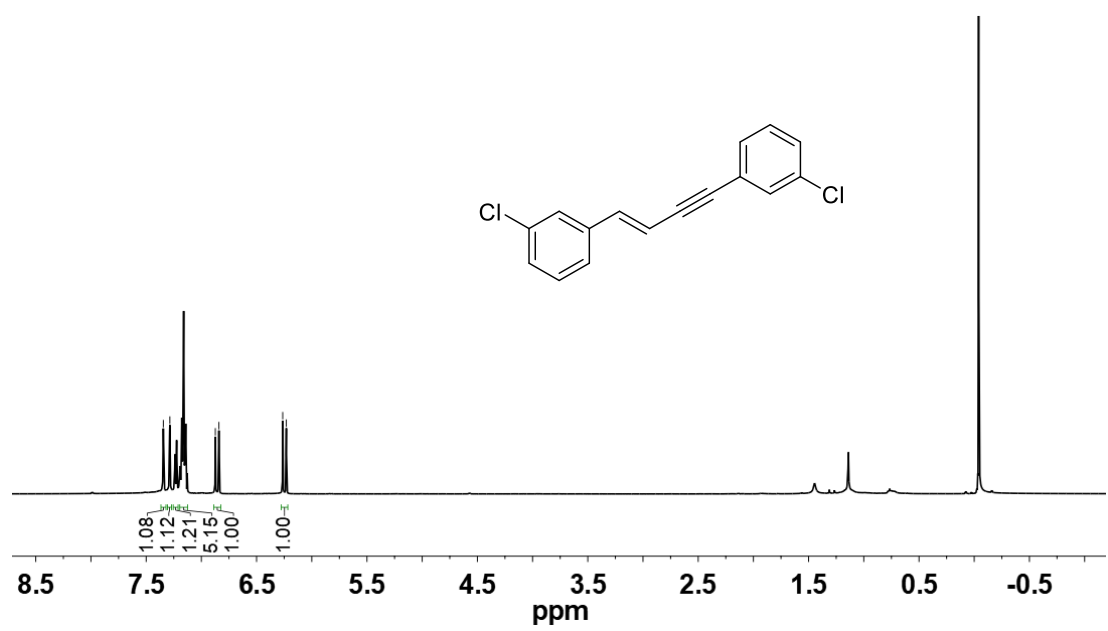

Figure S31. ${ }^{1} \mathrm{H}$ NMR spectrum of $\mathbf{5 f}$ in $\mathrm{CDCl}_{3}$.

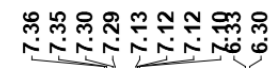

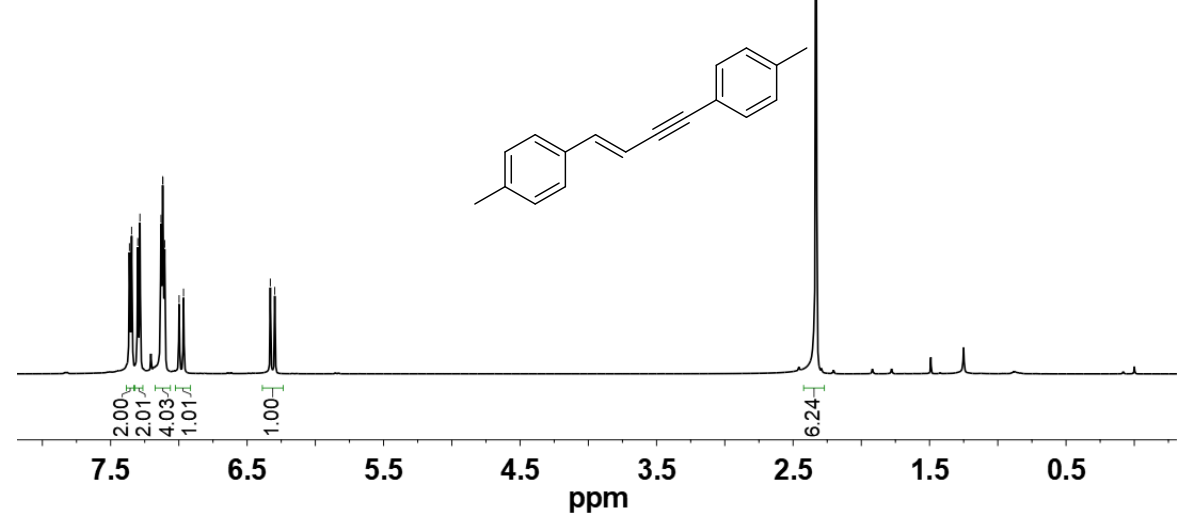

Figure S32. ${ }^{1} \mathrm{H}$ NMR spectrum of $\mathbf{5 g}$ in $\mathrm{CDCl}_{3}$. 


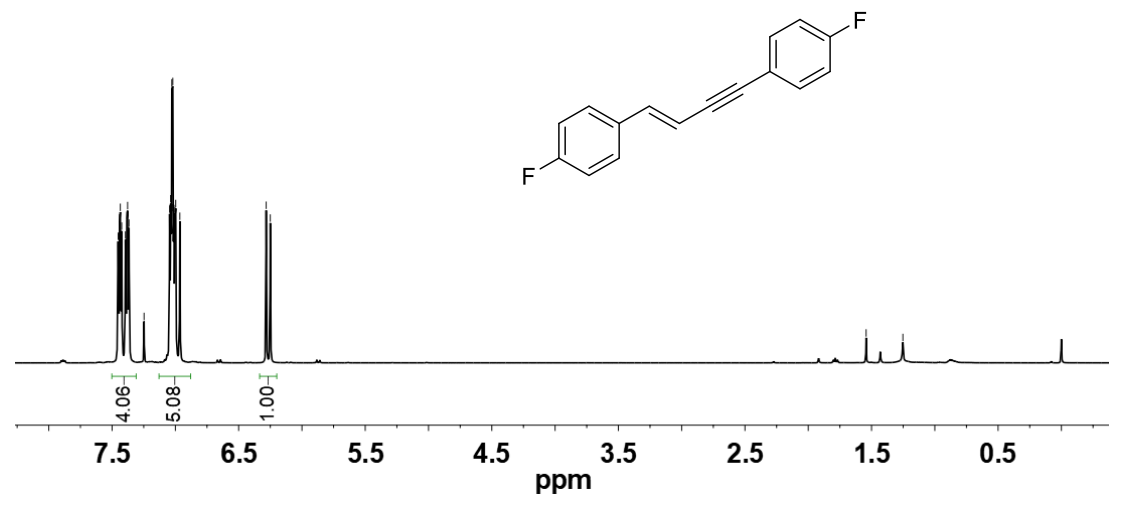

Figure S33. ${ }^{1} \mathrm{H}$ NMR spectrum of $\mathbf{5 h}$ in $\mathrm{CDCl}_{3}$.

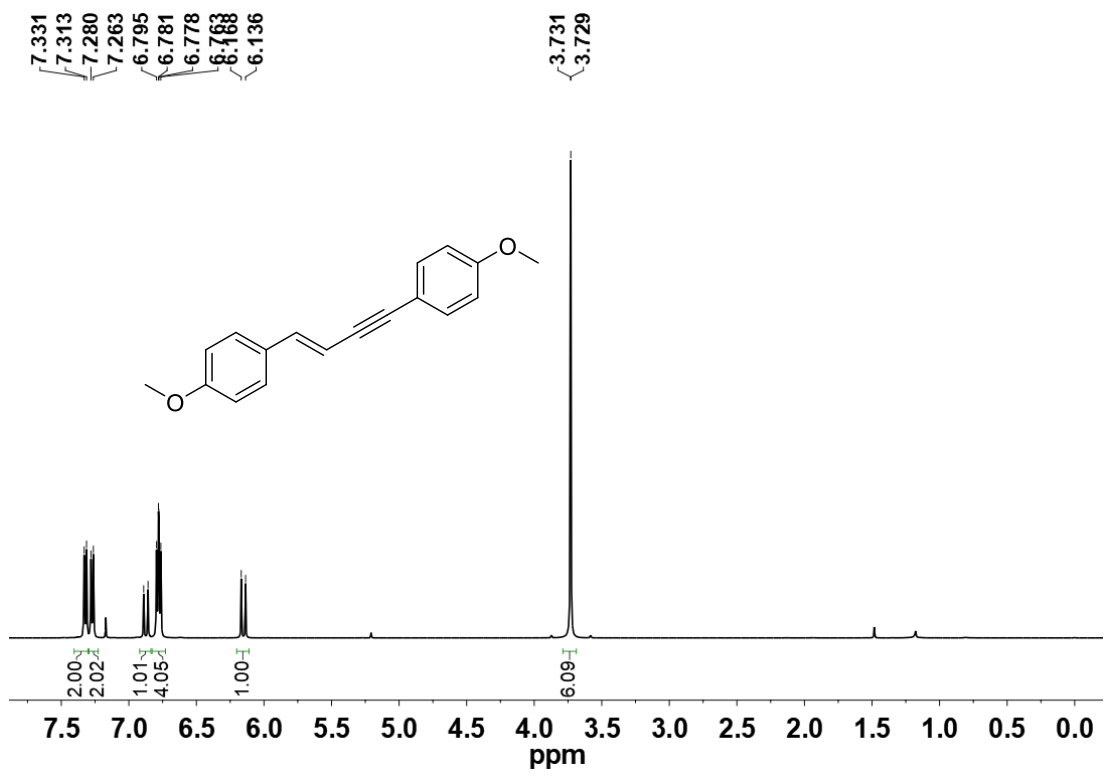

Figure S34. ${ }^{1} \mathrm{H}$ NMR spectrum of $5 \mathrm{i}$ in $\mathrm{CDCl}_{3}$ 


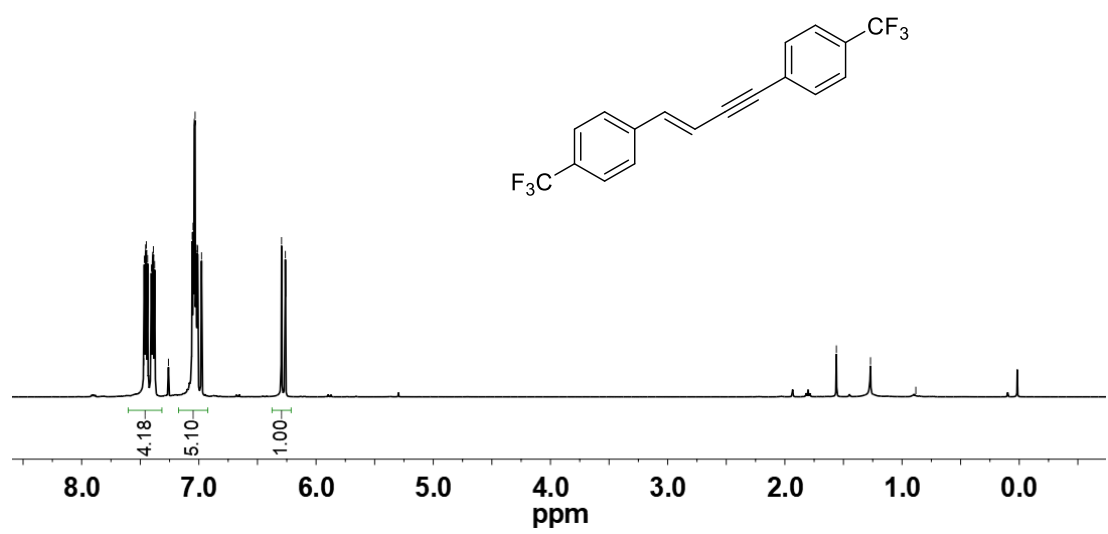

Figure S35. ${ }^{1} \mathrm{H}$ NMR spectrum of $\mathbf{5 j}$ in $\mathrm{CDCl}_{3}$.

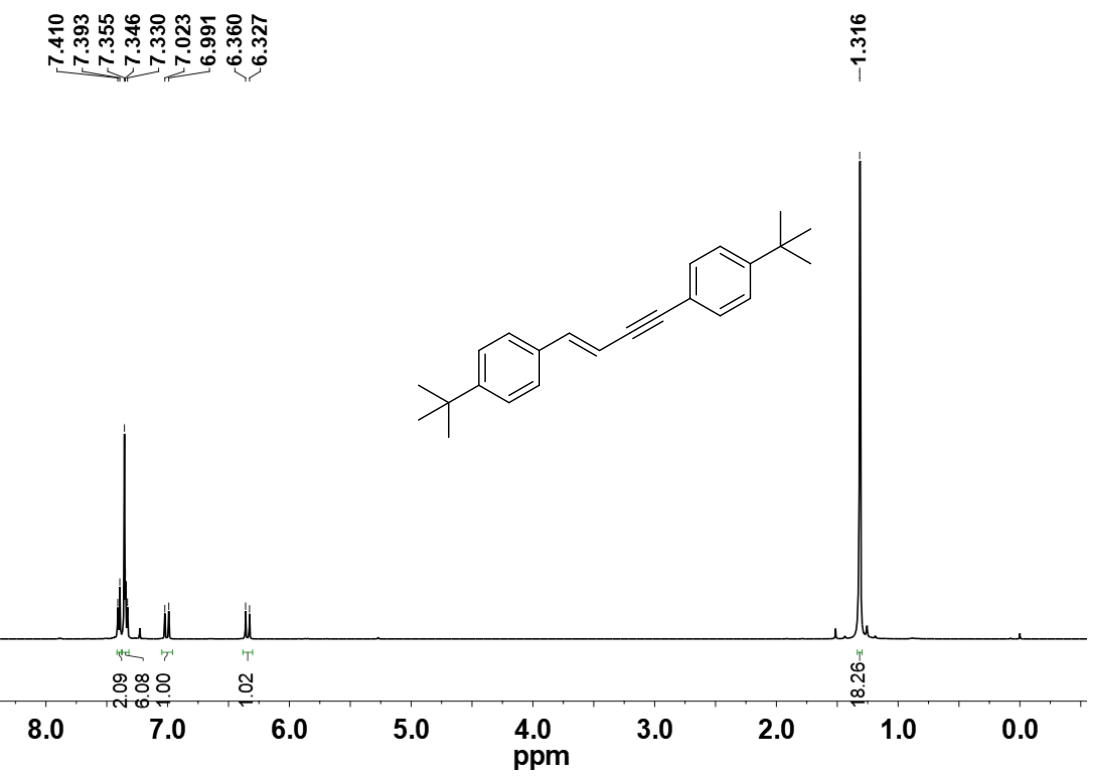

Figure S36. ${ }^{1} \mathrm{H}$ NMR spectrum of $\mathbf{5 k}$ in $\mathrm{CDCl}_{3}$. 


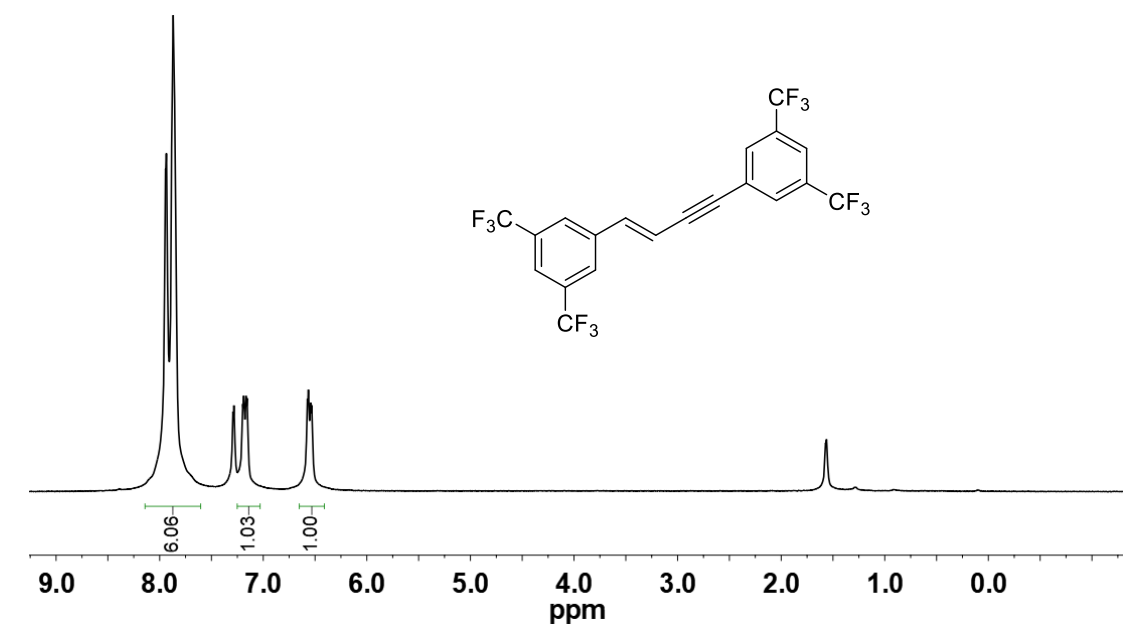

Figure S37. ${ }^{1} \mathrm{H}$ NMR spectrum of 51 in $\mathrm{CDCl}_{3}$.

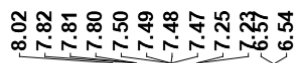

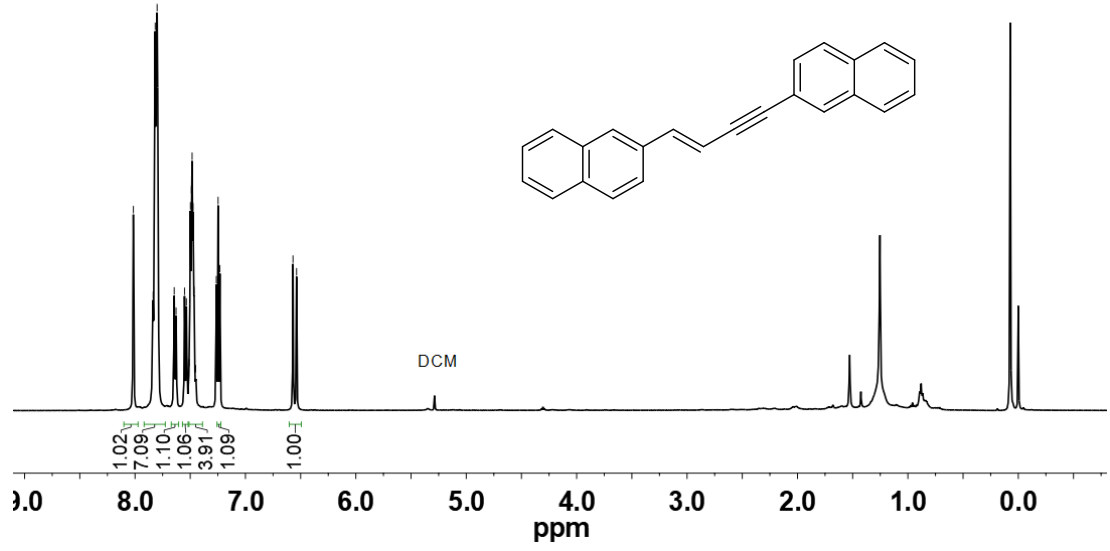

Figure S38. ${ }^{1} \mathrm{H}$ NMR spectrum of $\mathbf{5 m}$ in $\mathrm{CDCl}_{3}$.

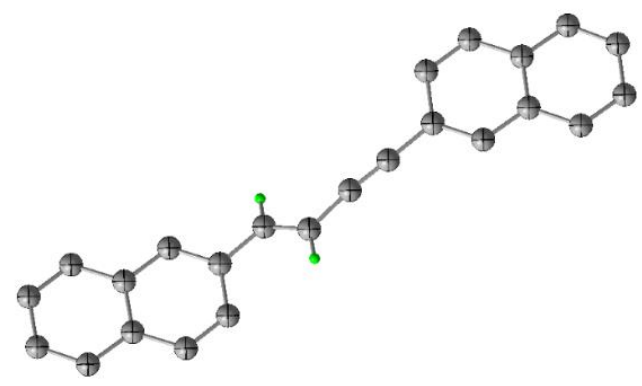

Figure S39. Crystal structure of $\mathbf{5 m}$ (50\% probability thermal ellipsoids) 


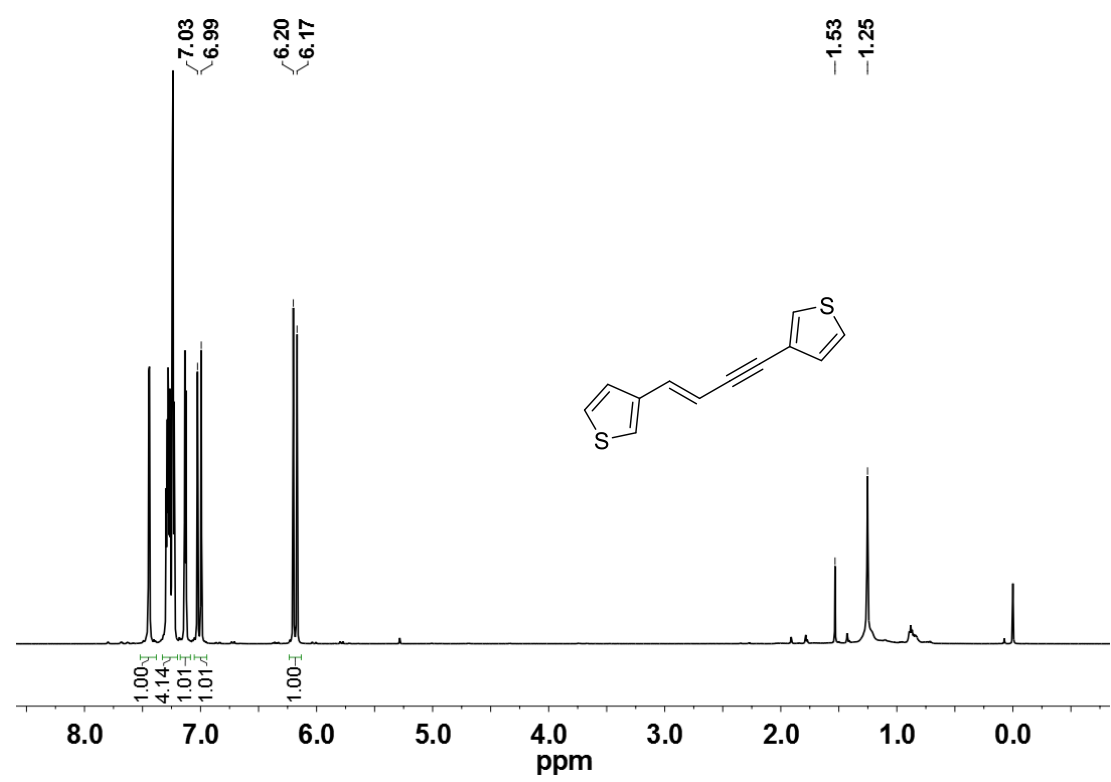

Figure S40. ${ }^{1} \mathrm{H}$ NMR spectrum of $\mathbf{5 n}$ in $\mathrm{CDCl}_{3}$.

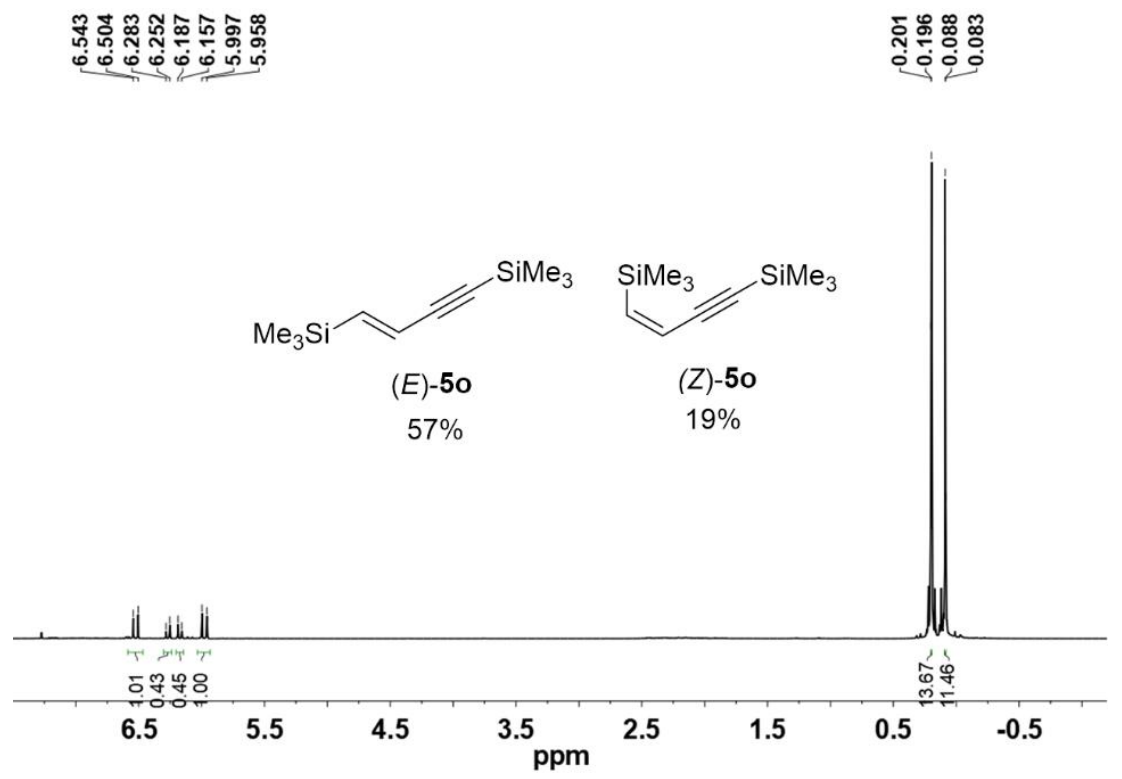

Figure S41. ${ }^{1} \mathrm{H}$ NMR spectrum of $(E)-50$ and $(Z)-50$ in $\mathrm{CDCl}_{3}$. 


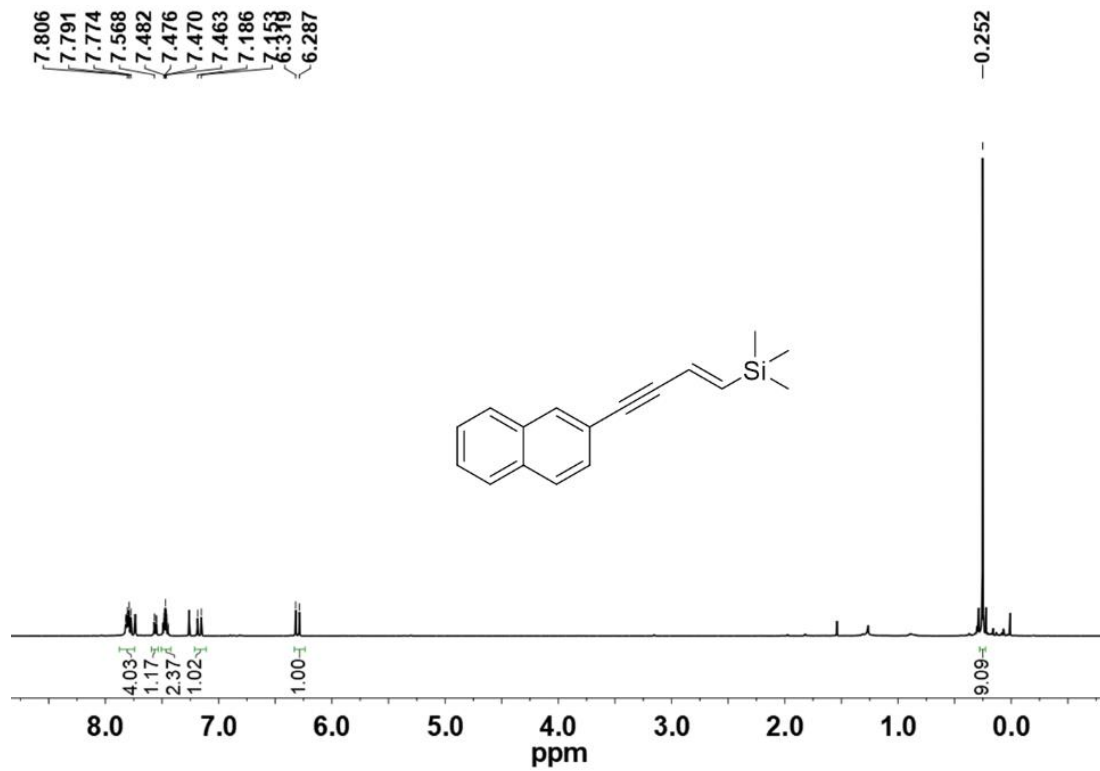

Figure S42. ${ }^{1} \mathrm{H}$ NMR spectrum of $\mathbf{5 p}$ in $\mathrm{CDCl}_{3}$. 


\section{4 ${ }^{1} \mathrm{HNMR}$ and ${ }^{13} \mathrm{CNMR}$ of dienes}

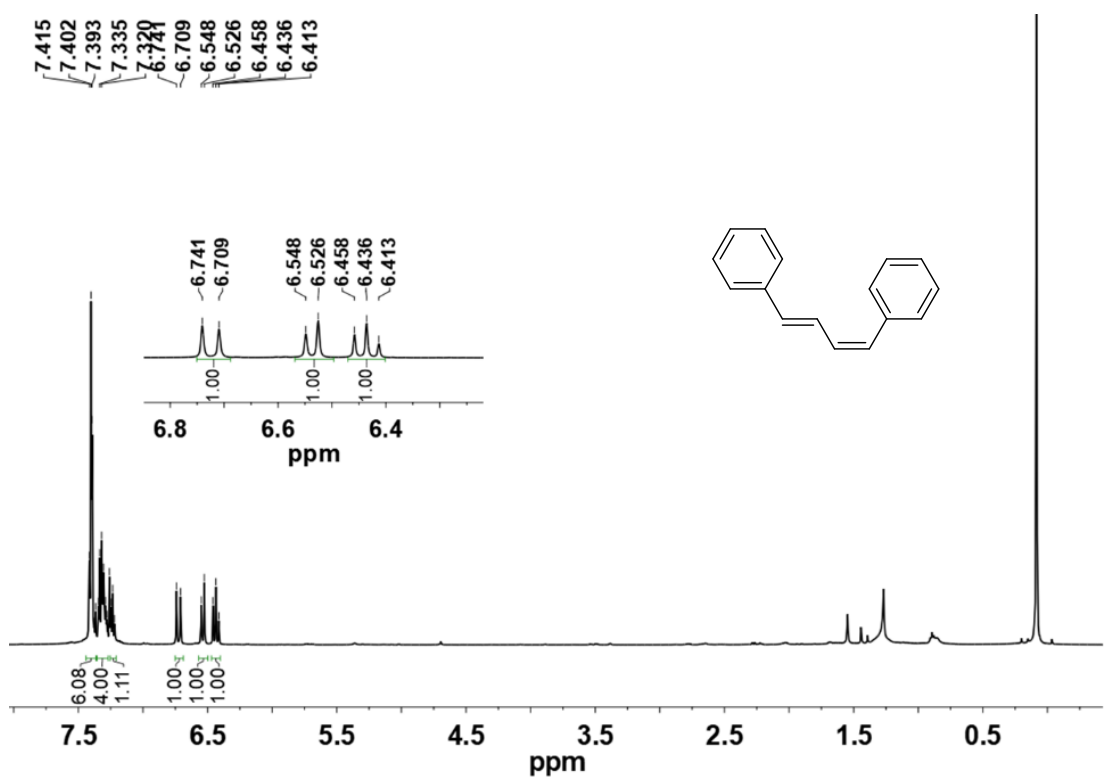

Figure S43. ${ }^{1} \mathrm{H}$ NMR spectrum of $\mathbf{3 a}$ in $\mathrm{CDCl}_{3}$.
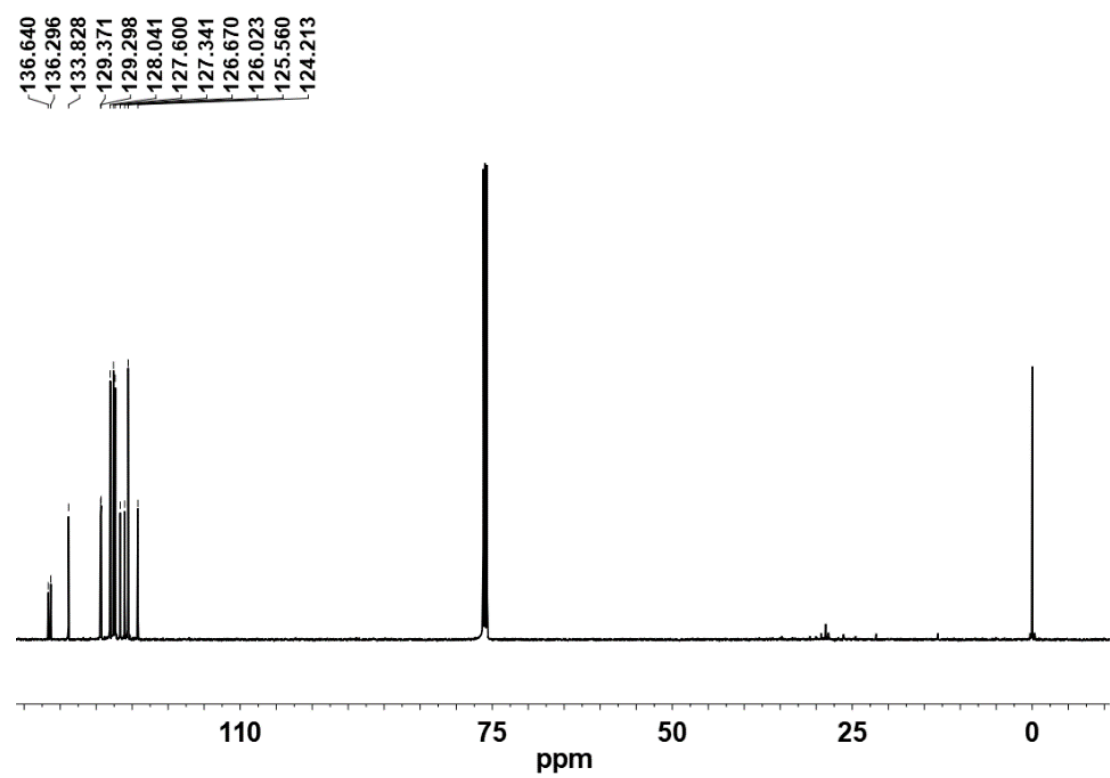

Figure S44. ${ }^{13} \mathrm{C}$ NMR spectrum of $\mathbf{3 a}$ in $\mathrm{CDCl}_{3}$. 


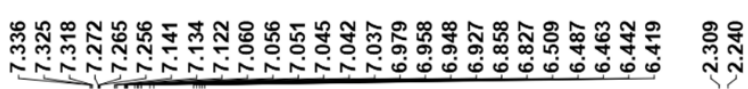

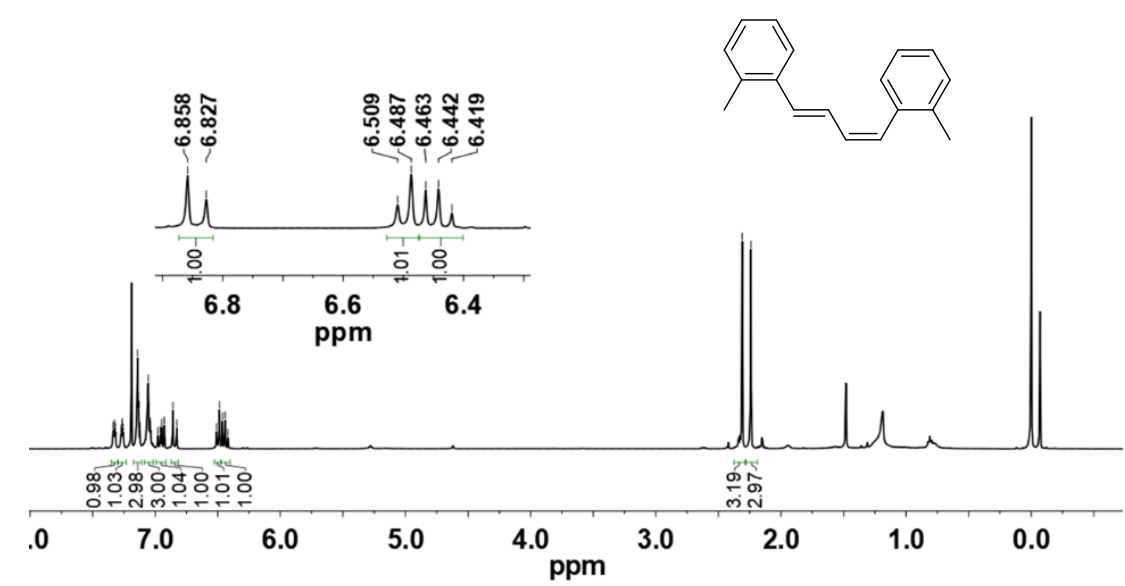

Figure S45. ${ }^{1} \mathrm{H}$ NMR spectrum of $\mathbf{3 b}$ in $\mathrm{CDCl}_{3}$.

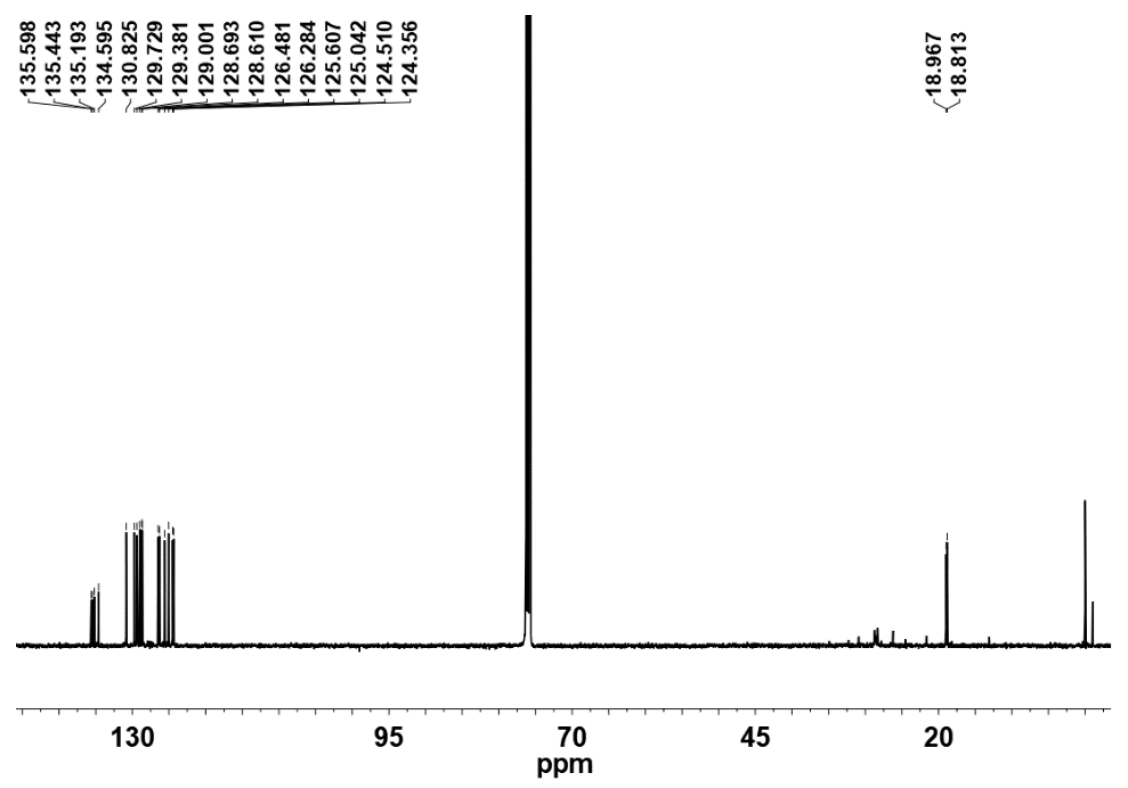

Figure S46. ${ }^{13} \mathrm{C}$ NMR spectrum of $\mathbf{3 b}$ in $\mathrm{CDCl}_{3}$. 


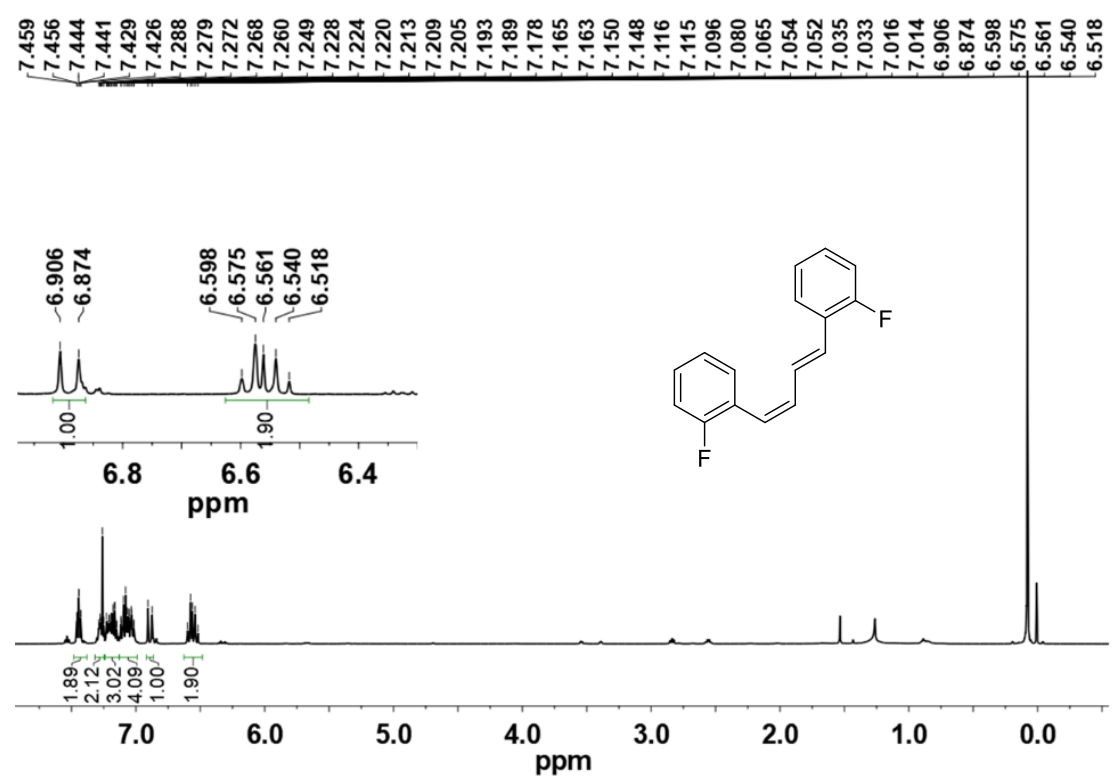

Figure S47. ${ }^{1} \mathrm{H}$ NMR spectrum of $\mathbf{3 c}$ in $\mathrm{CDCl}_{3}$.

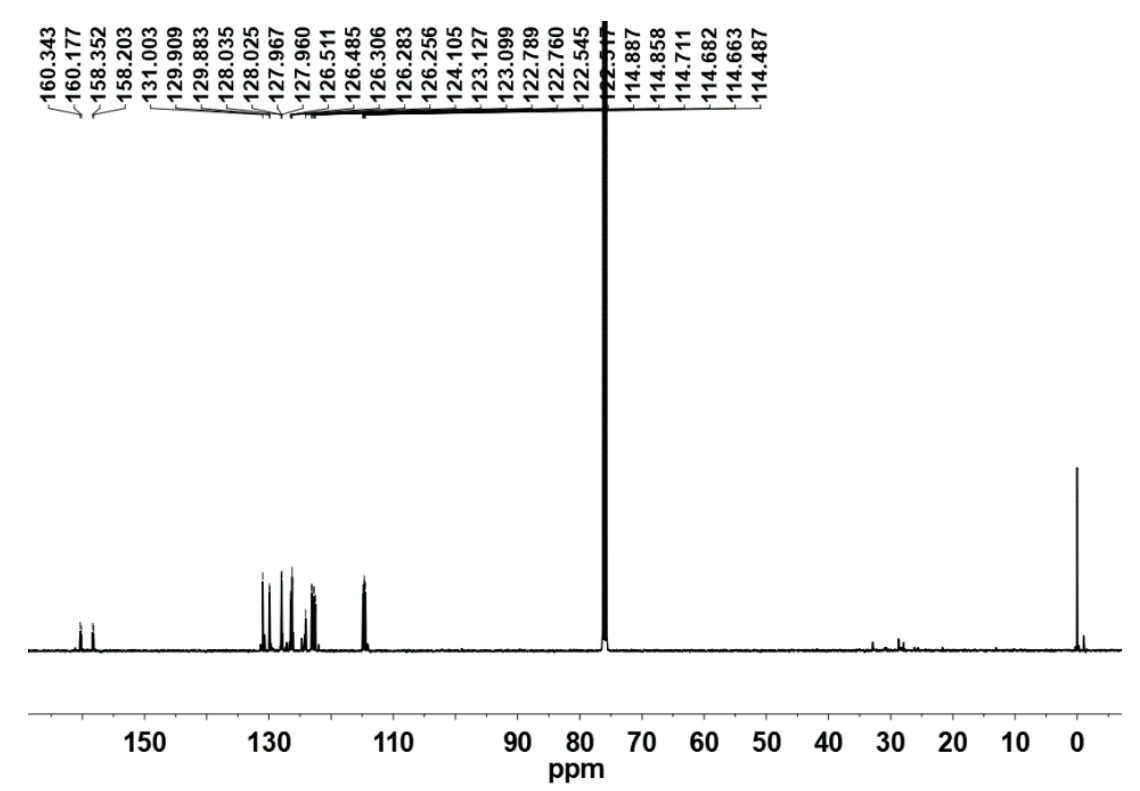

Figure S48. ${ }^{13} \mathrm{C}$ NMR spectrum of $3 \mathrm{c}$ in $\mathrm{CDCl}_{3}$. 


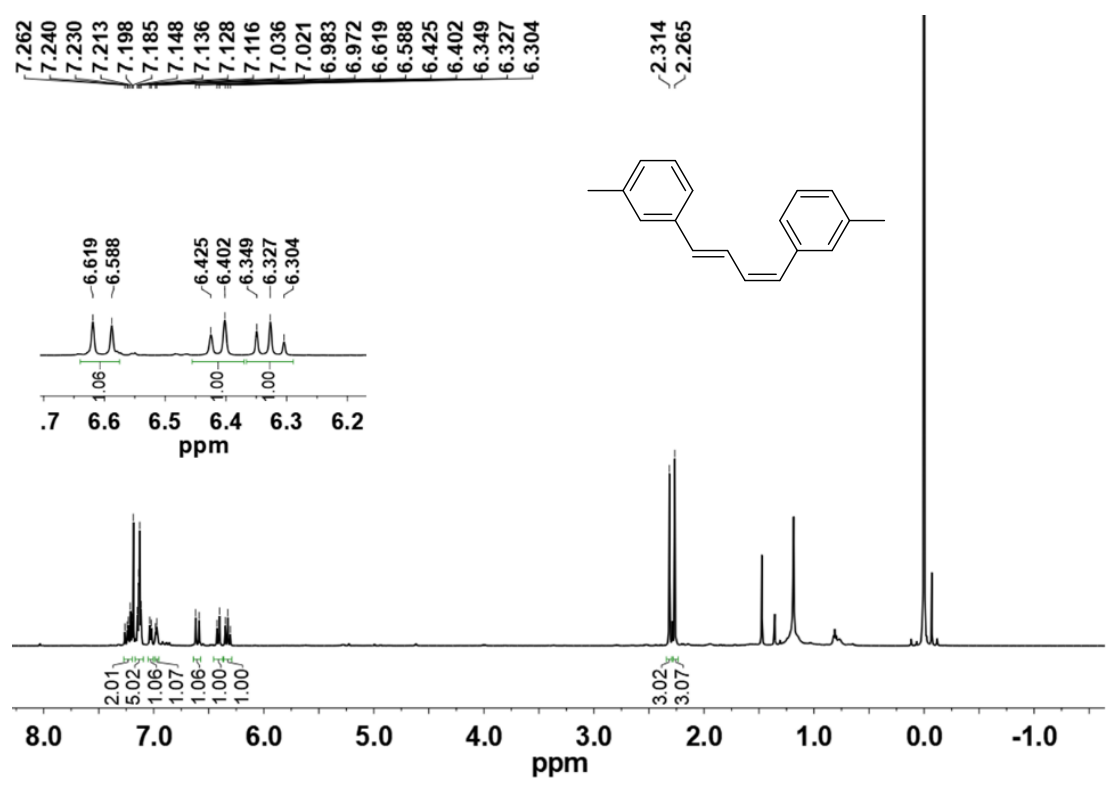

Figure S49. ${ }^{1} \mathrm{H}$ NMR spectrum of $\mathbf{3 d}$ in $\mathrm{CDCl}_{3}$.

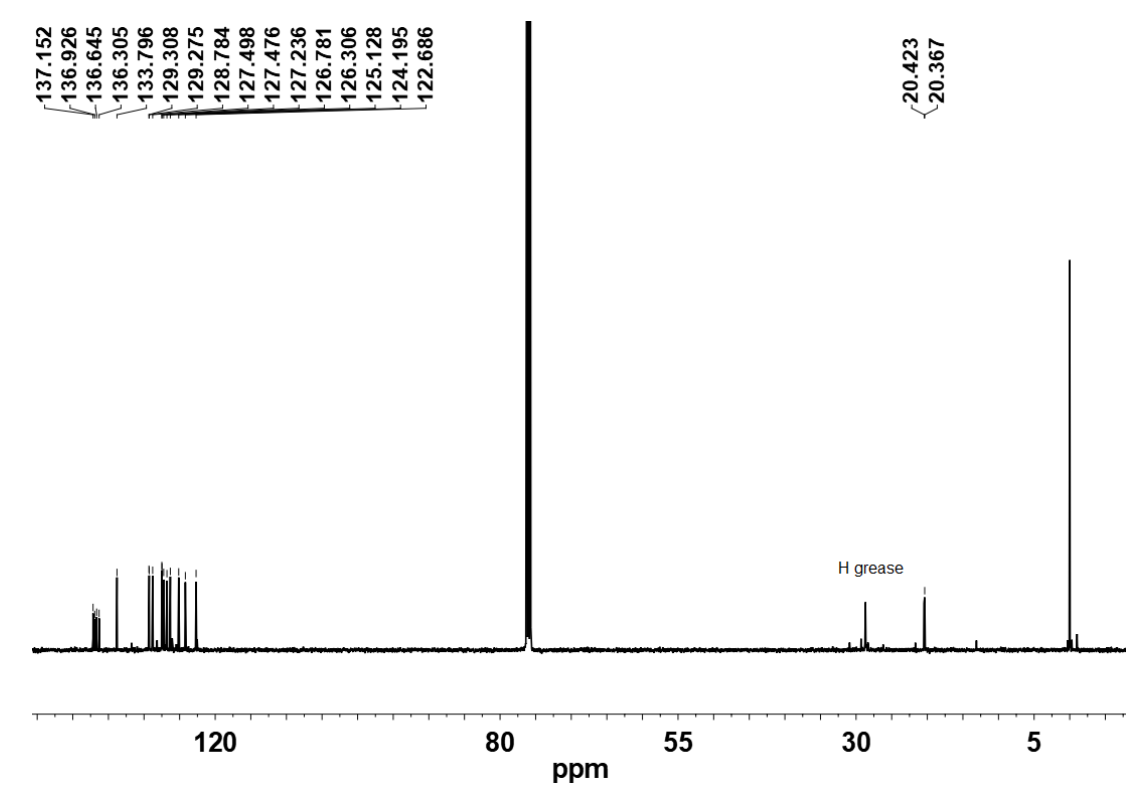

Figure S50. ${ }^{13} \mathrm{C}$ NMR spectrum of $\mathbf{3 d}$ in $\mathrm{CDCl}_{3}$. 


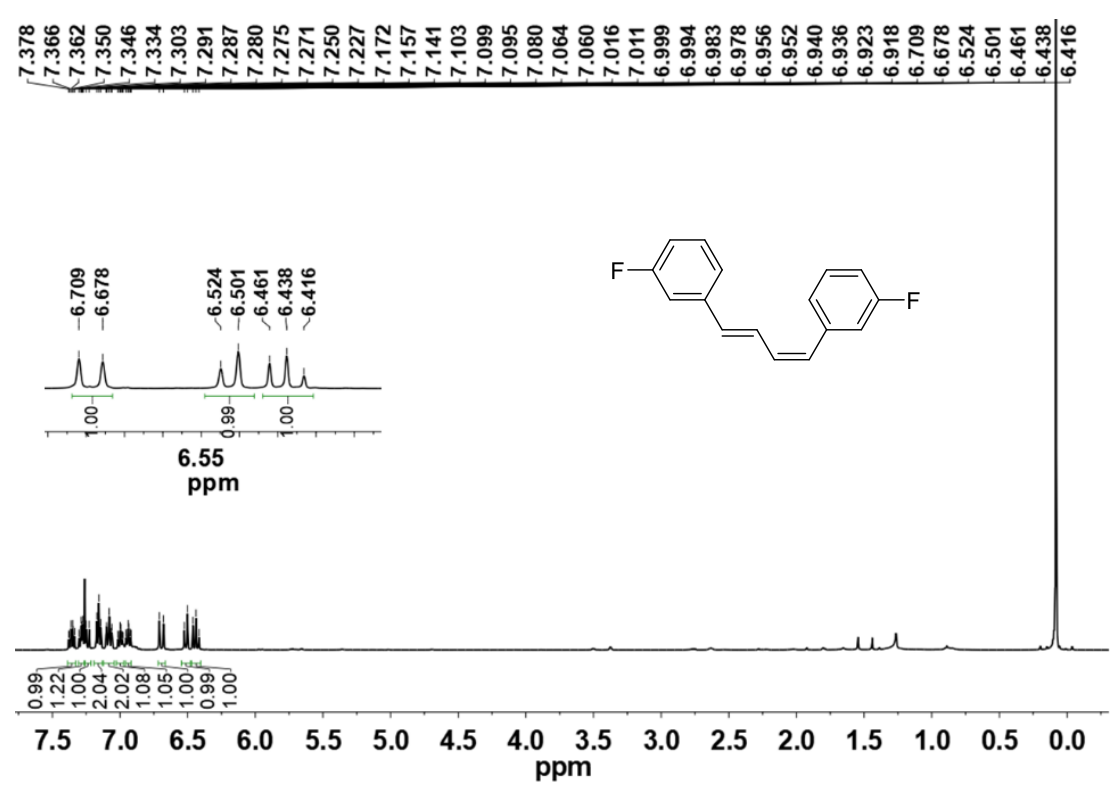

Figure S51. ${ }^{1} \mathrm{H}$ NMR spectrum of $\mathbf{3 e}$ in $\mathrm{CDCl}_{3}$.

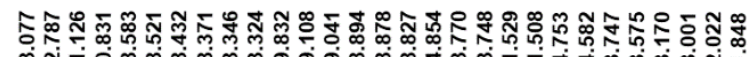

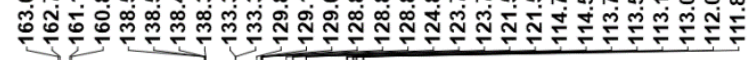

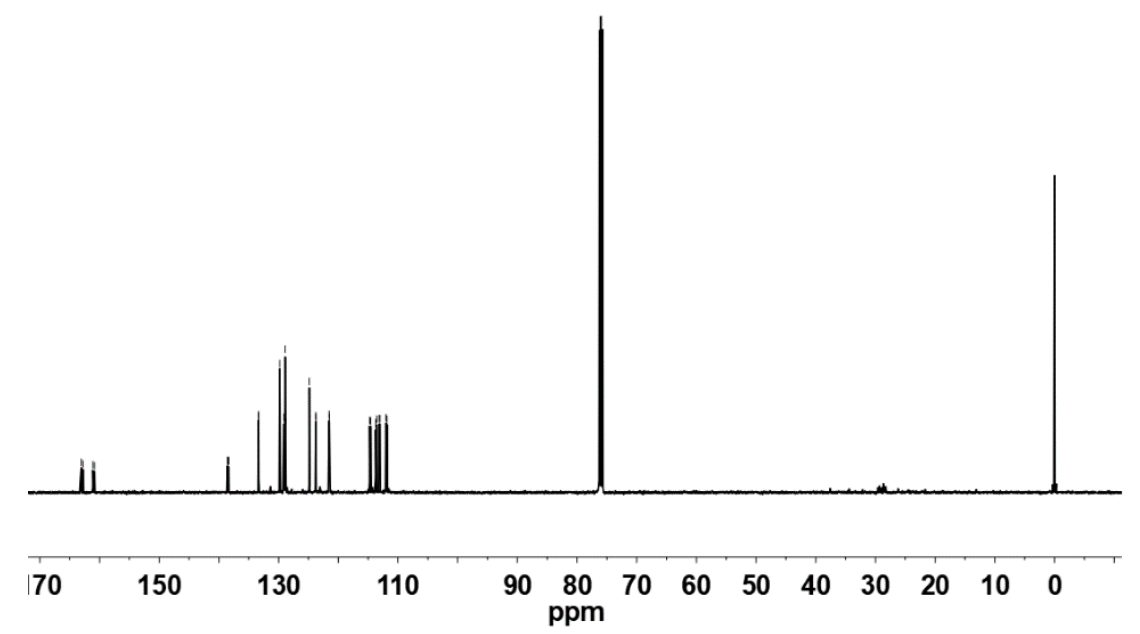

Figure S52. ${ }^{13} \mathrm{C}$ NMR spectrum of $3 \mathbf{e}$ in $\mathrm{CDCl}_{3}$. 


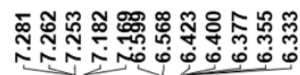
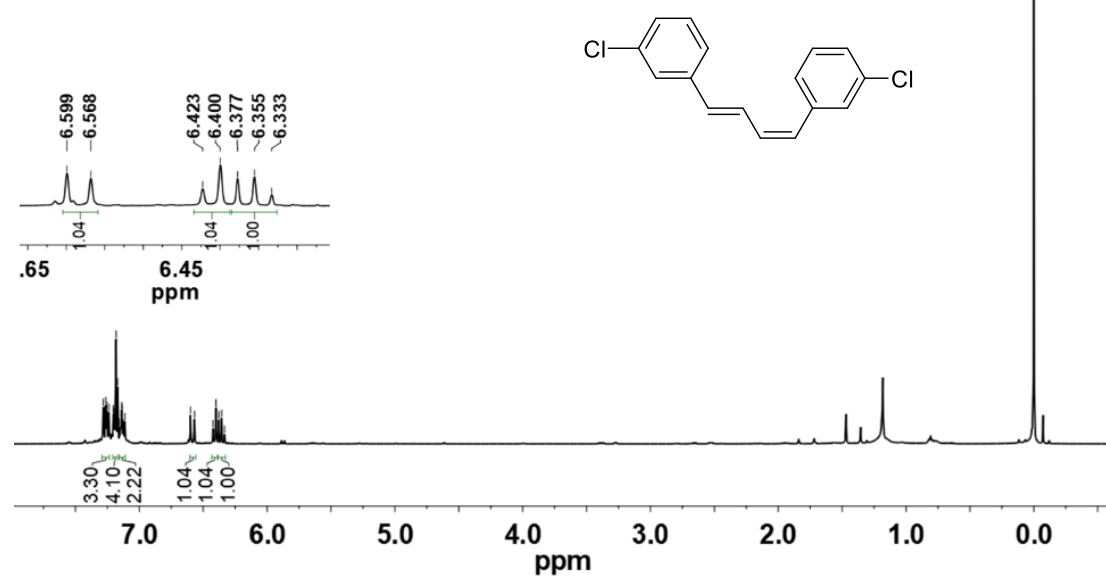

Figure S53. ${ }^{1} \mathrm{H}$ NMR spectrum of $\mathbf{3 f}$ in $\mathrm{CDCl}_{3}$.
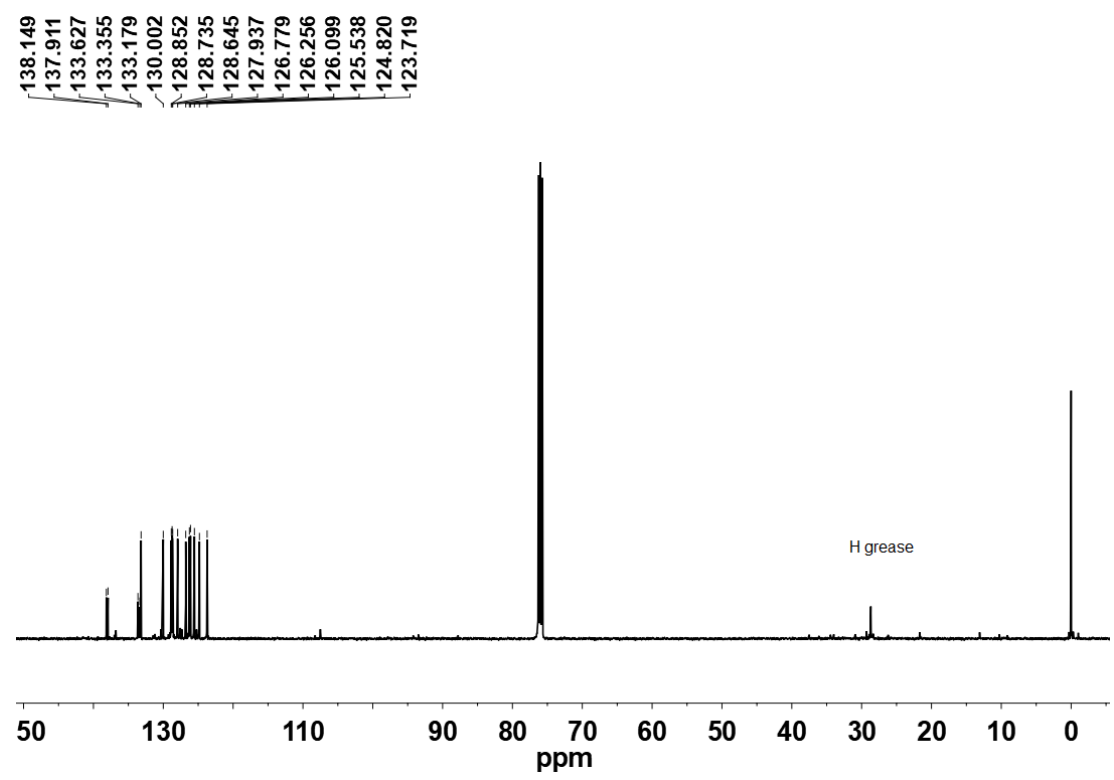

Figure S54. ${ }^{13} \mathrm{C}$ NMR spectrum of $\mathbf{3 f}$ in $\mathrm{CDCl}_{3}$. 


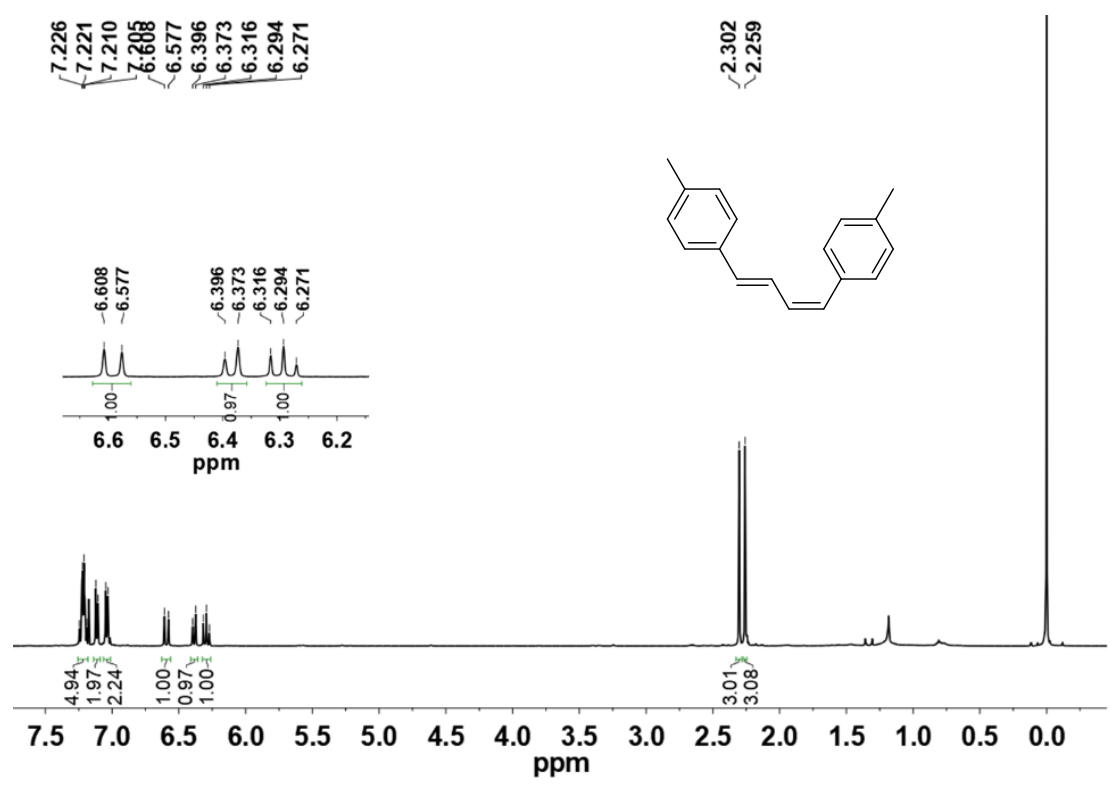

Figure S55. ${ }^{1} \mathrm{H}$ NMR spectrum of $\mathbf{3 g}$ in $\mathrm{CDCl}_{3}$.
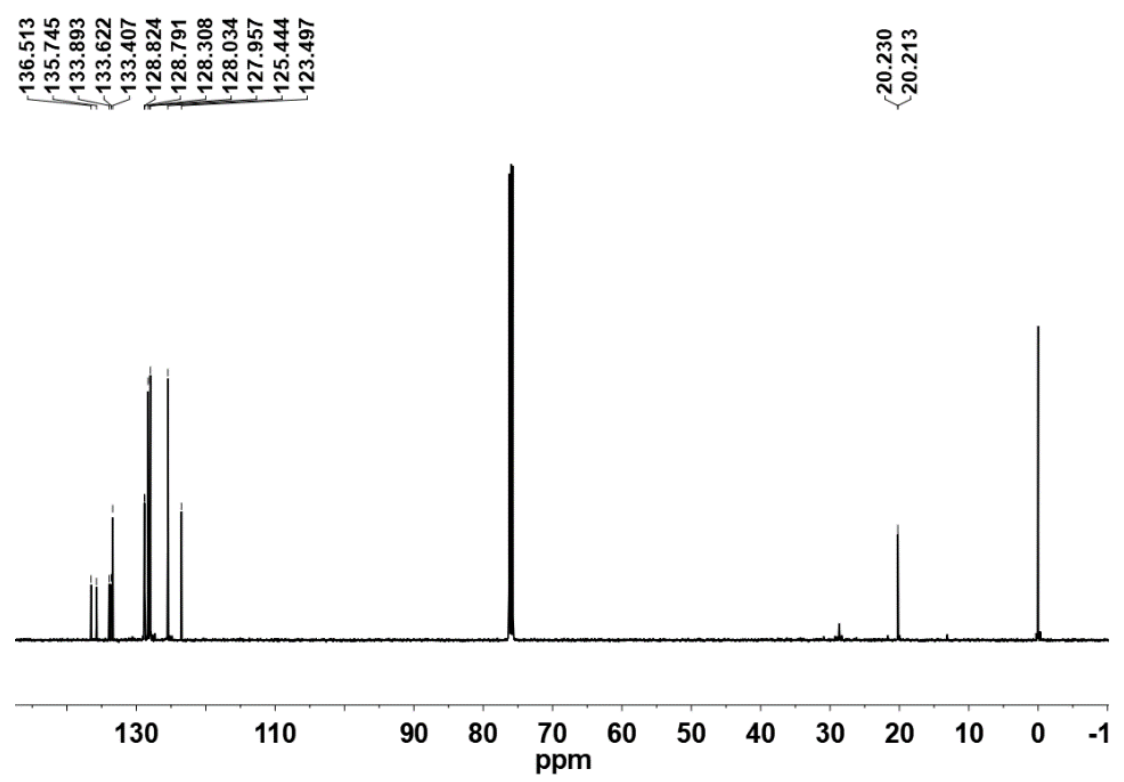

Figure S56. ${ }^{13} \mathrm{C}$ NMR spectrum of $\mathbf{3 g}$ in $\mathrm{CDCl}_{3}$ 


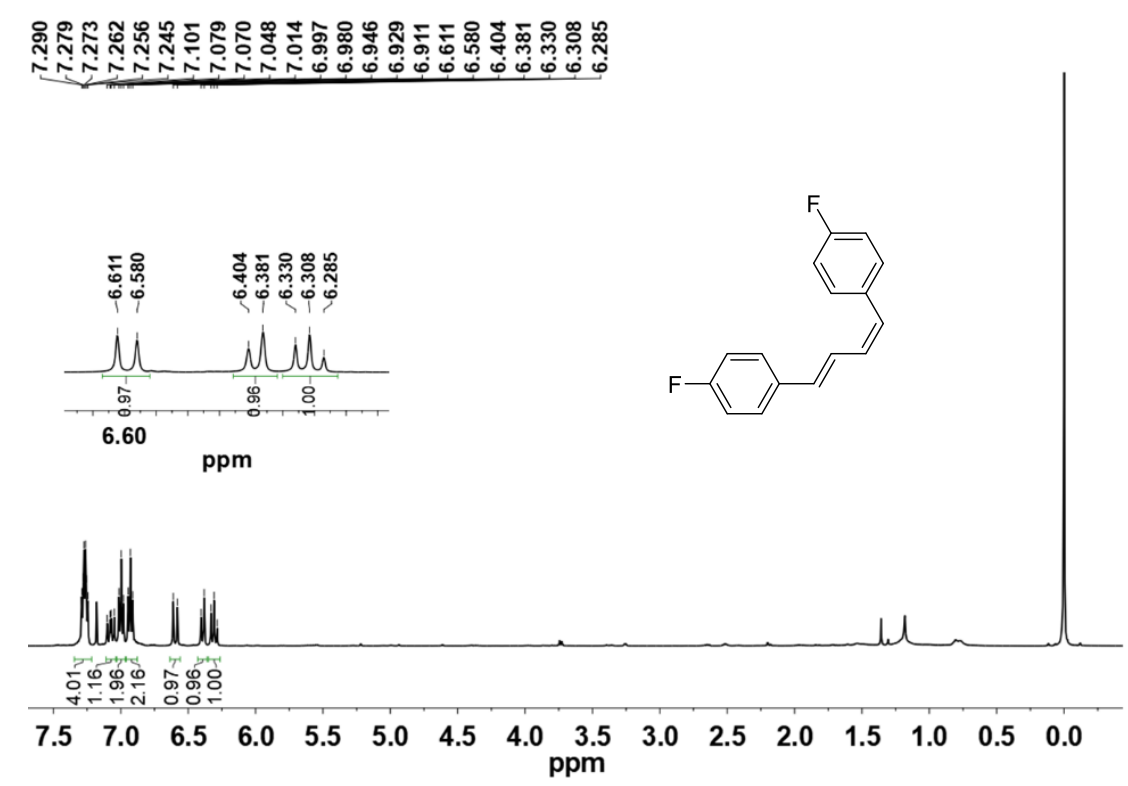

Figure S57. ${ }^{1} \mathrm{H}$ NMR spectrum of $\mathbf{3 h}$ in $\mathrm{CDCl}_{3}$.

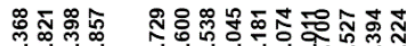 \\ ஸ்.}

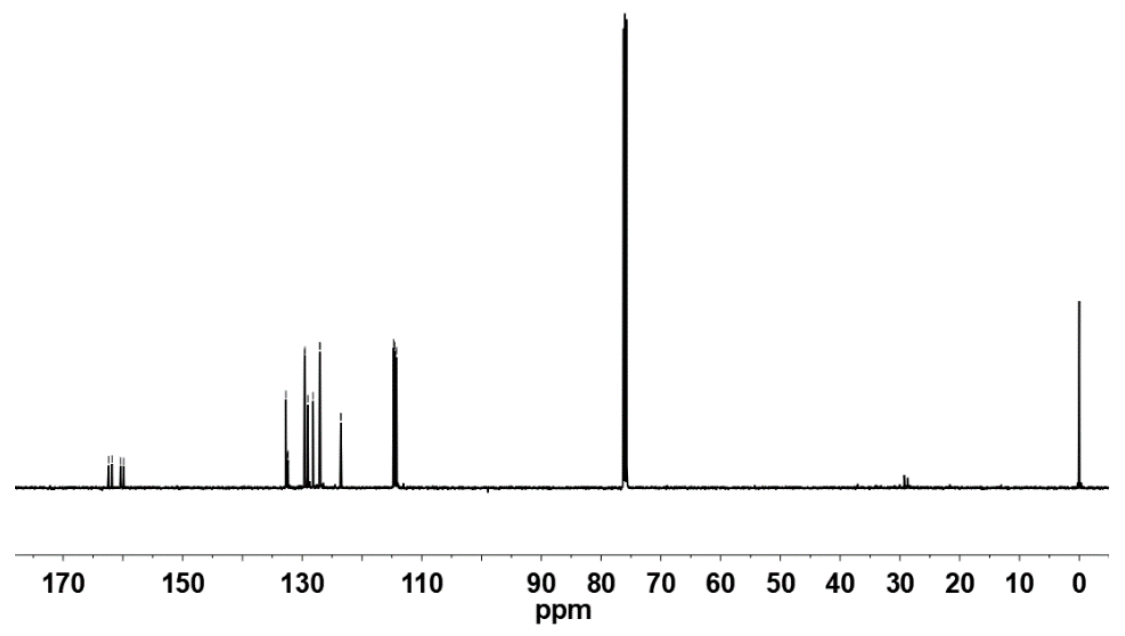

Figure S58. ${ }^{13} \mathrm{C}$ NMR spectrum of $\mathbf{3 h}$ in $\mathrm{CDCl}_{3}$. 


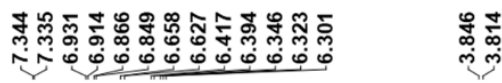

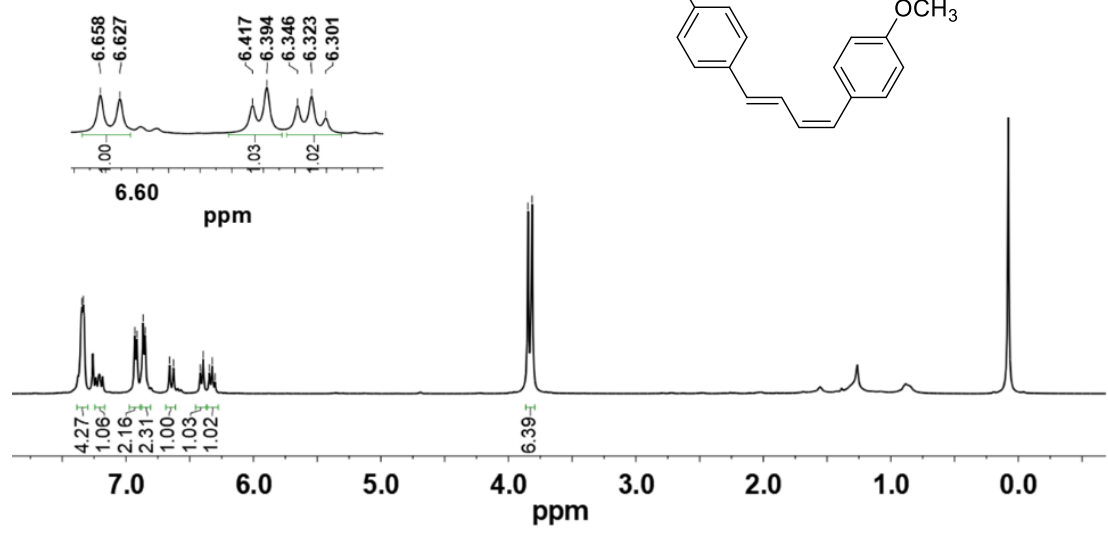

Figure S59. ${ }^{1} \mathrm{H}$ NMR spectrum of $\mathbf{3 i}$ in $\mathrm{CDCl}_{3}$.

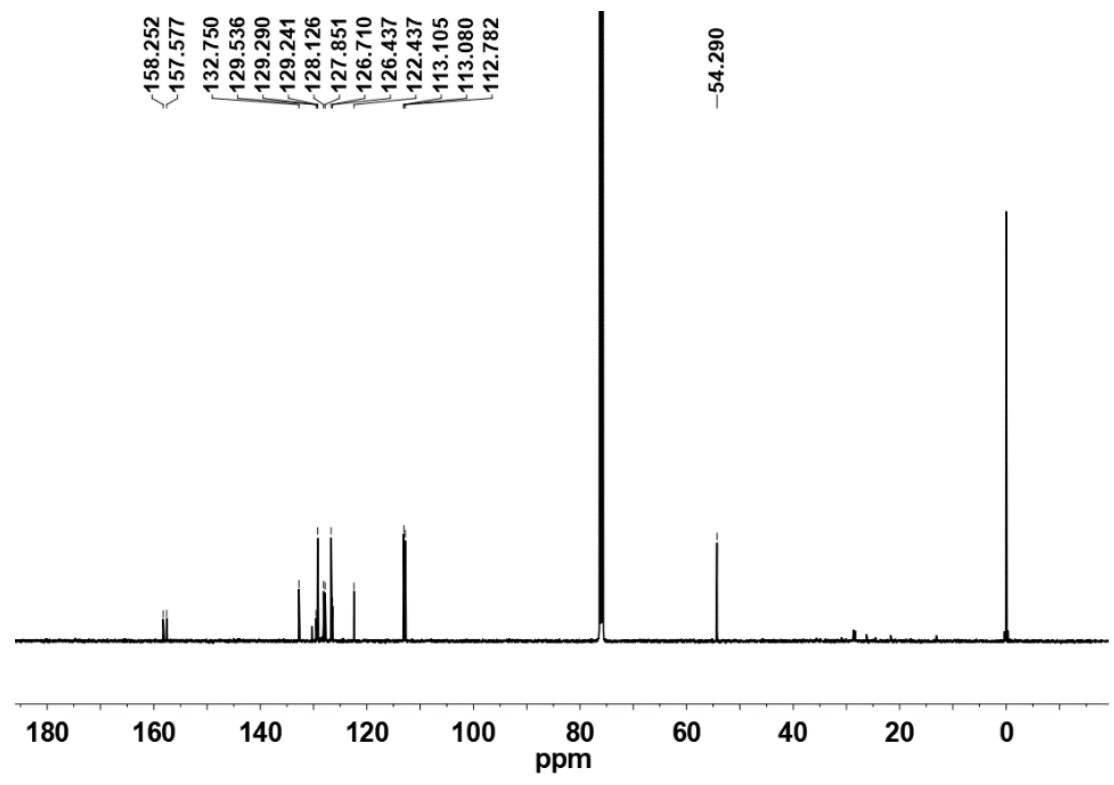

Figure S60. ${ }^{13} \mathrm{C}$ NMR spectrum of $\mathbf{3 i}$ in $\mathrm{CDCl}_{3}$. 


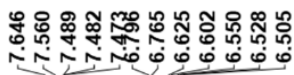
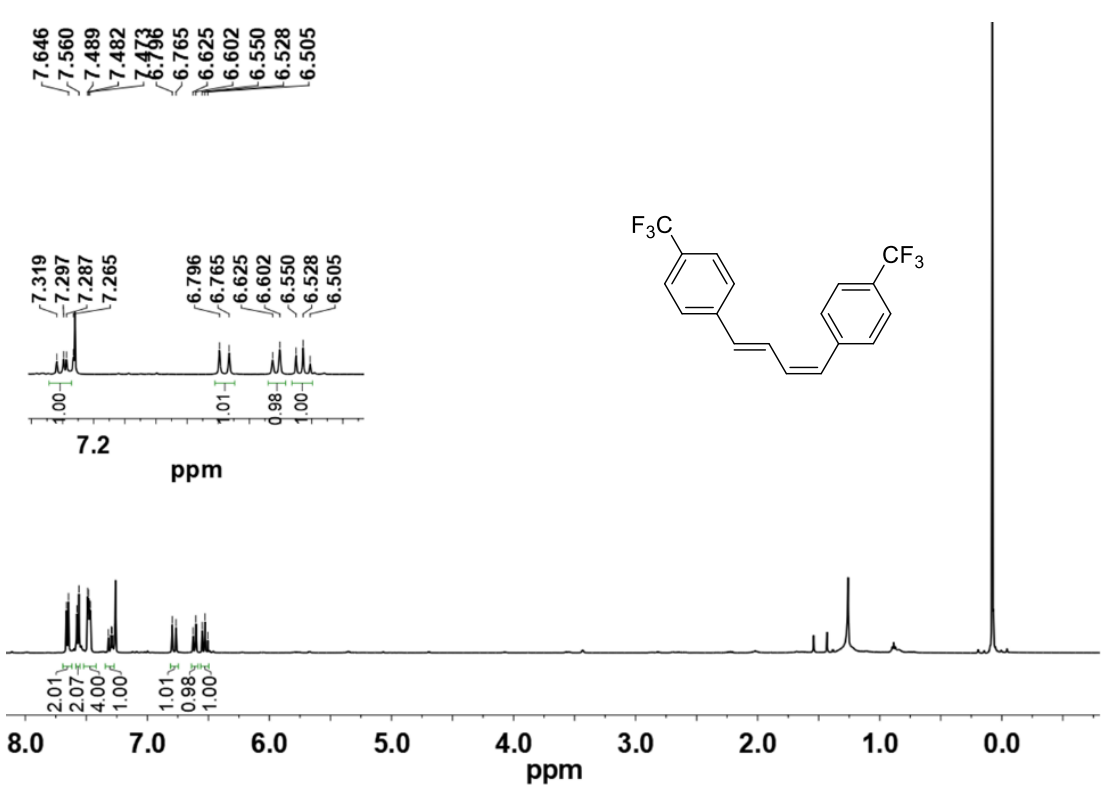

Figure S61. ${ }^{1} \mathrm{H}$ NMR spectrum of $\mathbf{3} \mathbf{j}$ in $\mathrm{CDCl}_{3}$.

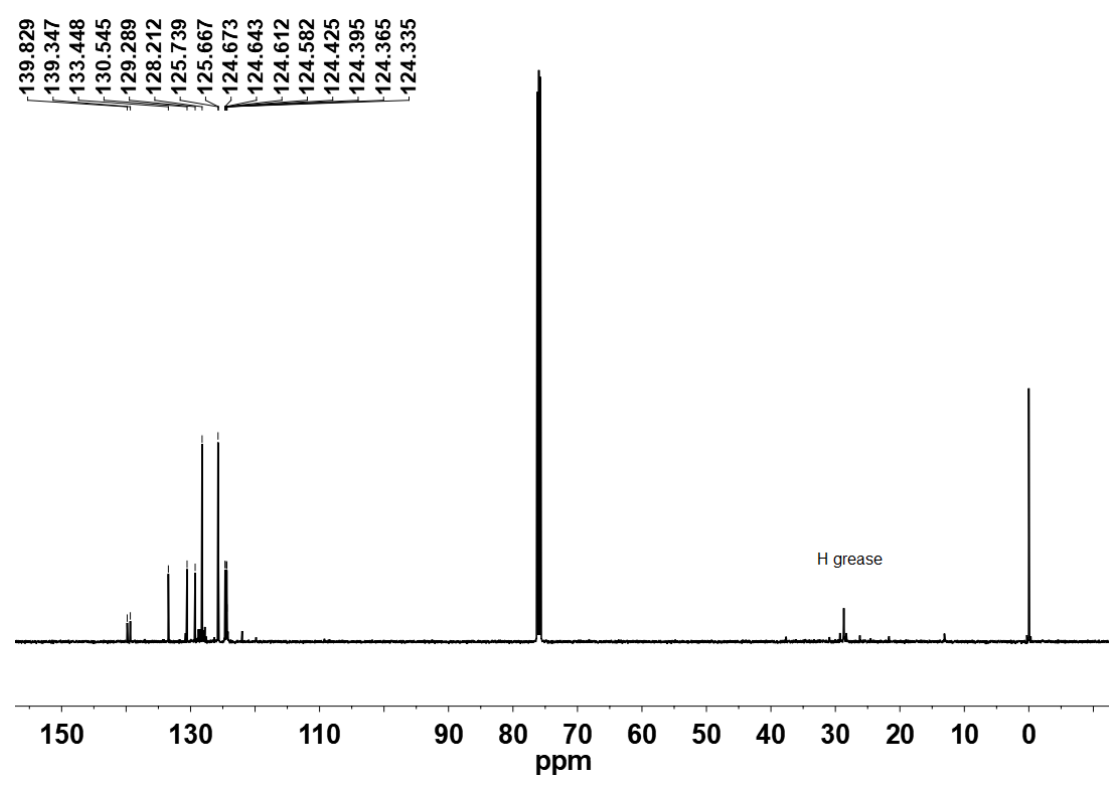

Figure S62. ${ }^{13} \mathrm{C}$ NMR spectrum of $\mathbf{3} \mathbf{j}$ in $\mathrm{CDCl}_{3}$. 


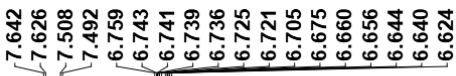

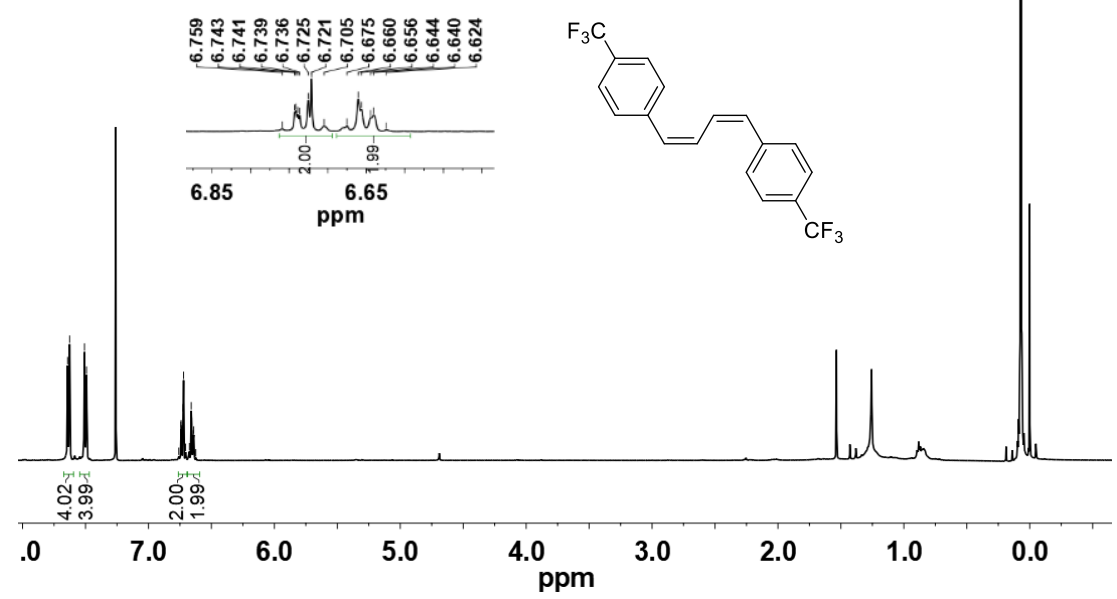

Figure S63. ${ }^{1} \mathrm{H}$ NMR spectrum of $\mathbf{3 j}$ ' in $\mathrm{CDCl}_{3}$.

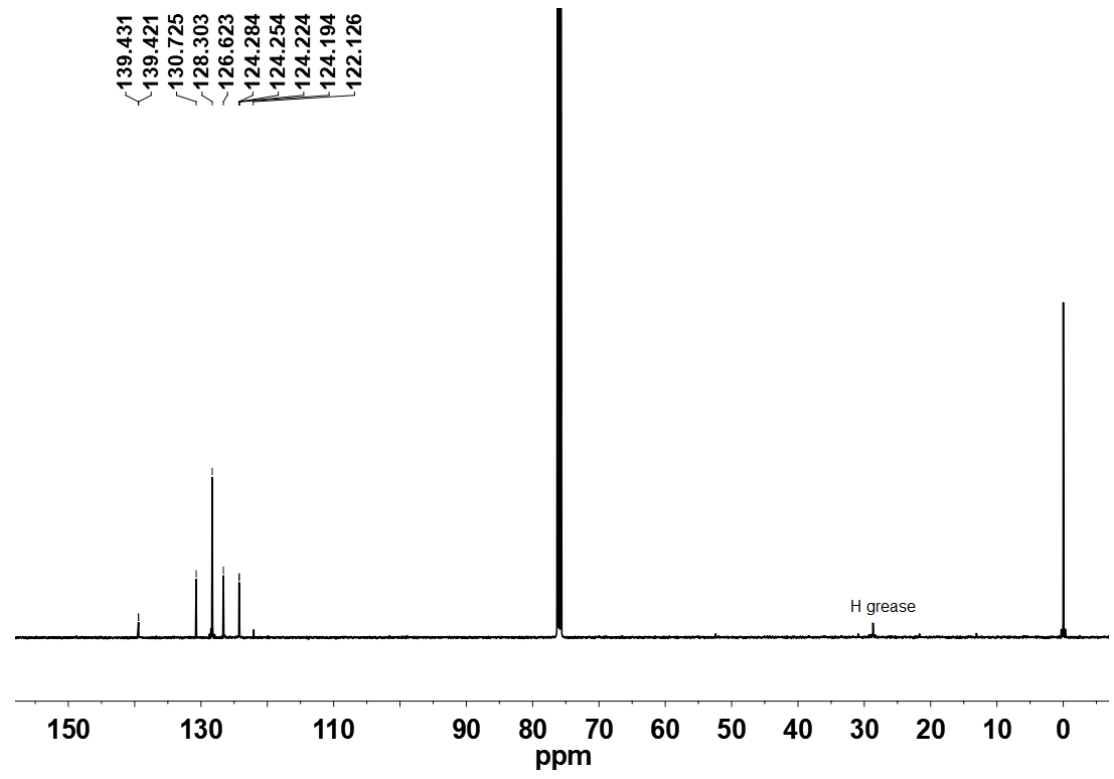

Figure S64. ${ }^{13} \mathrm{C}$ NMR spectrum of $\mathbf{3 j}$ ' in $\mathrm{CDCl}_{3}$. 


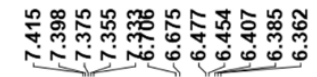
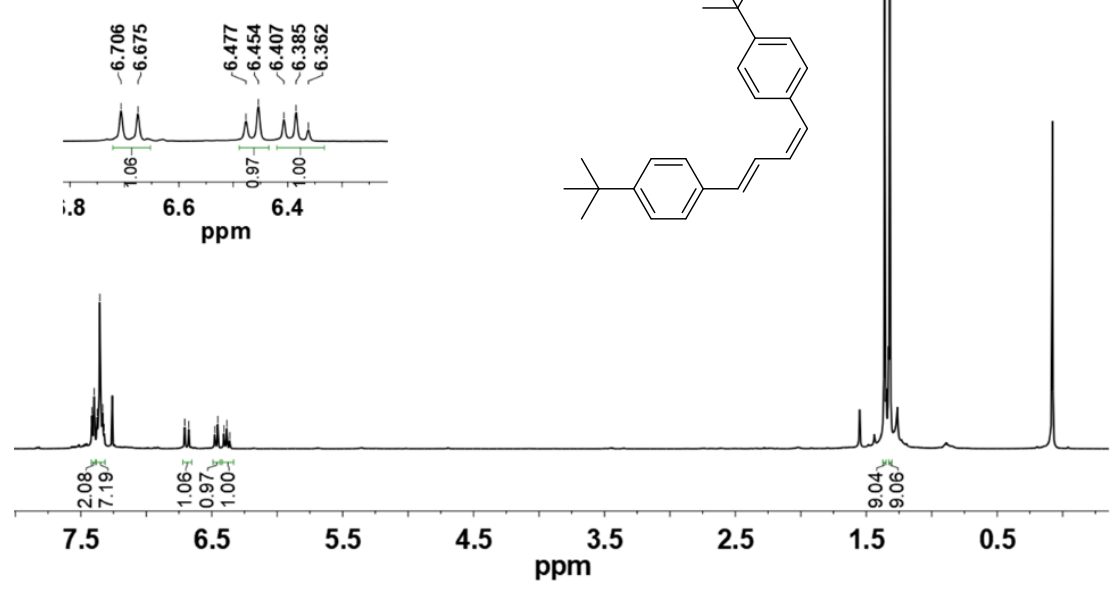

Figure S65. ${ }^{1} \mathrm{H}$ NMR spectrum of $\mathbf{3 k}$ in $\mathrm{CDCl}_{3}$.

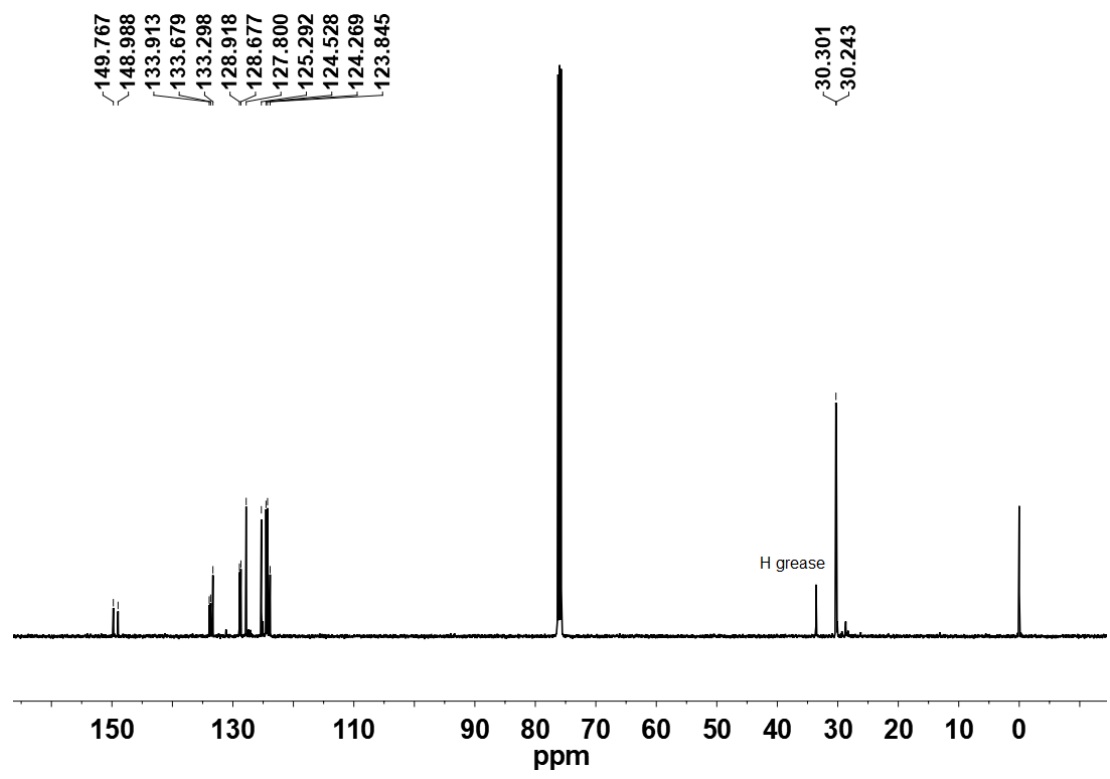

Figure S66. ${ }^{13} \mathrm{C}$ NMR spectrum of $\mathbf{3 k}$ in $\mathrm{CDCl}_{3}$

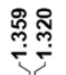
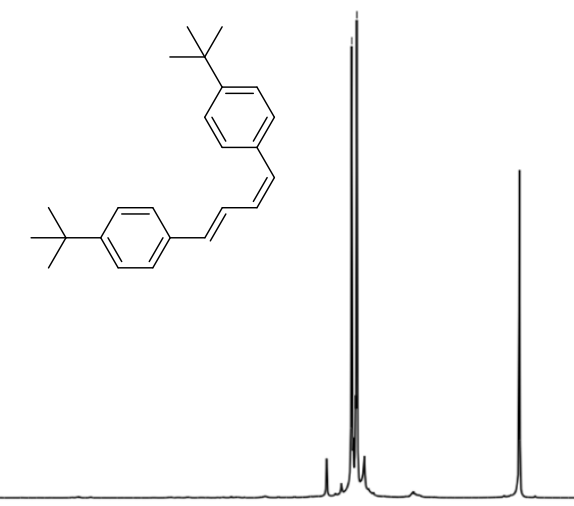

$$
\text { (1) }
$$




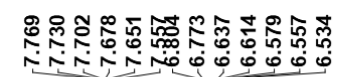

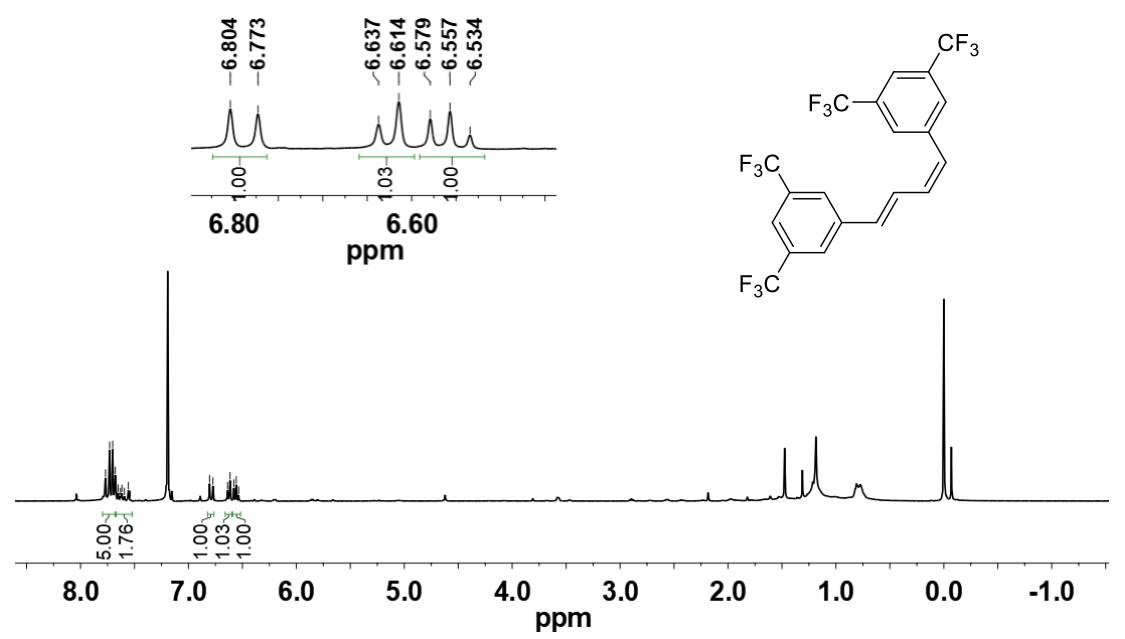

Figure S67. ${ }^{1} \mathrm{H}$ NMR spectrum of $\mathbf{3 l}$ in $\mathrm{CDCl}_{3}$.

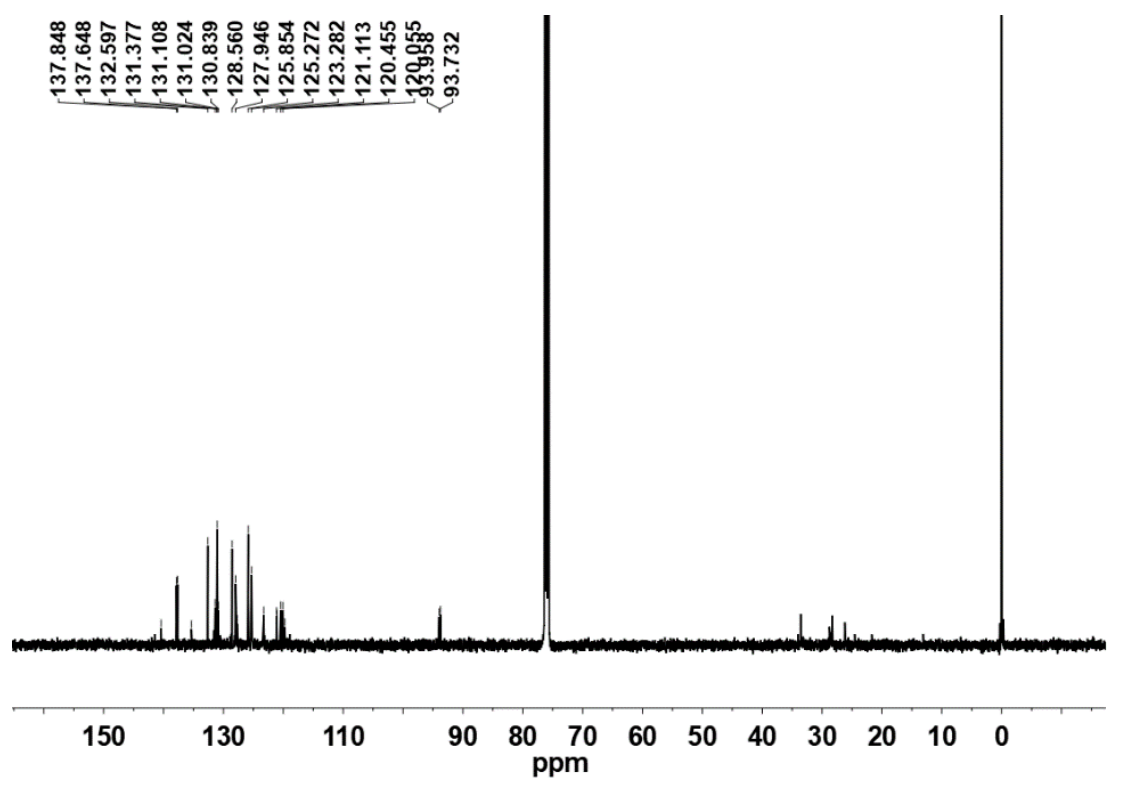

Figure S68. ${ }^{13} \mathrm{C}$ NMR spectrum of $\mathbf{3 l}$ in $\mathrm{CDCl}_{3}$. 


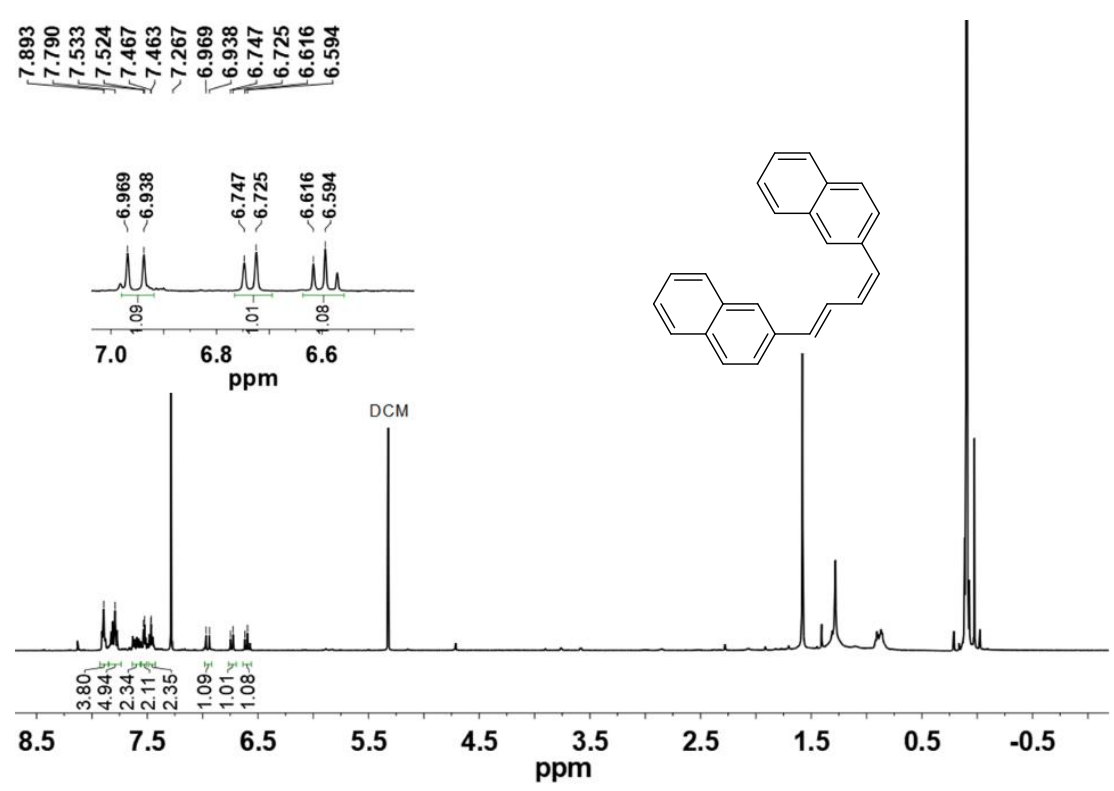

Figure S69. ${ }^{1} \mathrm{H}$ NMR spectrum of $\mathbf{3 m}$ in $\mathrm{CDCl}_{3}$.

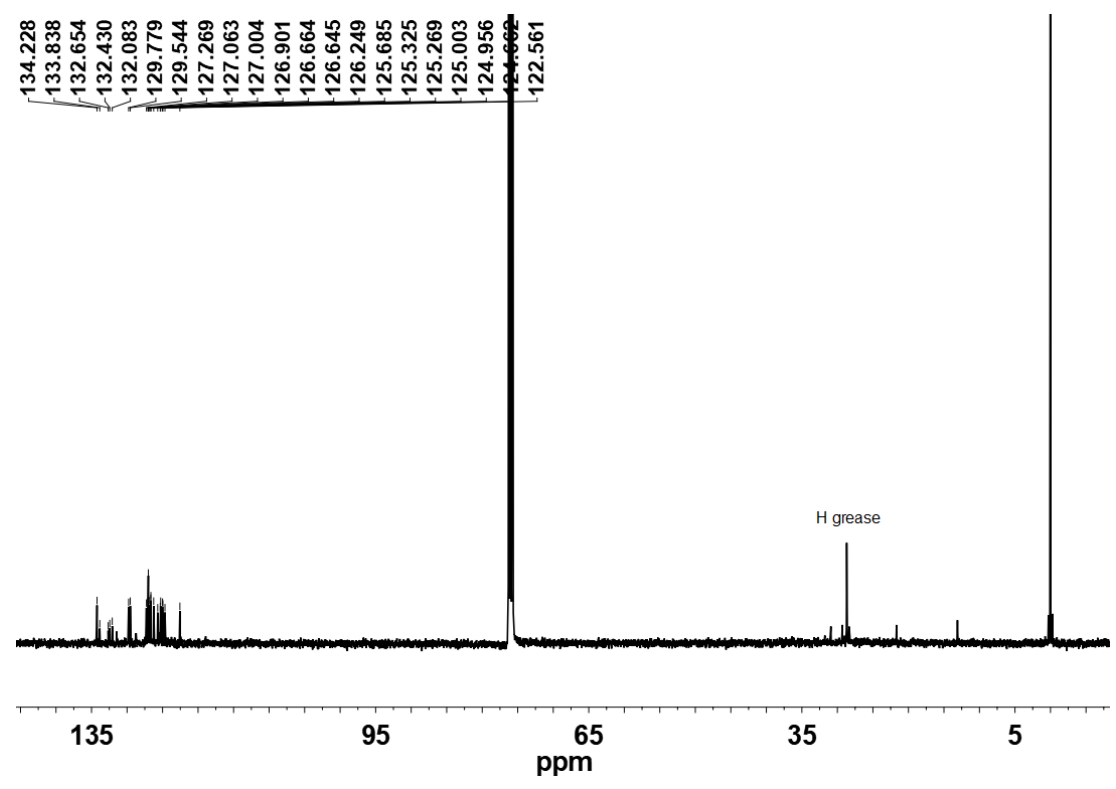

Figure S70. ${ }^{13} \mathrm{C}$ NMR spectrum of $\mathbf{3 m}$ in $\mathrm{CDCl}_{3}$. 


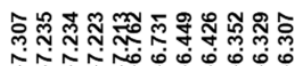
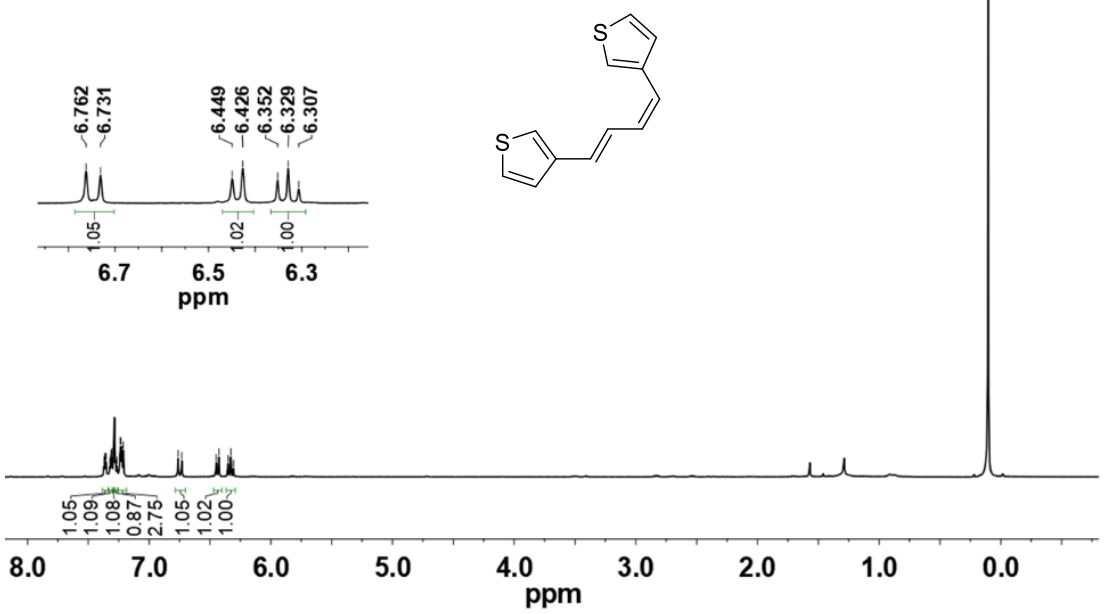

Figure S71. ${ }^{1} \mathrm{H}$ NMR spectrum of $\mathbf{3 n}$ in $\mathrm{CDCl}_{3}$.
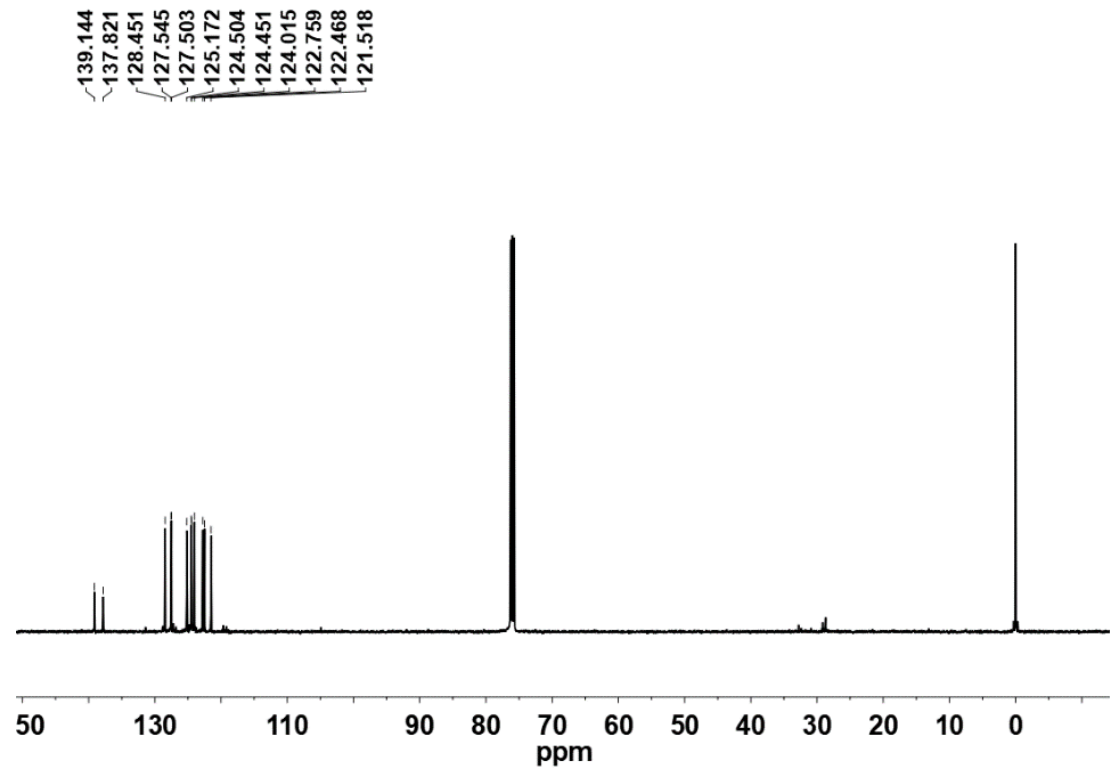

Figure S72. ${ }^{13} \mathrm{C}$ NMR spectrum of $\mathbf{3 n}$ in $\mathrm{CDCl}_{3}$. 


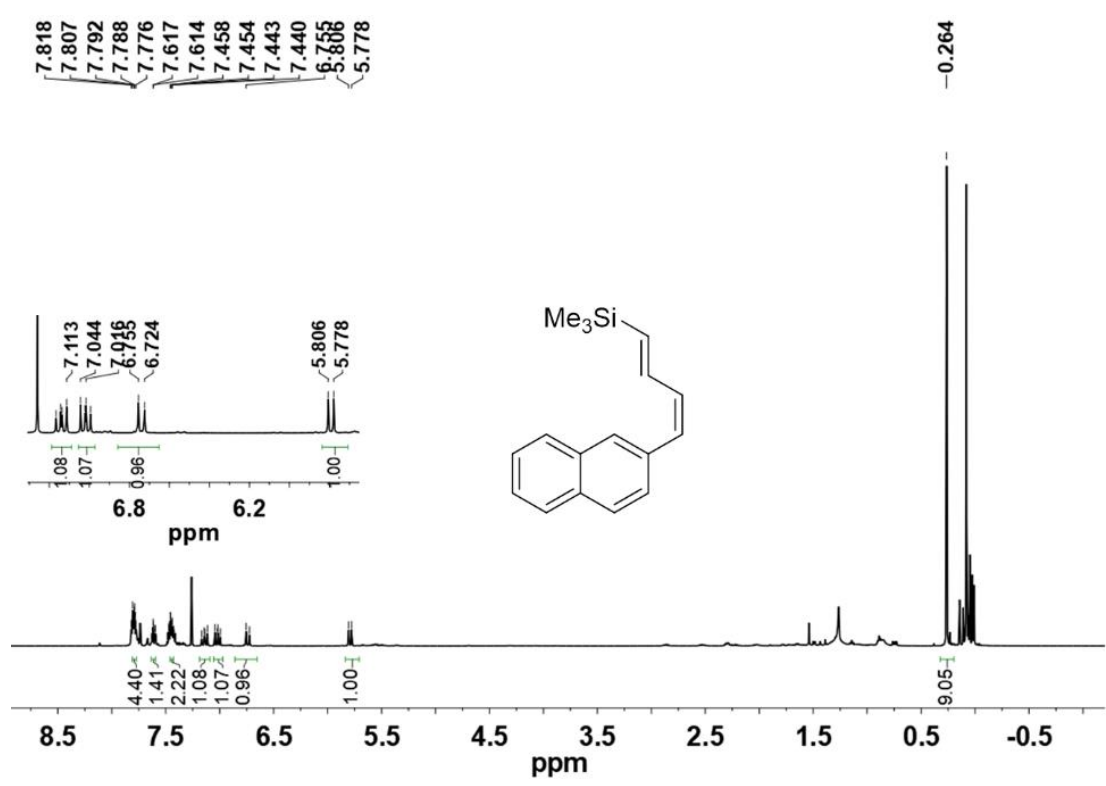

Figure S73. ${ }^{1} \mathrm{H}$ NMR spectrum of $\mathbf{3 o}$ in $\mathrm{CDCl}_{3}$.

\section{X -ray Data}

Table S3. Crystal data and structure refinement of 1, 4 and $\mathbf{5 m}$

\begin{tabular}{|c|c|c|c|}
\hline & 1 & 4 & $5 \mathrm{~m}$ \\
\hline Empirical formula & $\mathrm{C}_{64} \mathrm{H}_{80} \mathrm{Co}_{2} \mathrm{~N}_{2} \mathrm{O}_{4} \mathrm{P}_{2}$ & $\mathrm{C}_{37} \mathrm{H}_{38} \mathrm{CoNO}_{2} \mathrm{P}$ & $\mathrm{C}_{24} \mathrm{H}_{16}$ \\
\hline Formula weight & 1121.10 & 618.58 & 304.37 \\
\hline Temperature/K & $173.00(10)$ & 293(2) & $173.00(10)$ \\
\hline Crystal system & triclinic & monoclinic & monoclinic \\
\hline Space group & $\mathrm{P}-1$ & $\mathrm{P} 2{ }_{1}$ & $\mathrm{P} 2{ }_{1} / \mathrm{n}$ \\
\hline $\mathrm{a} / \AA ̊$ & $11.8771(5)$ & $9.82669(19)$ & $5.9894(2)$ \\
\hline $\mathrm{b} / \AA$ & $15.1866(6)$ & 13.1968(3) & $7.3642(3)$ \\
\hline $\mathrm{c} / \AA ̊$ & $16.6084(8)$ & $12.3581(2)$ & $36.2572(15)$ \\
\hline$\alpha /^{\circ}$ & $80.467(4)$ & 90 & 90 \\
\hline$\beta /^{\circ}$ & $89.333(4)$ & $93.6955(18)$ & $91.179(3)$ \\
\hline$\gamma /{ }^{\circ}$ & $87.615(4)$ & 90 & 90 \\
\hline Volume $/ \AA^{3}$ & $2951.7(2)$ & $1599.28(6)$ & $1598.86(11)$ \\
\hline $\mathrm{Z}$ & 2 & 2 & 4 \\
\hline$\rho_{\text {calc }} / \mathrm{cm}^{3}$ & 1.261 & 1.285 & 1.264 \\
\hline$\mu / \mathrm{mm}^{-1}$ & 5.280 & 0.620 & 0.542 \\
\hline $\mathrm{F}(000)$ & 1188.0 & 650.0 & 640.0 \\
\hline Radiation & $\mathrm{CuK} \alpha(\lambda=1.54184)$ & $\operatorname{MoK} \alpha(\lambda=0.710)$ & $\mathrm{CuK} \alpha(\lambda=1.54184)$ \\
\hline $\begin{array}{l}2 \Theta \text { range for data } \\
\text { collection }^{\circ}\end{array}$ & 7.314 to 154.806 & 3.3 to 50.186 & 9.76 to 134.108 \\
\hline Index ranges & $\begin{array}{l}-12 \leq \mathrm{h} \leq 14 \\
-19 \leq \mathrm{k} \leq 19\end{array}$ & $\begin{array}{c}-9 \leq \mathrm{h} \leq 11 \\
-13 \leq \mathrm{k} \leq 15\end{array}$ & $\begin{array}{l}-5 \leq \mathrm{h} \leq 7 \\
-8 \leq \mathrm{k} \leq 8\end{array}$ \\
\hline
\end{tabular}




\section{Supporting Information}

\begin{tabular}{|c|c|c|c|}
\hline & $-20 \leq 1 \leq 20$ & $-14 \leq 1 \leq 14$ & $-43 \leq 1 \leq 43$ \\
\hline Reflections collected & 31544 & 9291 & 7270 \\
\hline $\begin{array}{c}\text { Independent } \\
\text { reflections }\end{array}$ & $\begin{array}{c}11679 \\
{\left[\mathrm{R}_{\text {int }}=0.0593,\right.} \\
\left.\mathrm{R}_{\text {sigma }}=0.0641\right]\end{array}$ & $\begin{array}{c}4535 \\
{\left[\mathrm{R}_{\text {int }}=0.0433,\right.} \\
\left.\mathrm{R}_{\text {sigma }}=0.0524\right]\end{array}$ & $\begin{array}{c}2794 \\
{\left[\mathrm{R}_{\text {int }}=0.0586,\right.} \\
\left.\mathrm{R}_{\text {sigma }}=0.0645\right]\end{array}$ \\
\hline $\begin{array}{c}\text { Data/restraints/param } \\
\text { eters }\end{array}$ & $11679 / 0 / 681$ & $4535 / 2 / 385$ & $2794 / 0 / 235$ \\
\hline Goodness-of-fit on $\mathrm{F}^{2}$ & 1.087 & 1.044 & 1.057 \\
\hline $\begin{array}{c}\text { Final R indexes } \\
{[\mathrm{I}>=2 \sigma(\mathrm{I})]}\end{array}$ & $\begin{array}{c}\mathrm{R}_{1}=0.0541, \\
\mathrm{wR} 2=0.1036\end{array}$ & $\begin{array}{c}\mathrm{R}_{1}=0.0730, \\
\mathrm{wR} 2=0.1701\end{array}$ & $\begin{array}{c}\mathrm{R}_{1}=0.0857, \\
\mathrm{wR}_{2}=0.2262\end{array}$ \\
\hline $\begin{array}{c}\text { Final R indexes [all } \\
\text { data] }\end{array}$ & $\mathrm{R}_{1}=0.0796$, & $\mathrm{R}_{2}=0.0856$, & $\mathrm{R}_{1}=0.1192$, \\
$\mathrm{w} \mathrm{R}_{2}=0.1256$ & $\mathrm{wR}_{2}=0.1882$ & $\mathrm{wR}_{2}=0.2482$ \\
\hline $\begin{array}{c}\text { Largest diff. } \\
\text { peak/hole/e } \AA^{-3}\end{array}$ & $0.41 /-0.47$ & $0.60 /-0.92$ & $0.33 /-0.39$ \\
\hline
\end{tabular}

\section{Reference}

(1) Jiang, F.; Achard, M.; Roisnel, T.; Dorcet, V.; Bruneau, C. Eur. J. Inorg. Chem. 2015, 2015, 4312 .

(2) Palatinus, L.; Chapuis, G. J. Appl. Crystallogr. 2007, 40, 786.

(3) Sheldrick, G. M. Acta Crystallogr. Sect. C 2015, 71, 3.

(4) Dolomanov, O. V.; Bourhis, L. J.; Gildea, R. J.; Howard, J. A. K.; Puschmann, H. J. Appl. Crystallogr. 2009, 42, 339.

(5) Spek, A. L. Acta Crystallogr. Sect. D 2009, 65, 148.

(6) Frisch, M. J.; Trucks, G. W.; Schlegel, H. B.; Scuseria, G. E.; M. A.; Robb, Cheeseman, J. R.; Scalmani, G.; Barone, V.; Mennucci, B.; Petersson, G. A.; Nakatsuji, H.; Caricato, M.; Li, X.; Hratchian, H. P.; Izmaylov, A. F.; Bloino, J.; Zheng, G.; Sonnenberg, J. L.; Hada, M.; Ehara, M.; Toyota, K.; Fukuda, R.; Hasegawa, J.; Ishida, M.; Nakajima, T.; Honda, Y.; Kitao, O.; Nakai, H.; Vreven, T.; Montgomery, J. A. Jr.; Peralta, J. E.; Ogliaro, F.; Bearpark, M.; Heyd, J. J.; Brothers, E.; Kudin, K. N.; Staroverov, V. N.; Kobayashi, R.; Normand, J.; Raghavachari, K.; Rendell, A.; Burant, J. C.; Iyengar, S. S.; Tomasi, J.; Cossi, M.; Rega, N.; Millam, M. J.; Klene, M.; Knox, J. E.; Cross, J. B.; Bakken, V.; Adamo, C.; Jaramillo, J.; Gomperts, R.; Stratmann, R. E.; Yazyev, O.; Austin, A. J.; Cammi, R.; Pomelli, C.; Ochterski, J. W.; Martin, R. L.; Morokuma, K.; Zakrzewski, V. G.; Voth, G. A.; 


\section{Supporting Information}

Salvador, P.; Dannenberg, J. J.; Dapprich, S.; Daniels, A. D.; Farkas, O.; Foresman, J.

B.; Ortiz, J. V.; Cioslowski, J.; Fox, D. J.; Gaussian 09, Revision D. 01; Gaussian, Inc.: Wallingford CT, 2013.

(7) Becke, A. D. J. Chem. Phys. 1993, 98, 5648.

(8) Grimme, S.; Antony, J.; Ehrlich, S.; Krieg, H. J. Chem. Phys. 2010, 132, 154104.

(9) Dolg, M.; Wedig, U.; Stoll, H.; Preuss, H. J. Chem. Phys. 1987, 86, 866.

(10) Marenich, A. V.; Cramer, C. J.; Truhlar, D. G. J. Phys. Chem. B 2009, 113, 6378.

(11) Reiher, M.; Salomon, O.; Hess, B. A. Theor. Chem. Acc. 2001, 107, 48.

(12) Salomon, O.; Reiher, M.; Hess, B. A. J. Chem. Phys. 2002, 117, 4729.

(13) Neese, F. Coord. Chem. Rev. 2009, 253, 526.

(14) Blomberg, M. R. A.; Borowski, T.; Himo, F.; Liao, R.-Z. Chem. Rev. 2014, 114, 3601.

(15) Marenich, A. V.; Ho, J.; Coote, M.; Cramer, C. J.; Truhlar, D. G. Phys. Chem. Chem. Phys. 2014, 16, 15068.

(16) Rubio-Perez, L.; Azpiroz, Giuseppe, R.; A. D.; Polo, V.; Castarlenas, R.;

Perez-Torrente, J.J.; Oro L. A. Chem. Eur. J. 2013, 19, 15304.

(17) Zatolochnaya, O.V.; Gordeev, E. G.; Jahier, C.; Ananikov, V. P.; Gevorgyan, V. Chem. Eur. J. 2014, 20, 9578.

(18) Midya, G. C.; Paladhi, S.; Dhara, K.; Dash, J. Chem. Commun. 2011, 47, 6698.

(19) Rubina, M.; Gevorgyan, V. J. Am. Chem. Soc. 2001, 123, 11107.

(20) Bhunia, M.; Sahoo, S.R.; Vijaykumar, G.; Adhikari, D.; Mandal, S. K.

Organometallics 2016, 35, 3775.

(21) Yang, L.; Liu, R. S. H.; Boarman, K. J.; Wendt, N. L.; Liu, J.; J. Am. Chem. Soc. 2005, 127, 2404.

(22) Wilklow-Marnell, M.; Li, B.; Zhou, T.; Krogh-Jespersen, K.; Brennessel, W. W.;

Emge, T. J.; Jones, W. D. J. Am. Chem. Soc. 2017, 139, 8977. 